\title{
Revision of the Spider Mite Family Tetranychidae of Japan (Acari, Prostigmata)
}

\author{
Shôzô Ehara \\ Hamasaka 2-15-7, Tottori 680-0001, Japan
}

(Received 22 December 1997; Accepted 31 July 1998)

\begin{abstract}
A total of 78 Japanese species belonging to the family Tetranychidae (spider mites) are assigned to two subfamilies, five tribes, 16 genera, and 13 species groups (only in four genera). A guide to identification of the Japanese species is provided, and information is also given about the important literature references, host plants, and distribution of each species. Three new species, Eotetranychus rubricans, Oligonychus gotohi, and Tetranychus parakanzawai are described. Eotetranychus lewisi (McGregor), recently recorded from Japan, is redescribed. Key Words: classification, fauna, host plants, Japan, keys, new species, spider mites, Tetranychidae.
\end{abstract}

\section{Introduction}

All spider mites, constituting the family Tetranychidae, are obligatory plant feeders, and many of them are ranked as very important pests of agricultural and ornamental plants. Because of their ecomomic importance, the tetranychids have much been studied in the fields of taxonomy, biology, ecology, cytology, genetics, biochemistry, etc. throughout the world. Early valuable contributions to the taxonomy of Tetranychidae were made by Oudemans, Zacher, Hirst, and Geijskes in Europe, and by Banks, Ewing, and McGregor in the U.S.A. Since 1950 some major monographs of tetranychids have been published: McGregor (1950), Pritchard and Baker (1955), Reck (1959), Wainstein (1960), Tuttle and Baker (1968), Meyer (1974, 1987), Wang (1981), Baker and Tuttle (1994), and Bolland et al. (1998). Other important works have been published in many parts of the world.

With respect to the taxonomy of Japanese tetranychids, a few important articles were early published (Kishida 1927; Yokoyama 1929, 1932; Yokoyama and Ishii 1934). Since Ehara (1954) Japanese tetranychid species have been studied extensively by the author and his co-workers. Seventy-five species of tetranychids have hitherto been reported from Japan.

In the present taxonomic revision the 78 species now known in this country are divided into subfamilies, tribes, genera, and species groups, with keys and illustrations of diagnostic characters. The type locality of each species is given in parentheses following the citation of the original description. For every species, important references (redescriptions, etc.) and information on the host plants and distribution are also included.

The type series of all the Japanese tetranychid species that were previously described by the author, as well as the new species described herein, are now preserved in the Department of Biology, Faculty of Education and Regional Sciences, Tottori University, Tottori. However, at least the holotypes will be deposited in the 
National Science Museum, Tokyo, in the near future.

\section{Terminology and Diagnostic Characters}

The measurements are in micrometers (' $\mu \mathrm{m}$ ' often being omitted in the text), and those of the holotypes of the new species are given in parentheses following the mean \pm S.E.

The tetranychid body is divided into the gnathosoma and idiosoma, and the latter is dorsally subdivided into the prodorsum and the opisthosomal dorsum, and ventrally into the podosomal venter and the opisthosomal venter (Lindquist 1985; Gutierrz 1985). In most cases, the identification of tetranychid species is based on the adult mites. The chaetotaxy of the idiosoma is very important for determination of higher categories. The setal nomenclature varies among authors (Geijskes 1939; Grandjean 1939, 1947; Pritchard and Baker 1955; Lindquist 1985; Gutierrez 1985). The setal terms for the Tetranychinae, used in this revision resemble those of Ehara and Tho (1988), but the terms for the Bryobiinae are newly proposed (Figs 1,3). The
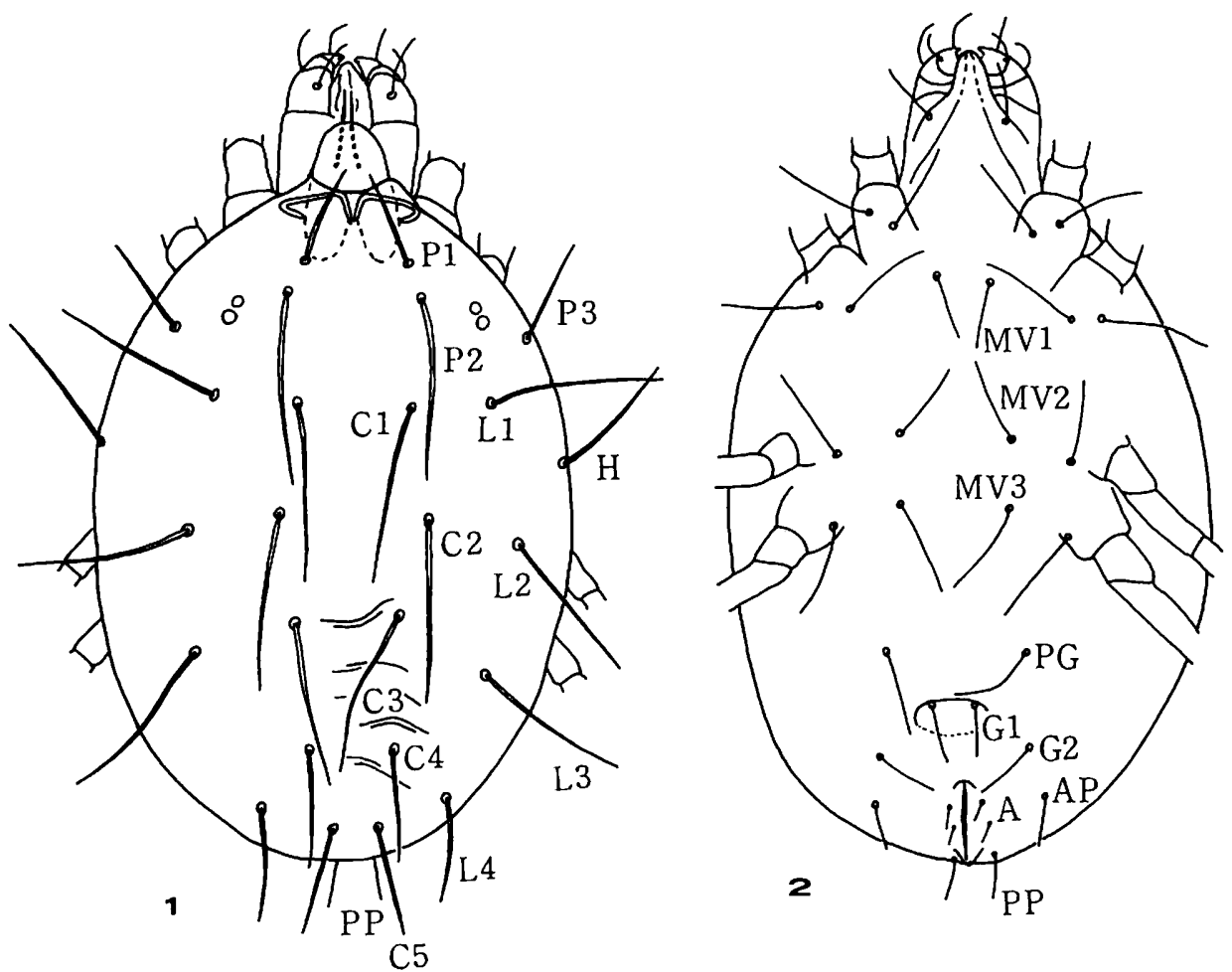

Figs 1, 2. Eotetranychus sp. (ㅇ), showing the nomenclature of the idiosomal setae. 1, dorsum; 2, venter. A, anal setae; AP, anterior para-anal setae; C1-C5, dorsocentral opisthosomal setae; G1-G2, genital setae; H, humeral setae; L1-L4, dorsolateral opisthosomal setae; MV1-MV3, medioventral setae; P1-P3, prodorsal setae; PG, pregenital setae; PP, posterior para-anal setae. 


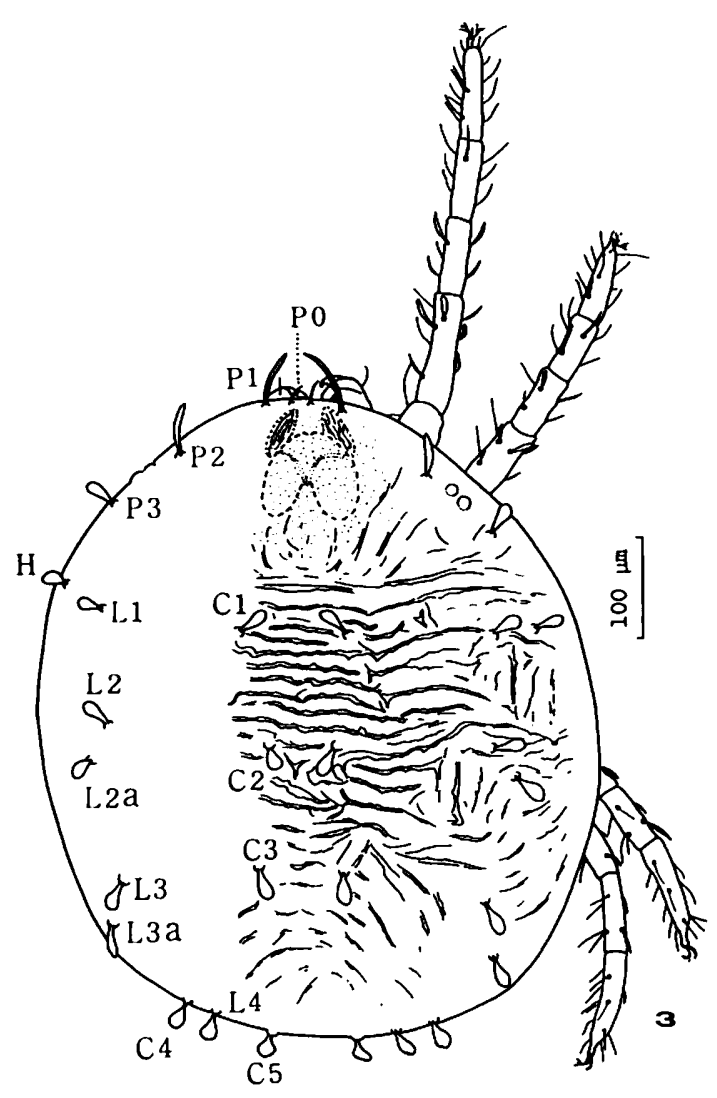

Fig. 3. Pseudobryobia japonica ( + ), dorsum, showing the nomenclature of the idiosomal setae. L1, L2, L2a, L3, L3a, L4, dorsolateral opisthosomal setae; P0, P1, P2, P3, prodorsal setae. For other abbreviations see Fig. 1.

terminology of the ventral setae is mainly based on Gutierrez (1985) (Fig. 2). The shape of the pregenital setae may be useful for species recognition (Figs 123, 124) (Ehara 1964). All of the dorsal and ventral setae on the idiosoma in tetranychids are ordinary tactile setae (Figs 4,24 ).

The pattern of the dorsal integumentary striations may be of significance for identification. Furthermore, the lobes on the dorsal opisthosomal striae have sometimes been used for species determination of summer females (e.g., Tetranychus ) (Figs 14,15), but it is rather usual for the shape of the lobes to vary considerably even within the same portion of the same individual. The striations of the genital flap and of the area immediately anterior to the flap are particularly important in separating females of the Tetranychinae. The structure of the peritremes is an important character for identification of tetranychids (Figs 5, 6); however, it should be remembered that it varies considerably among different specimens of the same species (e.g., Düzgünes, 1965).

In the Tetranychinae the palpus is furnished with a conspicuous rod-like organ at the tip of the distal segment (Figs 7,8 ). This organ was formerly called the 


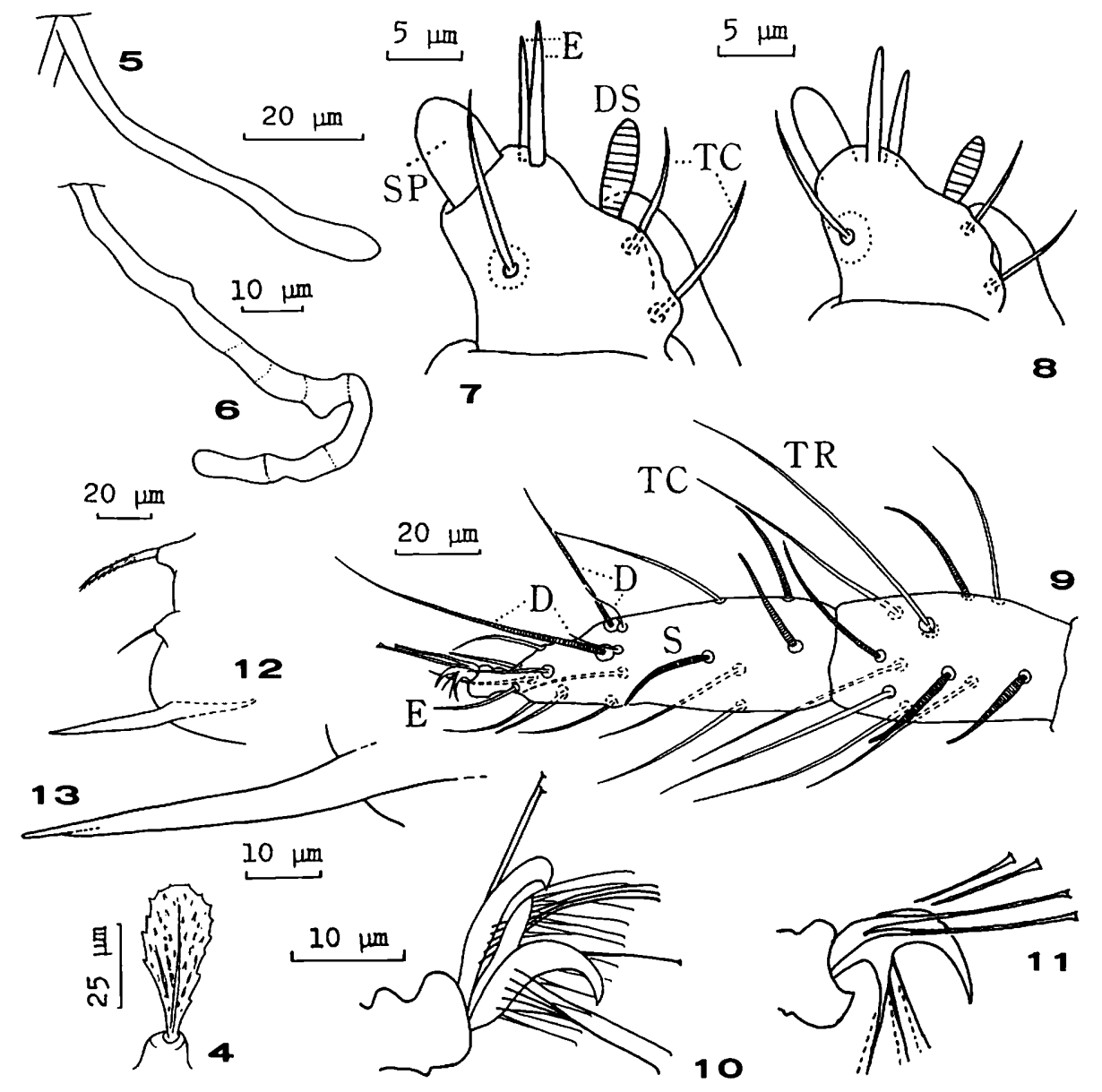

Figs 4-13. Some body parts of taxonomic importance. 4, dorsal seta of Bryobia eharai ( o ); 5 , peritreme of Eotetranychus uchidai ( + ); 6, ditto, Tetranychus ludeni ( + ); 7, distal segment of palpus of T. ludeni ( 8 ); 8, ditto $\left(\sigma^{7}\right) ; 9$, tarsus and tibia I of Panonychus mori $\left(\sigma^{7}\right)$; 10, claws and empodium of leg I of Pseudobryobia japonica ( + ); 11 , tenent hairs and empodial claw of leg I of Panonychus ( 9, schematic); 12, caudal end of Tetranychina harti ( $\sigma^{7}$, lateral view), with aedeagus; 13, aedeagus of T. harti. D, duplex setae; DS, dorsal sensillum; E, eupathidium; S, solenidion; SP, spinneret; TC, tactile setae; TR, trichobothrium.

terminal sensillum, but after Alberti and Storch's work (1974) it has usually been termed the spinneret. The shape of the spinneret is often important for species recognition. However, it may show considerable intraspecifical variability in the male (e.g., some species of Eotetranychus). Moreover, the males of some species are consistently deficient in the spinneret (e.g., some species of Eotetranychus and Schizotetranychus). In the Bryobiinae the spinneret remains a simple terminal eupathidium which does not spin. On the distal segment of the tetranychid palpus a 


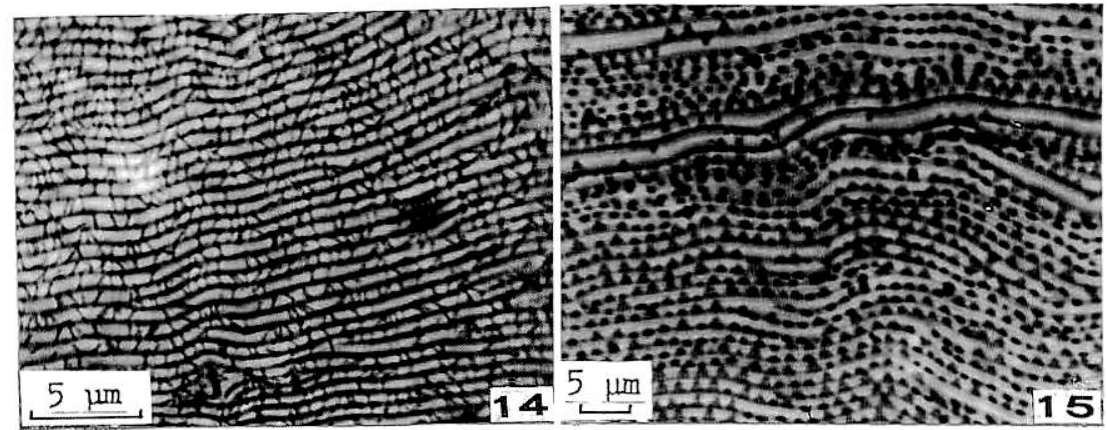

Fig. 14. Photomicrograph of dorsal opisthosomal striae of Amphitetranychus viennensis (우). Fig. 15. Ditto, Tetranychus ludeni (우).

conspicuous solenidion occurs proximal to the spinneret. This solenidion, often called the dorsal sensillum, is usually fusiform or subcylindrical, but it is not very useful for identification.

Tarsi I-IV and tibia I of both sexes and tibia II of the male are provided with solenidia in addition to the other setae (Fig. 9). A solenidion is rarely found on tibiae III and IV (e.g., a Thai species, Oligonychus yasumatsui Ehara and Wongsiri, 1975). The solenidia, formerly often called the sensory setae, are nude, transversely striate, and mostly blunt-ended. Most of the other setae on the legs are ordinary setae (usually called the tactile setae), which are pubescent and taper to a sharp tip. The rest of the leg setae consist of a few eupathidia and trichobothria. The former occur at and near the ends of tarsi I and II, and are nude, blunt-ended, and lacking in transverse striae, while the latter are found singly on the dorsum of tibia I, but can barely be discriminated from the tactile setae. The dorsum of tarsus I of most tetranychids carries two pairs of closely (or loosely) associated setae that are termed the duplex setae (Fig. 9). A single pair of duplex setae is located on the dorsum of tarsus II. Each pair of duplex setae consists of a long distal solenidion and a short, proximal, tactile seta. The duplex setae may occur on tarsi III and IV. The chaetotaxy on the legs is very important for recognition of species and species group. In addition, the tactile setae on tarsi III and IV may vary in number among specimens of the same population.

The distal end of the tarsus is furnished with a pair of true claws and a central empodium. The true claws remain claw-like in the Bryobiini (Fig. 10), but are mostly reduced to a pair of knobbed hairs that are termed the tenent hairs (Fig. 11). The empodium generally varies among subfamilies, tribes, and genera; for example, it is represented by a pad having two rows of knobbed hairs in Bryobia and Pseudobryobia (Fig. 10), but is claw-like (empodial claw) with proximoventral hairs in Panonychus, Sasanychus, and Oligonychus (Fig. 11). In addition, the empodia of legs I and II of the male may differ from those of legs I-IV of the female and legs III and IV of the male (e.g., Eotetranychus and Tetranychus).

The shape of the male genital organ, the aedeagus (Figs 12,13) is very important in determining the species of most tetranychids. The male must be oriented accurately in lateral view in order to observe the outline of the aedeagus, which is usually characteristic for each species. 
Family Tetranychidae Donnadieu, 1875

Tétranycidés Donnadieu, 1875: 9.

Tetranychidae: Murray 1877: 97; Pritchard and Baker 1955: 4.

Type genus: Tetranychus Dufour, 1832.

Key to the Subfamilies of Tetranychidae

1. Empodium with tenent hairs; female with 3 pairs of anal setae and male with 5 pairs of genito-anal setae …............................................ Bryobinae

Empodium (rarely absent) without tenent hairs; female with 1 or 2 pairs of anal setae and male with 3 or 4 pairs of genito-anal setae ….......... Tetranychinae

Subfamily Bryobiinae Berlese, 1913

Bryobiini Berlese, 1913: 17.

Bryobiinae: Reck 1950: 122; Pritchard and Baker 1955: 12.

Bryobiidae: Reck 1952: 422.

Type genus: Bryobia Koch, 1836.

Key to the Tribes of Bryobiinae in Japan

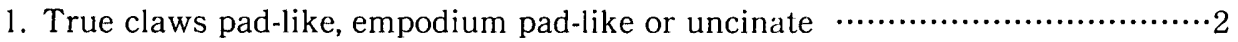

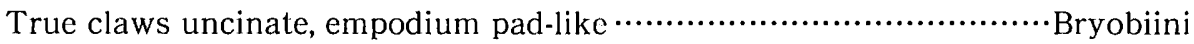

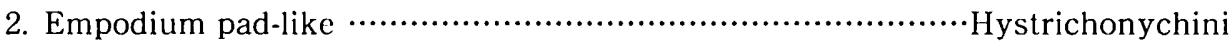

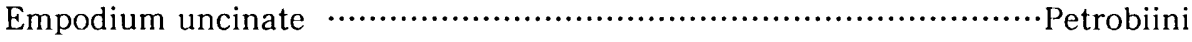

Tribe Bryobiini Berlese, 1913

Bryobiini Berlese, 1913: 17; Pritchard and Baker 1955: 14.

Type genus: Bryobia Koch, 1836.

This tribe is distinctive in having the true claws uncinate and the empodium pad-like. Two genera are known from Japan, Bryobia and Pseudobryobia.

Key to the Genera of Bryobiini in Japan

1. Prodorsum with prominent setiferous lobes over the gnathosoma $\cdots \cdots \cdots \cdot$ Bryobia Prodorsum without prominent setiferous lobes over the gnathosoma 
Genus Bryobia Koch, 1836

Bryobia Koch, 1836: 8; Pritchard and Baker 1955: 14.

Type species: Bryobia praetiosa Koch, 1836, by subsequent designation of Baker and Wharton (1952).

Prodorsum with 4 pairs of setae (P0, P1, P2, P3), setae P0 and P1 on prominent lobes. Opisthosoma with 12 pairs of dorsal setae. True claws uncinate, with tenent hairs; empodium pad-like, with tenent hairs.

Some species of this genus are thelytokous since no males have been found, while the others are bisexual and arrhenotokous.

Key to the Species of Bryobia in Japan (Females)

1. Idiosoma with caudal end gently curved; empodium of leg I with 1 or 2 pairs of tenent hairs

Idiosoma with caudal end slightly concave; empodium of leg I with 2 rows of tenent hairs ......................................................................pritchardi

2. Palpal claw not cleft at tip; empodium of leg I with 1 pair of tenent hairs $\cdots \cdots \cdot 3$ Palpal claw cleft at tip; empodium of leg I with 2 pairs of tenent hairs $\cdots$ eharai

3. Seta $\mathrm{Pl}$ on outer lobes of prodorsum usually reaching middle of $\mathrm{P0}$ on inner lobes; leg I $660 \mu \mathrm{m}$ long .......................................................rubrioculus

Seta $\mathrm{Pl}$ on outer lobes of prodorsum, in general, not or hardly reaching base of P0 on inner lobes; leg I $840 \mu \mathrm{m}$ long -praetiosa

\section{Bryobia pritchardi Rimando, 1962}

(Figs 16-18)

Bryobia pritchardi Rimando, 1962: 9, figs 3, 4; Ehara 1969c: 83, figs 1-3; Ehara 1971: 10, figs 15-17; Wang 1981: 33, fig. 19; Ma et al. 1984: 103, fig. 8 (16) (copies of figures from Ehara 1969c, 1971); Tseng 1990: 15, figs 28-32. [Type locality: Lipa City, Batangas, Philippines; type host: Paederia foetida $]$

Both sexes are known to occur. Females of this species are distinctive among those of the Japanese species of Bryobia in having the posterior end of the body slightly concave.

Hosts. In Japan: Paederia scandens, fruit of prince melon (Cucumis melo var.).

Distribution. Shikoku, Kyushu; China, Hainan Island, Taiwan, Philippines.

2. Bryobia eharai Pritchard and Keifer, 1958

(Figs 4, 19, 20)

Bryobia eharai Pritchard and Keifer, 1958: 506; Ehara 1959b: 186, figs 1-6, 39, 40, 43; Jeppson et al. 1975: 127, fig. 5; Wang 1981: 31, fig. 18; Tseng 1990: 10, figs 16-20. [Type loc.: Japan (at Seattle, Washington quarantine); type host: Chrysanthemum 


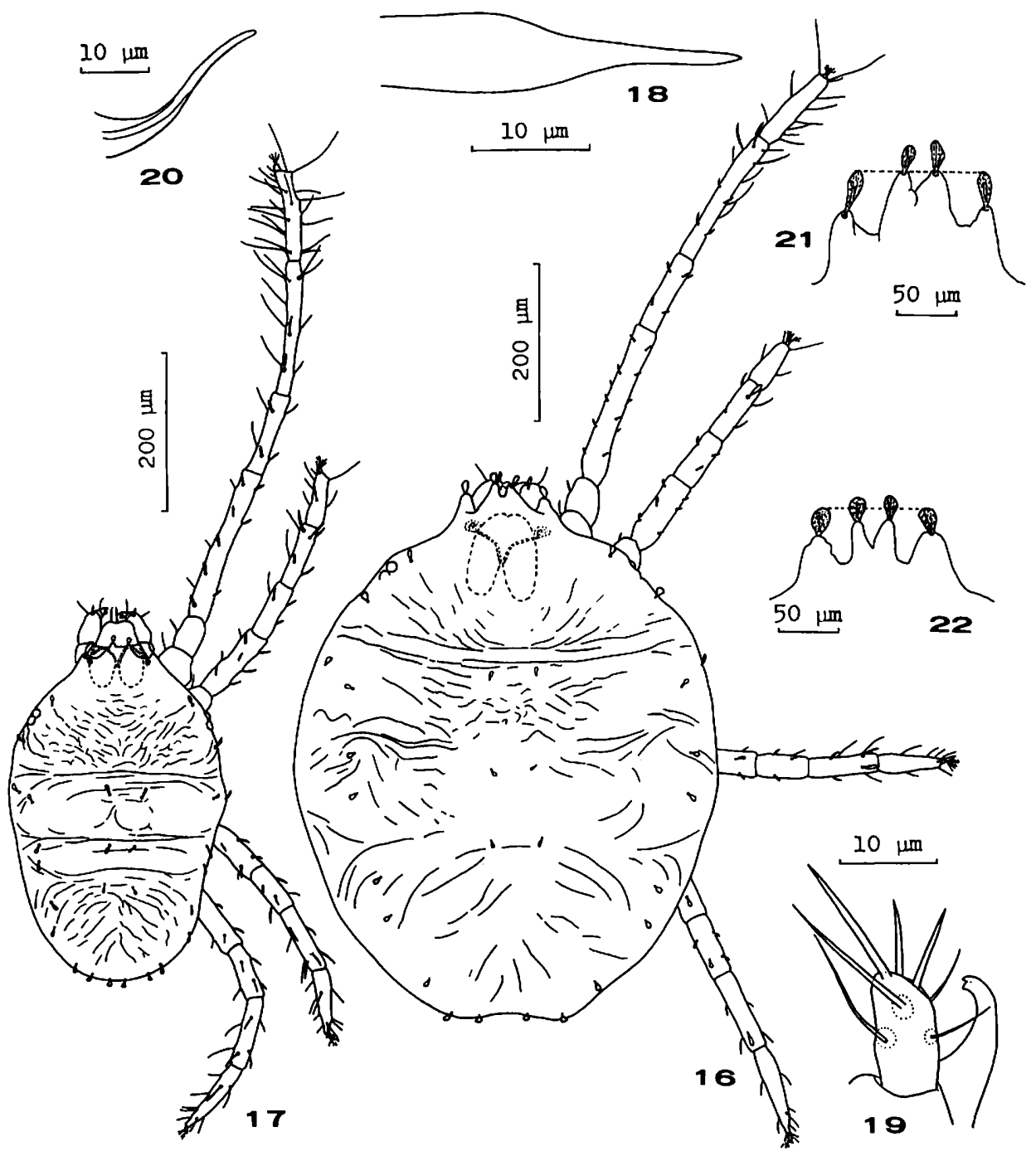

Figs 16-18. Bryobia pritchardi. 16, dorsum ( $(+) ; 17$, dorsum $\left(\sigma^{7}\right)$; 18, aedeagus. Figs 19, 20. Bryobia eharai. 19, distal segment of palpus (ㅇ ); 20, aedeagus. Figs 21, 22. Anterior projections of prodorsum of Bryobia ( + ) . 21, B. praetiosa; 22, B. rubrioculus.

sp.]

Bryobia (Eharobia) eharai: Livshitz and Mitrofanov 1971: 99, figs 5a, $13 a, 60$. Bryobia cristata (nec Dugès): Pritchard and Baker 1955: 22, figs 16-18.

Both sexes are known to occur. In addition to the characters mentioned in the key, the large and spatulate setae on the idiosomal dorsum are characteristic of $B$. eharai. 
Hosts. In Japan: Chrysanthemum, Artemisia princeps.

Distribution. Honshu, Shikoku, Kyushu; China, Taiwan, India, Pakistan, Russia.

\section{Bryobia praetiosa Koch, 1836}

(Fig. 21)

Bryobia praetiosa Koch, 1836: 8. [Type loc:: Germany; type host: shrubbery]

Bryobia praetiosa: Pritchard and Baker 1955: 26, figs 19, 20; Ehara 1956a: 244, figs 1, 2; Ehara 1959b: 190, figs 12-34, 37, 38, 42; Wainstein 1960: 102, figs 33, 76, 77 , 115; Meyer 1974: 20, figs 57-65; Jeppson et al. 1975: 129, fig. 6; Wang 1981: 28, figs 15, 16a, 16b; Vacante 1985: 53, pls. 2, 3, figs 10-19; Ehara and Shinkaji 1993: 52, fig. 26; Baker and Tuttle 1994: 23, fig. 8.

Bryobia (Bryobia) praetiosa: Livshitz and Mitrofanov 1971: 59, fig. 33.

Leg I of Bryobia praetiosa (female) is approximately as long as or longer than the idiosoma. This species has been regarded as a complex of very allied races, rather than a monotypic species. At least four biotypes of the species have been recognized to occur in Europe by many workers; one of these is now called B. rubrioculus (Scheuten, 1857). In Japan there are at least three types (forms) that differ from each other in external characters (Ehara 1959b). This mite is well known as a pest of agricultural crops, but is also an occasional pest of medical importance because of its propensity for invading homes. No males have been found in the world.

Hosts. In Japan: grass, clover, Lathyrus japonicus, strawberry, cucumber, watermelon, cabbage, iris, apple (rare), mitsuba (Cryptotaenia japonica), China aster, Maianthemum dilatatum, etc.; fruit of prince melon (Cucumis melo var.).

Distribution. Cosmopolitan.

\section{Bryobia rubrioculus (Scheuten, 1857)}

(Fig. 22)

Sannio rubrioculus Scheuten, 1857: 111, pl. 7, figs 12-14. [Type loc.: Germany; type host: fruit tree]

Bryobia from apple and pear: Eyndhoven 1955: 344, figs 4-6.

Bryobia rubrioculus: Eyndhoven 1956: 45; Ehara 1959b: 188, figs 7-11, 35, 36, 41; Baker and Pritchard 1960: 457; Meyer 1974: 23, figs 77-85; Jeppson et al. 1975: 133, fig. 8, pl. 23; Wang 1981: 30, figs 14a, 16c, 16d, 17; Vacante 1985: 60, pl. 10, figs 56-64; Tseng 1990: 15, figs 33-38; Ehara and Shinkaji 1993: 52, fig. 27; Baker and Tuttle 1994: 24, fig. 9.

Bryobia arborea Morgan and Anderson, 1957: 486, fig. 1; Morgan 1960: 1A-1D, 2A (1.), $2 \mathrm{~B}(1),. 2 \mathrm{C}(\mathrm{I}),. 2 \mathrm{D}$.

Bryobia rubrioculus closely resembles $B$. praetiosa, but differs from it in having the body smaller and seta $\mathrm{P} 1$ reaching the middle of P0. Moreover, tarsus IV of $B$. rubrioculus is dorsally provided with a distal solenidion well separated from the tactile setae, whereas in B. praetiosa one set of duplex setae is located on the distal dorsum of tarsus IV. No males. 
Hosts. In Japan: apple, Malus micromalus, pear, sour cherry.

Distribution. Hokkaido, Honshu; Korea, China, Taiwan, India, Pakistan, Iran, Iraq, Yemen, U.K., Europe, North and South America, Africa, Australia, New Zealand, etc.

\section{Genus Pseudobryobia McGregor, 1950}

Pseudobryobia McGregor, 1950: 366.

Type species: Pseudobryobia bakeri McGregor, 1950, by original designation.

Prodorsum with 4 pairs of setae, without anterior lobes. Opisthosoma with 12 pairs of dorsal setae. True claws uncinate, with tenent hairs; empodium pad-like, with tenent hairs.

The genus Pseudobryobia is similar to a Russian genus, Strunkobia Livshitz and Mitrofanov, 1972, but differs from the latter in having one pair of pregenital setae and one pair of hypostomal setae instead of two pairs of each.

\section{Pseudobryobia japonica (Ehara and Yamada, 1968)}

(Figs 3, 10)

Bryobia japonica Ehara and Yamada, 1968: 66, figs 1-10. [Type loc.: Kuroishi, Aomori

Pref.; type host: wild rose]

Bryobia (Allobia) japonica: Livshitz and Mitrofanov 1971: 87.

Pseudobryobia japonica: Ehara 1996: 47, figs 2-1-4a, 2-1-7b, 2-1-11a, 2-2-7.

The male is not known.

Host. Wild rose (Rosa multiflora).

Distribution. Honshu; Korea.

Tribe Hystrichonychini Pritchard and Baker, 1955

Hystrichonychini Pritchard and Baker, 1955: 35.

Type genus: Hystrichonychus McGregor, 1950.

This tribe is characterized by having the true claws and empodium pad-like. Only one genus, Tetranycopsis, is known from Japan.

\section{Genus Tetranycopsis Canestrini, 1889}

Tetranycopsis Canestrini, 1889: 495.

Type species: Tetranychus horridus Canestrini and Fanzago, 1876, by monotypy.

Prodorsum with 4 pairs of setae, opisthosomal dorsum with 12 pairs of setae; all dorsal idiosomal setae set on strong tubercles, and most of them contiguous. True 
claws and empodia pad-like, each with tenent hairs.

6. Tetranycopsis borealis Ehara and Mori, 1969

(Figs 23-25)

Tetranycopsis borealis Ehara and Mori, 1969: 45, figs 1-7; Ehara 1971: 11. [Type loc.: Toyotomi (Sarobetsu peatland), Sōya Prov., Hokkaido; type host: Rubus chamaemorus]

No males of this species have as yet been found.

Hosts. Rubus chamaemorus, $R$. parvifolius.

Distribution. Hokkaido, Honshu; Russia.

Tribe Petrobiini Reck, 1952

Petrobiinae Reck, 1952: 423.

Petrobiini: Pritchard and Baker 1955: 42.

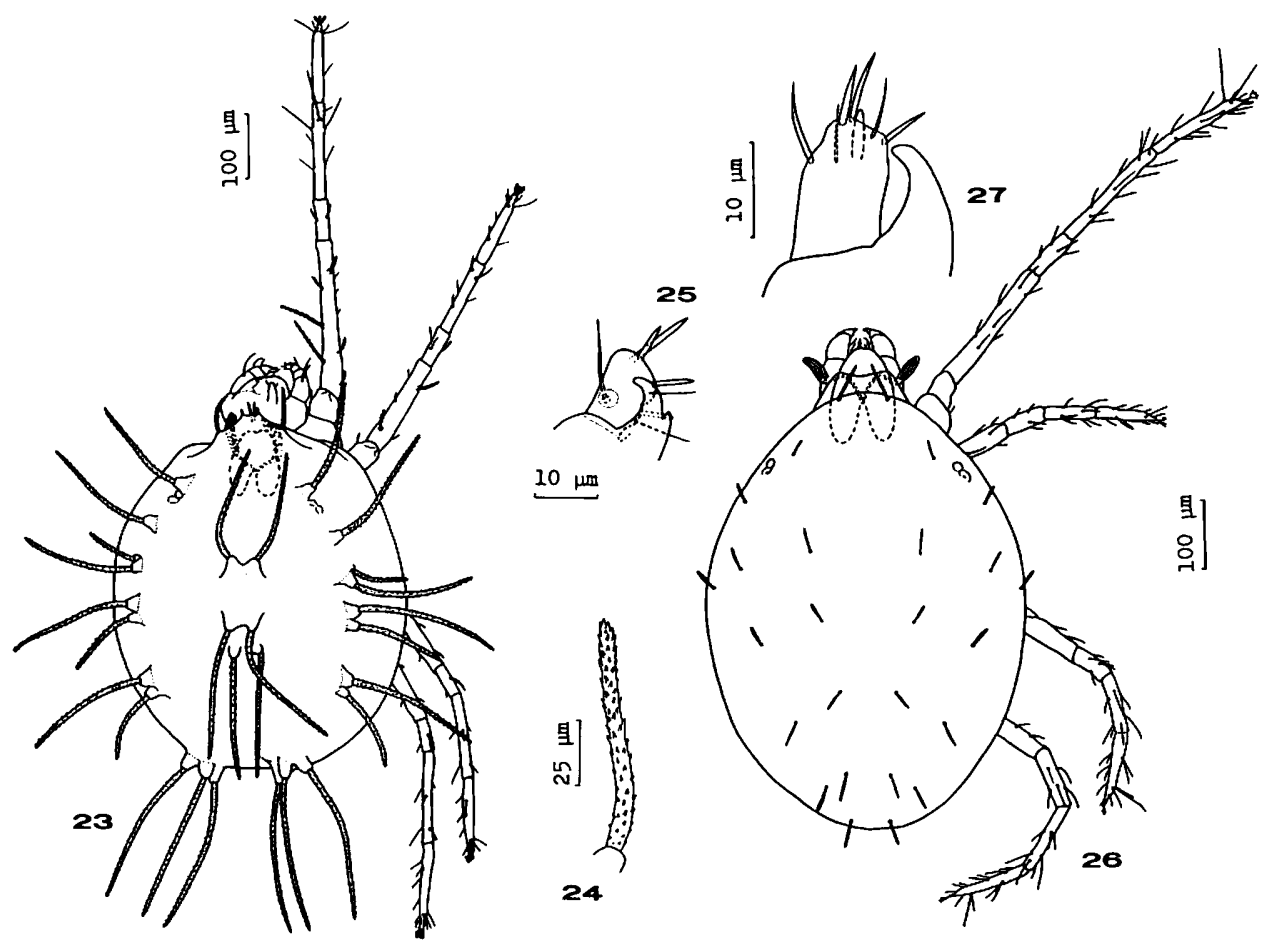

Figs 23-25. Tetranycopsis borealis ( $\$$ ). 23 , dorsum; 24 , humeral seta; 25 , distal segment of palpus. Figs 26, 27. Petrobia latens ( + ). 26, dorsum; 27, distal segment of palpus. 
Type genus: Petrobia Murray, 1877.

This tribe is distinctive in having the true claws pad-like and the empodium uncinate. Two genera are known from Japan, Petrobia and Tetranychina.

Key to the Genera of Petrobiini in Japan

1. Dorsal idiosomal setae not on tubercles Petrobia

Some or all of the dorsal idiosomal setae on tubercles Tetranychina

Genus Petrobia Murray, 1877

Petrobia Murray, 1877: 118.

Type species: Trombidium lapidum Hammer in Hermann $1804=$ Petrobia latens (Müller, 1776), by original designation.

Prodorsum with 3 pairs of setae, opisthosomal dorsum with 10 pairs of setae; all dorsal idiosomal setae not set on tubercles. True claws pad-like, with tenent hairs; empodium uncinate, with tenent hairs.

\section{Petrobia latens (Müller, 1776)}

(Figs 26, 27)

Acarus latens Müller, 1776: 287. [Type loc.: Denmark, under stones]

Trombidium lapidum Hammer in Hermann 1804: 49.

Petrobia lapidum: Murray 1877: 118.

Petrobia latens: Oudemans 1915: 44; Baker and Pritchard 1953: 206, figs 2, 3; Pritchard and Baker 1955: 51, figs 37, 38; Ehara 1956a: 246, figs 3, 4; Ehara 1959b: 195; Wang 1981: 36, fig. 22; Baker and Tuttle 1994: 121, fig. 77.

Petrobia (Petrobia) latens: Wainstein 1960: 134, fig. 155; Jeppson et al. 1975: 142, fig. 12.

Petrobia latens is characterized by having the dorsal idiosomal setae shorter than the distances between them, and the distal portion of the peritreme horn-like, anastomosing, and protruding. No males have been found in the world.

Hosts. In Japan: grass, barley, Trifolium repens, soybean, adzuki bean, kidney bean, strawberry, stone leek.

Distribution. Hokkaido, Honshu; nearly worldwide.

Genus Tetranychina Banks, 1917

Tetranychina Banks, 1917: 195.

Type species: Tetranychina apicalis Banks, 1917, by original designation.

Prodorsum with 3 pairs of setae, opisthosoma with 10 pairs of dorsal setae; Some 
or all of the dorsal idiosomal setae set on prominent tubercles. True claws pad-like, with tenent hairs; empodium uncinate, with tenent hairs.

\section{Tetranychina harti (Ewing, 1909)}

(Figs 12, 13)

Neophyllobius harti Ewing, 1909: 405, pl. 14, fig. 7. [Type loc.: Carbondale, Illinois; type host: moss]

Tetranychina harti: Banks 1917: 195; McGregor 1950: 363; Meyer 1974: 132; Meyer 1987: 74, figs 351-353; Ehara 1989b: 360; Ehara and Shinkaji 1993: 54, fig. 28; Baker and Tuttle 1994: 127, fig. 81; Ryu and Ehara 1995: 19, figs 14-24.

Petrobia harti: Pritchard and Baker 1955: 45, figs 28-30; Ehara 1959b: 192, figs 44-52; Wang 1981: 34, fig. 20.

Petrobia (Tetranychina) harti: Wainstein 1960: 137; Tuttle and Baker 1968: 72.

Tetranychina tuberculata Kishida, 1921: 440, figs 1-4.

Tetranychina harti is distictive in having the dorsal idiosomal setae arising from strong tubercles. In the female, leg I is about twice as long as the idiosoma, while in male it is about three times as long as the idiosoma. Recently the internal morphology of this mite was investigated by Matsubara et al. (1992).

Kishida (1921) recorded this species from human urine under the name $T$. tuberculata. The single female on which $T$. tuberculata was based was, when found, dark red and moving about in the urine within the test tube. Therefore, it is almost certain that the mite had invaded the tube beforehand (Ehara 1977b).

Hosts. Primarily parasitic on Oxalis, occasionally found on its neighboring low-growing plants.

Distribution. Honshu, Shikoku, Kyushu, Okinawa Island; nearly worldwide.

\section{Subfamily Tetranychinae Berlese, 1913}

Tetranychini Berlese, 1913: 17.

Tetranychinae: Reck 1950: 123; Pritchard and Baker 1955: 96.

Tetranychidae: Reck 1952: 423.

Type genus: Tetranychus Dufour, 1832.

Key to the Tribes of Tetranychinae in Japan

1. Empodium rudimentary or absent; tarsus I dorsally with loosely associated duplex setae or without duplex setae …..........................Eury tetranychini

Empodium conspicuous; tarsus I dorsally with 2 sets of closely associated duplex setae -Tetranychini 
Eurytetranychinae Reck, 1950: 123.

Eurytetranychini: Pritchard and Baker 1955: 100.

Type genus: Eurytetranychus Oudemans, 1931.

This tribe may be distinguished by the rudimentary, claw-like, or absent empodium and by the duplex setae on legs I and Il, if present, being usually loosely associated. The females have one or two pairs of anal setae, the males three or four paris of genito-anal setae. The Tasmanian genus Synonychus Miller, 1966 markedly differs from the other genera of the tribe in having the empodial claw stout and about half as long as the tenent hairs of the true claws.

Three genera are known from Japan, Eurytetranychoides, Eutetranychus and Aponychus.

Key to the Genera of Eurytetranychini in Japan (Females)

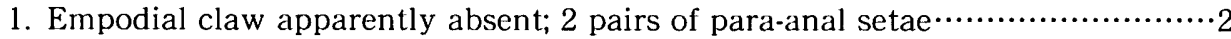

Empodial claw present, tiny; 1 pair of para-anal setae............. Eurytetranychoides

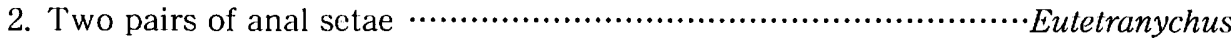

One pair of anal setae

Genus Eurytetranychoides Reck, 1950

Eurytetranychoides Reck, 1950: 127.

Type species: Eurytetranychus thujae Reck, 1947, by original designation.

Empodium claw-like, very small. Duplex setae on legs not closely associated with each other. One pair of para-anal setae. Female with 2 pairs of anal setae; male with 4 pairs of genito-anal setae.

\section{Eurytetranychoides japonicus (Ehara, 1980)}

(Figs 28, 29)

Eurytetranychus japonicus Ehara, 1980: 202, figs 1-11. [Type loc.: Mashiko, Tochigi Pref.; type host: Quercus glauca]

Eurytetranychoides japonicus: Ehara 1989b: 357, fig. 1, A-C.

The female of this species is distinctive in having the dorsal idiosomal setae of very different sizes, and seta $\mathrm{C} 2$ minute.

Host. In Japan: Quercus glauca.

Distribution. Honshu; China. 


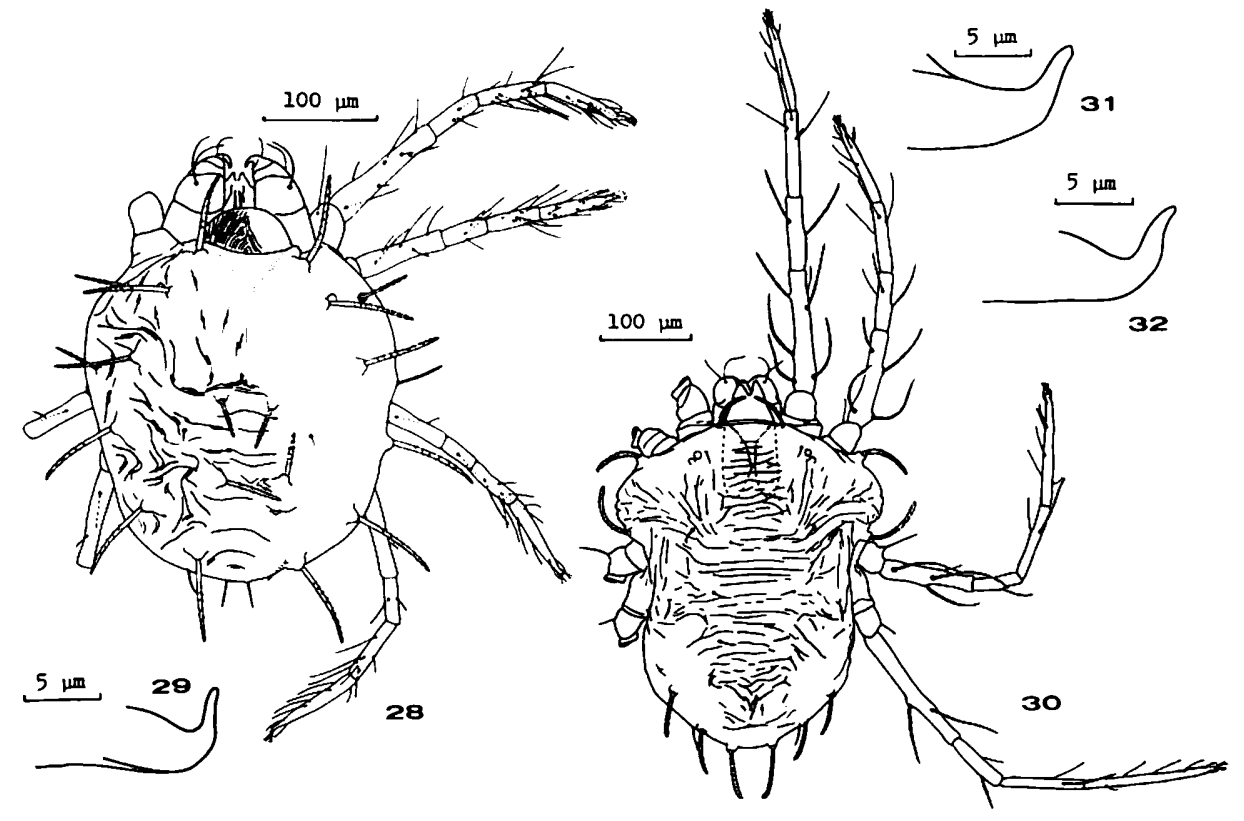

Figs 28, 29. Eurytetranychoides japonicus. 28, dorsum ( + ); 29, aedeagus. Figs 30, 31. Aponychus corpuzae. 30, dorsum (ㅇ); 31, aedeagus. Fig. 32. Aponychus firmianae, aedeagus.

Genus Eutetranychus Banks, 1917

Neotetranychus (Eutetranychus) Banks, 1917: 197.

Eutetranychus Banks: McGregor 1950: 267.

Type species: Tetranychus banksi McGregor, 1914, by original designation.

Empodial claw apparently absent. Duplex setae on legs loosely associated with each other. Two pairs of para-anal setae. Female with 2 pairs of anal setae; male with 4 pairs of genito-anal setae.

\section{Eutetranychus orientalis (Klein, 1936)}

Anychus orientalis Zacher (nomen nudum): Klein 1936: 107, fig. 1 [Type loc.: Israel; type host: citrus]

Eutetranychus banksi (nec McGregor): Pritchard and Baker 1955: 115 (in part); Ehara 1963a: 144, figs 1-10.

Eutetranychus orientalis: Baker and Pritchard 1960: 464, fig. 5; Ehara 1969c: 86, figs 4-11; Ehara and Lee 1971: 75, figs 48-50; Ehara and Wongsiri 1975: 150; Wang 1981: 43, fig. 29; Ma et al. 1984: 114, fig. 8(26); Meyer 1987: 80, figs 377-390; Ehara and Tho 1988: 2; Tseng 1990: 25, figs 48-62; Ehara and Yogi 1998: 530, figs $1-4$. 
Eutetranychus orientalis was very recently recognized to occur in the Ryukyu Islands (Ehara and Yogi 1998). According to Bolland et al. (1998), this species was formerly recorded from Japan by Klein (1936), but such a record is not found in Klein's paper. E. orientalis resembles $E$. banksi (McGregor) of the Western hemisphere, but can be distinguished by having setae $\mathrm{C} 4$ nearly caudal to C3.

Hosts. In Japan: papaya, Citrus depressa, Murraya paniculata, frangipani (Plumeria rubra f. acutifolia), Thevetia peruviana, croton, Jatropha integerrima, Fucus microcarpa f., F. septica f., Erythrina variegata, E. speciosa, E. crista-galli, Bauhinia, Acacia confusa, Gardenia jasminoides, Cassia fistula, C. surattensis, Pachira aquatica, Cosmos sulphureus, Rosa.

Distribution. Okinawa Island, Tsuken I., Miyako I; China, Taiwan, Philippines, Thailand, Malaysia, India, Pakistan, Afghanistan, Iran, Israel, Jordan, Turkey, Cyprus, Africa, ctc.

Genus Aponychus Rimando, 1966

Aponychus Rimando, 1966: 107.

Chinotetranychus Ma and Yuan, 1982: 109.

Type species: Aponychus corpuzae Rimando, 1966, by original designation.

Empodial claw apparently absent. Duplex setae on legs not closely associated with each other. Two pairs of para-anal setae. Female with 1 pair of anal setae; male with 3 pairs of genito-anal setae.

Key to the Species of Aponychus in Japan (Females)

1. Idiosoma with lateral surfaces concave above coxae III and IV ………corpuzae Idiosoma with lateral surfaces not concave ….................................. firmianae

\section{Aponychus corpuzae Rimando, 1966}

(Figs 30, 31)

Aponychus corpuzae Rimando, 1966: 107, figs 1-4; Rimando 1968: 7, fig. 1; Ehara 1969c: 87, figs 12-18; Wang 1981: 46, fig. 32; Ma et al. 1984: 112, fig. 8 (25) (A, C: copies of figures from Ehara 1969c); Ehara and Saito 1993: 56, fig. 29. [Type loc.: Mt. Maquiling, Laguna, Philippines; type host: Schizostachyum lima]

The female can easily be recognized by the laterally concave idiosoma and by the two size classes of dorsal idiosomal setae.

Hosts. In Japan: bamboo and bamboo grass.

Distribution. Hokkaido, Honshu, Shikoku, Kyushu; Korea, China, Hainan Island, Taiwan, Philippines, Thailand, Malaysia, India. 
12. Aponychus firmianae (Ma and Yuan, 1965)

(Fig. 32)

Eutetranychus firmianae Ma and Yuan, 1965: 247, figs 1-13. [Type loc.: Hsing Yu, Kiangsi Prov., China; type host: Firmiana simplex]

Aponychus firmianae: Ehara 1980: 206, figs 12-22; Ehara and Gotoh 1993b: 58, fig. 30. Chinotetranychus firmianae: Ma and Yuan 1982: 109.

The female is characterized by the dorsal idiosomal setae arising from strong tubercles and being similar to each other in length except for L4, which is much shorter. It is also distinct in having coxa II with one tactile seta.

Host. In Japan: Firmiana simplex.

Distribution. Ilonshu; Korea, China.

Tribe Tetranychini Reck, 1950

Tetranychinae Reck, 1950: 123.

Tetranychini: Pritchard and Baker 1955: 124.

Type genus: Tetranychus Dufour, 1832.

This tribe is characterized by the claw-like or distally split empodium and the presence of two pairs of duplex setae on tarsus I and one pair on tarsus II. Members of the tribe are provided with seta $\mathrm{C} 4$ in the normal position, in contrast to this seta's marginal position or absence in the tribe Tenuipalpoidini Pritchard and Baker, 1955. In the Japanese members, the female bears two pairs of anal setae while the male has four pairs of genito-anal setae.

Eight genera are known from Japan: Panonychus, Sasanychus, Schizotetranychus, Yezonychus, Eotetranychus, Oligonychus, Amphitetranychus, and Tetranychus.

Key to the Genera of Tetranychini in Japan (Females)

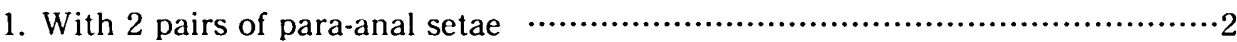

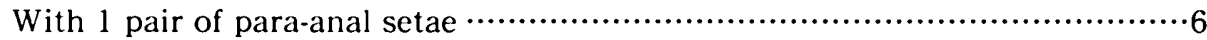

2. Empodium claw-like …......................................................................

Empodium not claw-like, comprised of 3 pairs of hairs $\cdots . . . . . . . . . .$. Eotetranychus

3. Empodium a single claw-like structure, with proximoventral hairs $\cdots \cdots \cdots \cdots \cdots \cdot \ldots$

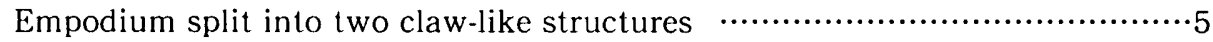

4. Body globular, dorsal idiosomal setae set on prominent tubercles ...Panonychus Body slender, dorsal idiosomal setae not on tubercles .................... Sasanychus

5. Opisthosoma with 9 pairs of dorsal setae (L4 setae absent) ……..... Yezonychus Opisthosoma with 10 pairs of dorsal setae …..................... Schizotetranychus

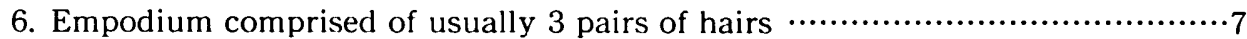

Empodium claw-like, with proximoventral hairs ........................ Oligonychus

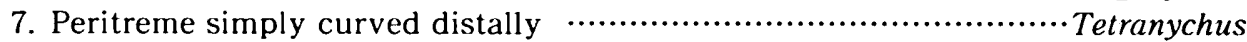

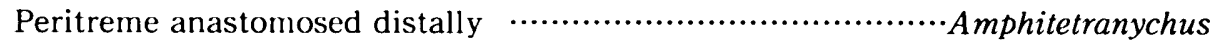


Panonychus Yokoyama, 1929: 531; Ehara 1956c: 499; Meyer and Ryke 1959: 350;

Baker and Pritchard 1960: 471; Ehara and Gotoh 1992: 108.

Metatetranychus Oudemans, 1931a: 199; Pritchard and Baker 1955: 127.

Type species: Panonychus mori Yokoyama, 1929, by monotypy.

Female: Body rotund. Dorsal idiosomal setae set on prominent tubercles. Opisthosoma with longitudinal striae between pair of $\mathrm{C} 1$ setae and between pair of $\mathrm{C} 2$ setae. Two pairs of para-anal setae present. Empodium claw-like, with 3 pairs of proximoventral hairs all similar in length and set at nearly right angle to claw. Two sets of duplex setae on tarsus I adjacent. Tibia I with 7 tactile setae; tibia II with 5 tactile setae.

In Panonychus males are commonly found as in the other genera of the Tetranychini, except for $P$. thelytokus in which the male is very rare. Six species of this genus are known to occur in Japan, and they are now divided into two species groups.

Key to the Species Groups of Panonychus in Japan

1. Genua I and II each with 4 tactile setae; genu III with 2 tactile setae

bambusicola species group

Genua I and II each with 5 tactile setae; genu III with 3 tactile setae mori species group

\section{bambusicola species group}

Exemplar species: Panonychus bambusicola Ehara and Gotoh, 1991.

Genua I and II each bearing 4 tactile setae; genua III and IV each with 2 tactile setac.

13. Panonychus bambusicola Ehara and Gotoh, 1991

(Fig. 34)

Panonychus bambusicola Ehara and Gotoh, 1991: 9, figs 1-7, 10-13. [Type loc.: Hokkaido Univ. campus, Sapporo, Hokkaido; type host: Sasa senanensis]

The females are usually blackish red in color, but become transparently dark red when they deposit their diapausing eggs (Gotoh and Ehara 1992). The dorsal idiosomal setae are located on strong, white tubercles.

Hosts. Bamboo grass (Sasa senanensis, Sasamorpha borealis).

Distribution. Hokkaido, Honshu.

mori species group 
Exemplar species: Panonychus mori Yokoyama, 1929.

Genua I and II each with 5 tactile setae; genua III and IV each with 3 tactile setae.

Key to the Species of the mori Species Group in Japan

1. Female with seta L4 approximately two thirds the length of $\mathrm{C} 4 \cdots \cdots \cdots \cdots \cdots \cdots \cdots \cdots \cdots \cdots \cdots$

Female with seta L4 approximately a third the length of $\mathrm{C} 4 \ldots \ldots \ldots \ldots \cdots \cdots \cdots \cdots \cdots \cdots \cdots \cdots$

2. Female palpus with spinneret noticeably longer than broad; duplex setae of female tarsus II with proximal member more or less longer than distal member;

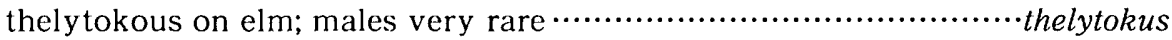

Female palpus with spinneret about as long as broad; duplex setae of female tarsus II with proximal member much shorter than distal member; on

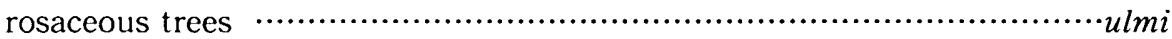

3. Aedeagus with distal sigmoid portion about 1.5 times as long as dorsal margin of shaft; non-diapausing

Aedeagus with distal sigmoid portion about as long as dorsal margin of shaft;

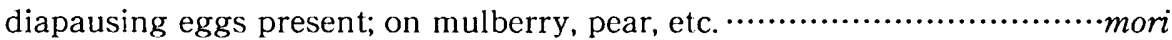

4. Female with seta L3 noticeably shorter than C3; on Osmanthus ….....osmanthi Female with seta L3 approximately as long as C3; mainly on citrus …........citri

14. Panonychus thelytokus Ehara and Gotoh, 1992

(Fig. 35)

Panonychus thelytokus Ehara and Gotoh, 1992: 112, figs 17-23; Ehara and Gotoh 1993a: 157, figs 1-5. [Type loc.: Hokkaido Univ. campus, Sapporo, Hokkaido; ty pe host: Ulmus japonica]

The females are dark red, somewhat greenish, with prominent whitish tubercles that bear the dorsal idiosomal setae. Whenever they deposit their diapausing eggs, they are deep red in color (Gotoh and Ehara 1992). Females of this species differ from those of Panonychus ulmi in the shape of the spinneret and the relative lengths of the duplex setae on tarsus II (cf. key).

Panonychus thelytokus reproduces by thelytoky and its males are very rarely produced (Gotoh and Noguchi 1990; Ehara and Gotoh 1993a). The males are possibly sterile (Ehara and Gotoh 1992).

Host. Japanese elm (Ulmus japonica).

Distribution. Hokkaido.

15. Panonychus ulmi (Koch, 1836)

(Fig. 36)

Tetranychus ulmi Koch, 1836: 11. [Type loc.: Regensburg, Germany; type host: elm] Metatetranychus ulmi: Oudemans 1931a: 198; Pritchard and Baker 1955: 128, figs 93-95; Ehara 1956a: 255, figs 20-22.

Panonychus ulmi: Ehara 1956c: 500; Wainstein 1960: 202; Ehara and Gotoh 1991: 11; 
Ehara and Gotoh 1993b: 64, fig. 33.

Females of the European red mite Panonychus ulmi are dark red in color, but they are transparently red when depositing their diapausing eggs. The presence of strong whitish tubercles that bear the dorsal idiosomal setae is useful for field recognition of this species among spider mites on deciduous fruit trees.

Hosts. In Japan: apple, pear, peach, sweet cherry, plum, apricot, etc.

Distrubution. Hokkaido, Honshu; Korea, China, Taiwan, India, Iran, Armenia, Israel, Turkey, U.K., Europe, Africa, North America, Central America, South America, Australia, Tasmania, New Zealand, etc.

16. Panonychus mori Yokoyama, 1929

(Figs 9, 33, 37)

Panonychus mori Kishida (nomen nudum): Yokoyama, 1929: 531, figs 243, 244; Yokoyama and Ishii 1934: 425, pl. 32; Zacher 1949: 164. [Type loc.: Suginami, Tokyo; type host: mulberry]

Panonychus mori: Ehara and Gotoh 1992: 109, figs 1-12; Ehara and Gotoh 1993b: 62, fig. 32 .

Oligonychus mori: Pritchard and Baker 1955: 341.

Panonychus citri (nec McGregor): Ehara 1956c: 500 (in part); Jeppson et al. 1975: 157 (in part), figs 19B-20.

The females are deep red, somewhat blackish in color, and provided with strong, whitish-red tubercles that bear the dorsal setae. When depositing their diapausing eggs, they become bright red with blackish spots (Gotoh and Ehara 1992).

This species is very closely related to Panonychus citri (see below). However, the aedeagus of $P$. mori is distinctive in having the distal portion strongly sigmoid and about as long as the dorsal margin of the shaft, while in P. cilri the distal portion of the aedeagus is longer and slender, gently sigmoid, and 1.5 times the length of the dorsal margin of the shaft. A redescription of $P$. mori was given by Ehara and Gotoh (1992). It is known to live mainly on deciduous fruit trees and mulberry throughout most parts of Japan, and overwinters as diapausing eggs, whereas $P$. citri attacks mainly citrus leaves in the lower latitude zones, and is non-diapausing. Prior to Ehara and Gotoh (1992) this mite was long referred to as the diapausing strain of P. citri by Japanese workers.

Hosts. Mulberry, pear, peach, Cocculus trilobus.

Distribution. Hokkaido, Honshu, Shikoku, Kyushu.

\section{Panonychus citri (McGregor, 1916)}

(Fig. 38)

Tetranychus citri McGregor, 1916: 286, pl. 14, figs 1-9. [Type loc.: Orlando, Florida; type host: lemon]

Paratetranychus citri: McGregor 1919: 672, pl. 79, fig. 15; McGregor 1950: 335, fig. 15, pl. 38, fig. 2. 


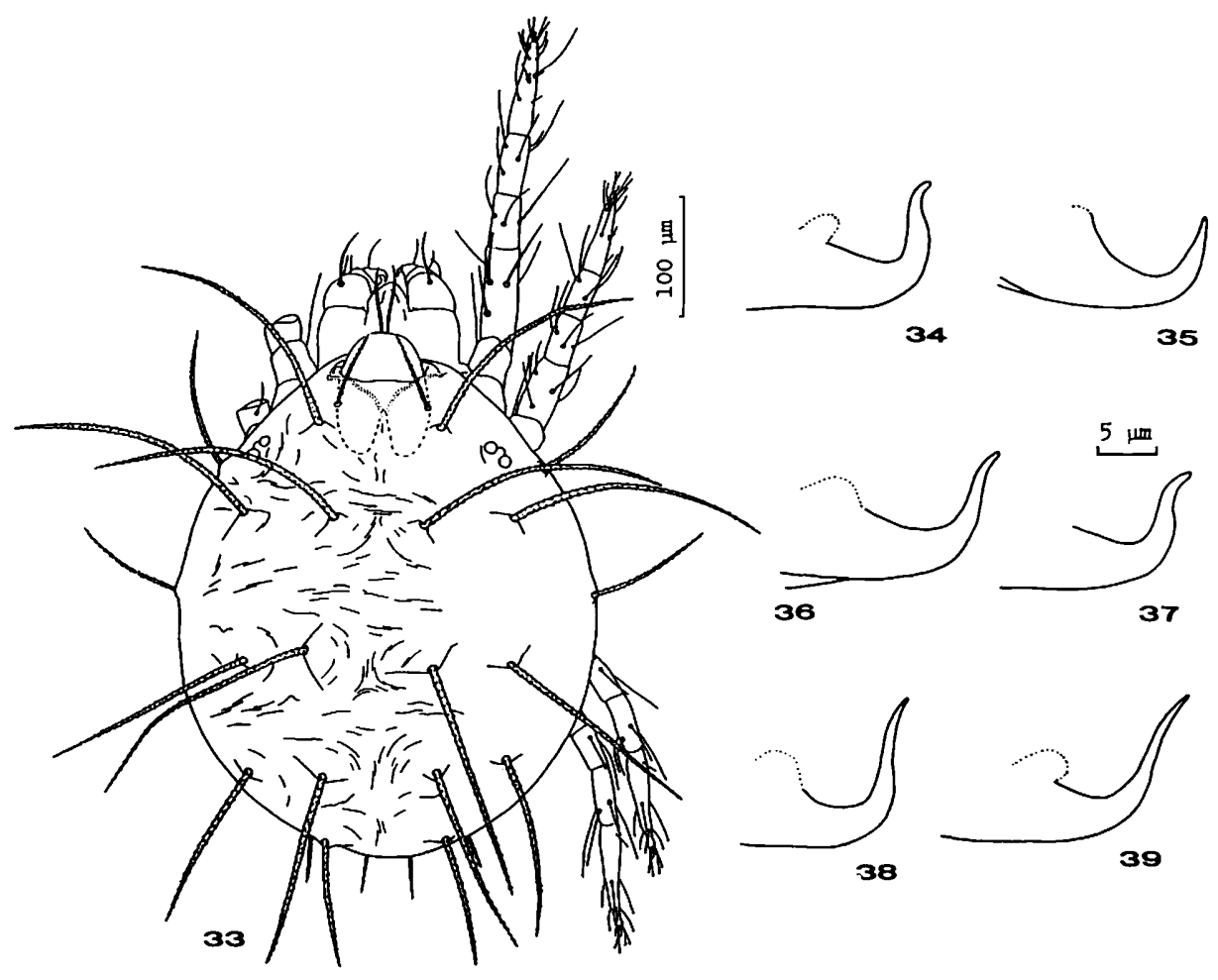

Figs 33. Panonychus mori ( 9 ), dorsum. Figs 34-39. Aedeagi (all at same magnification). 34, Panonychus bambusicola; 35, P. thelytokus; 36, P. ulmi; 37, P. mori; 38, P. citri; 39 , P. osmanthi.

Metatetranychus citri: Reck 1941b: 832; Pritchard and Baker 1955: 133, figs 96-99;

Ehara 1955: 180, figs 9-11.

Panonychus citri: Ehara 1956c: 500 (in part); Ehara and Ashihara 1993: 60, fig. 31. Tetranychus mytilaspidis (nec Riley): Banks 1900: 71.

Females of the citrus red mite Panonychus citri are bright red in color and provided with strong, red tubercles that bear the dorsal setae. The females are distinguished from those of $P$. ulmi by the color of the dorsal tubercles and the relative lengths of setae $\mathrm{L} 4$ and $\mathrm{C} 4$ (cf. key). Panonychus citri can be separated from $P$. mori and $P$. osmanthi by the shape of the aedeagus. Non-diapausing species.

Hosts. In Japan: citrus, pear, persimmon, Japanese holly (llex crenata), viburnum, Taxus cuspidata var. nana, etc. One of the most serious pests of citrus in the world.

Distribution. Honshu, Shikoku, Kyushu, Okinawa Island; Korea, China, Hainan Island, Taiwan, Thailand, Malaysia, Philippines, India, Pakistan, Iran, Georgia, Armenia, Turkey, U.K., Europe, Africa, U.S.A., Mexico, Central America, South America, Hawaii, Australia, New Zealand, etc. 
18. Panonychus osmanthi Ehara and Gotoh, 1996

(Fig. 39)

Panonychus osmanthi Ehara and Gotoh, 1996: 18, figs 1-8, 12-23. [Type loc: Ryugasaki, Ibaraki Pref.; type host: Osmanthus fragrans var. aurantiacus]

Females of Panonychus osmanthi are very similar to those of $P$. citri but differ in having setae L3 noticeably shorter than C3. In the latter species, setae L3 are slightly shorter than or as long as L3. Moreover, $P$. osmanthi is characterized by the aedeagus turning upward distally at a smaller angle to the ventral margin of the shaft (ca. $47^{\circ}$ - ca. $63^{\circ}$ ) than in P. citri (ca. $67^{\circ}$ - ca. $78^{\circ}$ ).

Hosts. Osmanthus.

Distribution. Honshu, Kyushu.

\section{Genus Sasanychus Ehara, 1978}

Panonychus (Sasanychus) Ehara, 1978: 88.

Sasanychus: Ehara and Gotoh 1987: 375.

Type species: Panonychus (Sasanychus) akitanus Ehara, 1978, by original designation.

Female: Body slender. Dorsal idiosomal setae not set on tubercles. Opisthosoma with transverse striae on dorsocentral area. Two pairs of para-anal setae. Empodium claw-like, with 3 pairs of proximoventral hairs all similar in length and set at nearly right angle with empodial claw. Two sets of duplex setae on tarsus I adjacent. Tibia I with 9 tactile setae; tibia II with 8 tactile setae.

Key to the Species of Sasanychus in Japan (Males)

1. Tarsus Il with 3 tactile setae and 1 solenidion proximal to duplex setae akitanus

Tarsus II with 1 tactile seta and 1 solenidion proximal to duplex setae pusillus

\section{Sasanychus akitanus (Ehara, 1978)}

(Figs 40-43)

Panonychus (Sasanychus) akitanus Ehara, 1978: 88, figs 1-11. [Type loc.: Nishisenboku, Akita Pref.; type host: Sasa sp.(a bamboo grass)]

Sasanychus akitanus: Ehara and Gotoh 1987: 376; Ehara and Gotoh 1993b: 66, fig. 34.

The female is dark green (dark reddish green in diapausing female). In the female, seta P2 is about $130 \mu \mathrm{m}$ long, the longest among the dorsal idiosomal setae; setae $\mathrm{H}, \mathrm{C} 1, \mathrm{C} 2, \mathrm{C} 3, \mathrm{~L} 1, \mathrm{~L} 2$, and $\mathrm{L} 3$ are more than $100 \mu \mathrm{m}$. Tarsus II of the male bears three tactile setae and one solenidion proximal to the duplex setae. The aedeagus is distinctive in that the distal upward portion is slightly sigmoid and has a truncate 


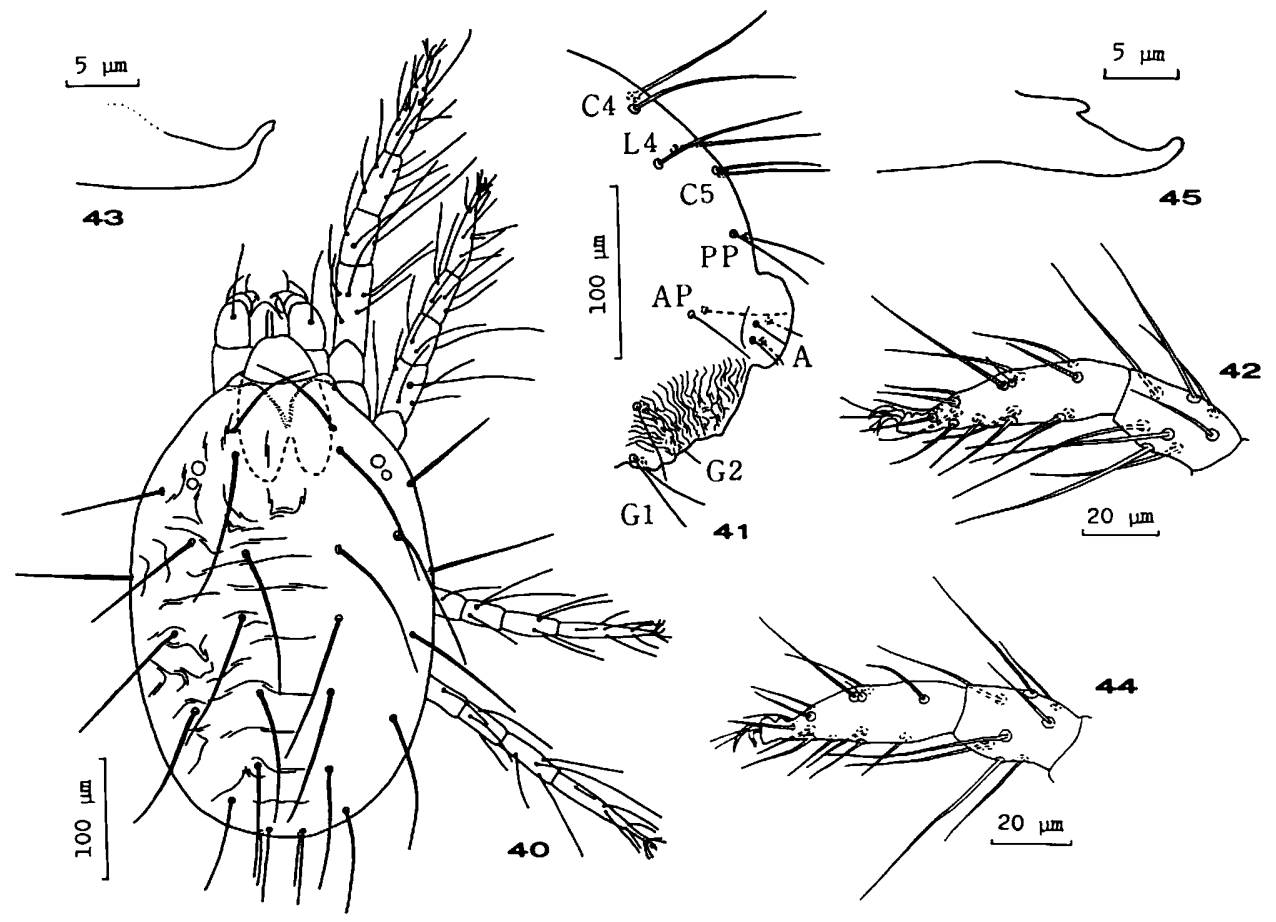

Figs 40-43. Sasanychus akitanus. 40, dorsum (우); 41, lateral view of caudal portion ( 우); 42, tarsus and tibia II $\left(\sigma^{7}\right) ; 43$, aedeagus. Figs 44, 45. Sasanychus pusillus $\left(\sigma^{7}\right) .44$, tarsus and tibia II; 45 , aedeagus.

tip, and the shaft is smooth dorsally.

Host. Sasa senanensis.

Distribution. Hokkaido, Honshu.

20. Sasanychus pusillus Ehara and Gotoh, 1987

(Figs 44, 45)

Sasanychus pusillus Ehara and Gotoh, 1987: 377, figs 9-12; Ehara and Gotoh 1993b: 66, fig. 35. [Type loc.: Takaoka, Tomakomai, Hokkaido; type host: Sasa apoiensis]

The body is smaller than in S. akitanus. The female is blackish green (dark reddish green when depositing its diapausing eggs). Seta P2 of the female is about $104 \mu \mathrm{m}$ long; none of the other dorsal setae are more than $100 \mu \mathrm{m}$. Tarsus II of the male has one tactile seta and one solenidion proximal to the duplex setae. The aedeagus is characterized by the distal portion being not undulate and ending in a round tip, and the dorsal margin of the shaft bearing a prominent process. The eggs lack a dorsal stipe, whereas those of $S$. akitanus have a distinct dorsal stipe (Ehara and Gotoh 1987).

Host. Sasa apoiensis. 
Distribution. Hokkaido.

\section{Genus Schizotetranychus Trägårdh, 1915}

Schizotetranychus Trägårdh, 1915: 277.

Type species: Tetranychus schizopus Zacher, 1913, by original designation.

Female opisthosoma with transverse or longitudinal striae on anterior portion of dorcocentral area and with transverse striae on posterior portion. Two pairs of para-anal setae. Empodium claw-like, bifurcate, appendant hairs present or absent. Two sets of duplex setae on tarsus I distal and adjacent. Summer females pale greenish yellow in most species.

This genus differs from Yezonychus in having 10 pairs of dorsal opisthosomal setae instead of nine pairs. The nine species now known from Japan are assigned to two species groups.

Key to the Species Groups of Schizotetranychus in Japan (Females)

1. Opisthosoma with transverse striae on anterior portion of dorsocentral area $\cdots . .$. schizopus species group

Opisthosoma with longitudinal striae on anterior portion of dorsocentral area $\cdots$ celarius species group

\section{schizopus species group}

Exemplar species: Tetranychus schizopus Zacher, 1913.

Female opisthosoma with transverse striae on anterior portion of dorsocentral area. Distal segment of palpus with 5 setae ( 3 tactile setae and 2 cupathidia) in addition to dorsal sensillum (solenidion) and spinneret (sometimes absent).

Key to the Species of the schizopus Species Group in Japan (Females)

1. Tibia II with 5 tactile setae

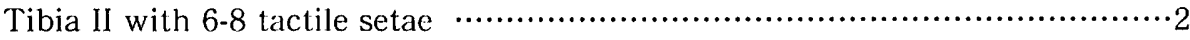

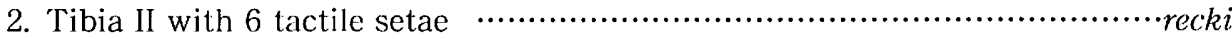

Tibia II with $7-8$ tactile setae

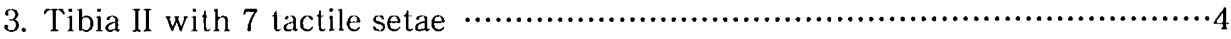

Tibia II with 8 tactile setae …….........................................................5

4. Dorsocentral opisthosomal setae not reaching to bases of setae next behind $\cdots . .$.

brevisetosus

Dorsocentral opisthosomal setae reaching to bases of setae next behind ............

leguminosus

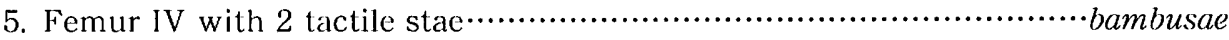

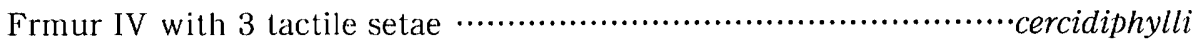




\section{Schizotetranychus schizopus (Zacher, 1913)}

(Figs 46, 48)

Tetranychus schizopus Zacher, 1913: 40, fig. 4. [Type loc.: Dahlem, Germany; type host: willow]

Schizotetranychus schizopus: Trägårdh 1915: 162; Geijskes 1939: 313, figs 1, 12, 13;

Pritchard and Baker 1955: 240, figs 192, 193; Ehara 1957: 15, figs 1-12; Ehara and Saito 1993: 84, fig. 45.

This species is distinctive among the Japanese members of the schizopus species group in having five pairs of tactile setae on tibia II. The aedeagus gradually narrows distally and curves dorsad, forming a terminal knob which bears a small anterior projection and a much longer posterior projection; the dorsal margin of the shaft is slightly longer than the length of the knob. The palpus of the male is devoid of a spinneret.

Hosts. In Japan: willow.

Distribution. Hokkaido, Honshu, Shikoku, Kyushu; China, Georgia, Armenia, U.K.,

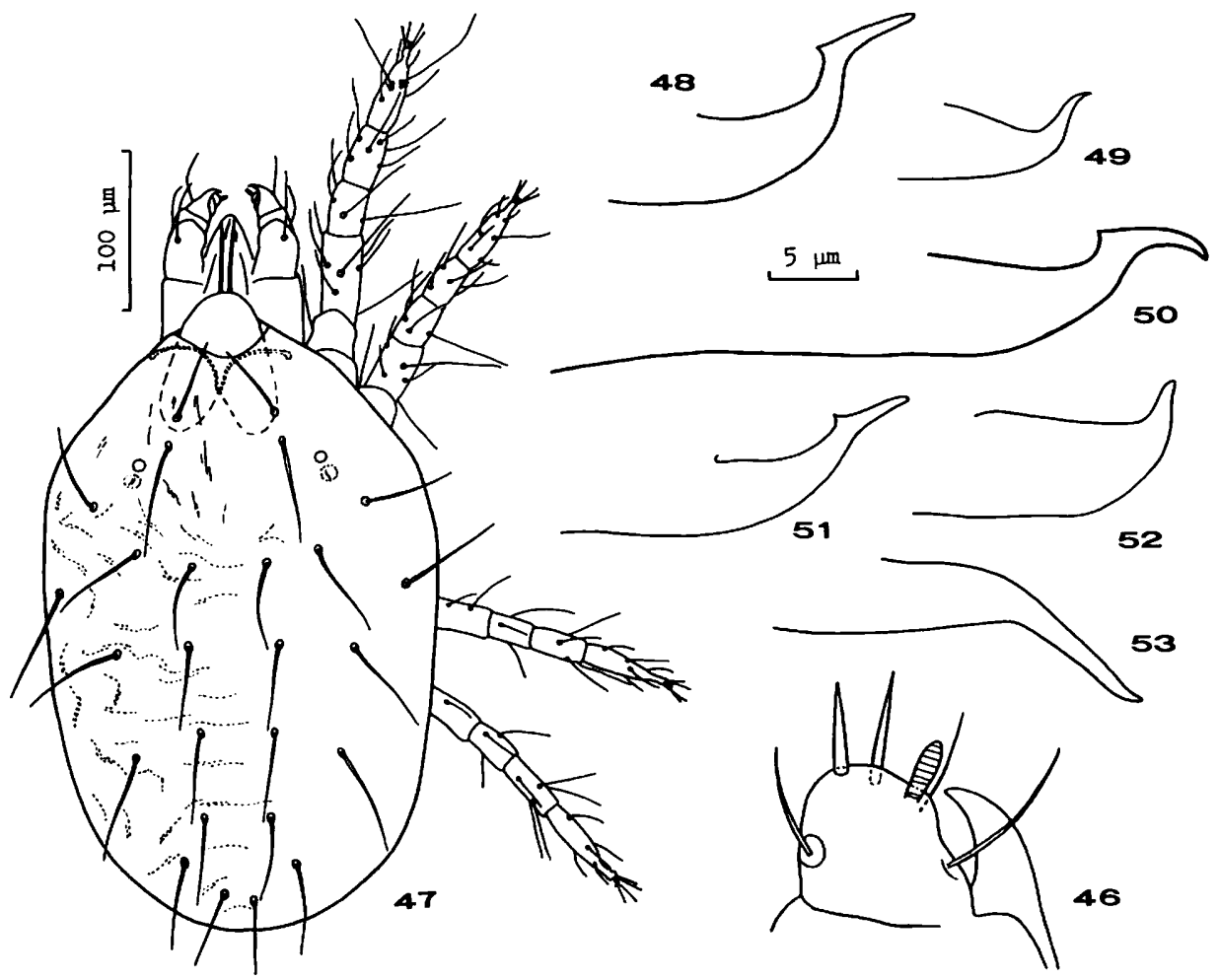

Fig. 46. Schizotetranychus schizopus ( $\left.\sigma^{7}\right)$, distal segment of palpus. Fig. 47. Schizotetranychus leguminosus ( + +), dorsum. Figs 48-53. Aedeagi (all at same magnification). 48, Schizotetranychus schizopus; 49, S. recki; 50, S. brevisetosus; 51, S. leguminosus; 52, S. bambusae; 53, S. cercidiphylli. 
Europe, U.S.A.

22. Schizoletranychus recki Ehara, 1957

(Fig. 49)

Schizotetranychus recki Ehara, 1957: 20, figs 25-35; Ehara and Saito 1993: 86, fig. 46.

[Type loc.: Sapporo, Hokkaido; type host: sasa bamboo (bamboo grass)]

In the female the dorsocentral opisthosomal setae are approximately as long as the distances to the bases of the setae next behind. Tibia II bears six tactile setae. The aedeagus strongly bends dorsad to form a gently sigmoid distal portion.

Hosts. Bamboo and bamboo grass.

Distribution. Hokkaido, Honshu, Shikoku, Kyushu.

\section{Schizoletranychus brevisetosus Ehara, 1989}

(Fig. 50)

Schizotetranychus brevisetosus Ehara, 1989a: 28, figs 1-12. [Type loc.: Miwa-cho, Kyoto Pref.; type host: Quercus glauca]

The body of the female is dorsoventrally depressed and reddish purple to dark red. The dorsal idiosomal setae acutely taper to a very slender distal end; most of them do not reach to the bases of the setae next behind. The aedeagus bends dorsad to form a sickle-shaped distal portion; the terminal knob is slightly more than one half as long as the dorsal margin of the shaft.

Hosts. Quercus glauca, Q. sp.

Distribution. Honshu, Kyushu.

\section{Schizotetranychus leguminosus Ehara, 1973}

(Figs 47, 51)

Schizotetranychus leguminosus Ehara, 1973: 224, figs 1-12; Wang 1981: 59, figs 44, 45; Tseng 1990: 106, figs 282-292. [Type loc.: Ishikari, Hokkaido: type host: Maackia amurensis var. buergeri]

The dorsocentral opisthosomal setae of the female are about as long as the distances to the bases of the setae next behind. The male palpus lacks a spinneret. The aedeagus is provided with a sickle-shaped distal portion; the terminal knob is approximately one half as long as the dorsal margin of the shaft.

Hosts. In Japan: Maarckia amurensis var. buergeri, Pueraria lobata, Wisteria sinensis.

Distribution. Hokkaido, Honshu, Kyushu; Korea, China, Taiwan. 
Schizotetranychus bambusae Reck, 1941 a: 449, figs 1-5; Bagdasarian 1957: 136, fig. 64; Ehara 1973: 229, figs 25-36; Wang 1981: 65, figs 52, 53; Ma et al. 1984: 126, fig. 8 (38) (copies of figures from Ehara 1973). [Type loc.: Georgia; type host: bamboo]

Schizotetranychus (Schizotetranychus) bambusae: Reck 1948a: 375, figs 11,23, 39; Reck 1948b: 451 .

This species is characterized by having femur IV with two tactile setae. The aedeagus bends dorsad to form a small, gradually narrowing distal portion which is devoid of a terminal knob.

Hosts. Bamboo.

Distribution. Hokkaido, Honshu; Korea, China, Hainan Island, Georgia.

\section{Schizotetranychus cercidiphylli Ehara, 1973}

(Fig. 53)

Schizotetranychus cercidiphylli Ehara, 1973: 227, figs 13-24. [Type loc.: Sapporo, Hokkaido; type host: Cercidiphyllum japonicum]

This species is easily distinguished from S. bambusae by having femur IV with three tactile setae and by the shape of the aedeagus. In S. cercidiphylli the aedeagus gently curves caudoventrally to form a slender, nearly straight distal portion.

Host. Cercidiphyllum japonicum.

Distribution. Hokkaido, Honshu.

\section{celarius species group}

Schizotetranychus celarius complex Ehara, 1989b: 359.

Exemplar species: Stigmaeopsis celarius Banks, 1917.

Body dorsoventrally depressed. Female opisthosoma with longitudinal striae on anterior portion of dorsocentral area. Distal segment of palpus with 4 setae ( 2 tactile setae and 2 eupathidia) in addition to dorsal sensillum (solenidion) and spinneret. Tibia II with 5 tactile setae.

In the previously known Japanese members of this group, the distal segment of palpus is provided with four setae. However, McGregor (1950) and Pritchard and Baker (1955) illustrated five setae on this segment in Schizotetranychus celarius, while Banks (1917) did not mention the number of palpal setae in the original description of Stigmaeopsis celarius.

Key to the Species of the celarius Species Group in Japan (Females)

1. Setae P2 approximately as long as distance between bases of P2 
Setae P2 shorter than distance between bases of P2 celarius

2. Distance between bases of setae $\mathrm{Cl}$ about twice as long as distance between

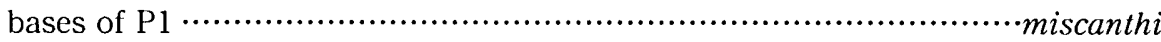

Distance between bases of setae $\mathrm{C} 1$ about 1.5 times as long as distance between bases of P1 longus

Stigmaeopsis celarius Banks, 1917: 196, pl. 15, figs 9, 11. [Type loc.: Oneco, Florida; type host: Bambusa metake]

Schizotetranychus celarius: McGregor 1950: 308, pl. 19; Pritchard and Baker 1955: 249, figs 205-207; Ehara 1957: 18, figs 13-24; Wang 1981: 56, figs 40, 41 ; Ehara and Saito 1993: 78, fig. 42.

This mite is tentatively determined as $S$. celarius. It is characterized by having setae P2 shorter than distance between their bases.

Hosts. Bamboo and bamboo grass.

Distribution. Hokkaido, Honshu, Shikoku, Kyushu, Okinawa Island; Korea, China, Taiwan, Europe, U.S.A., Hawaii.

28. Schizotetranychus miscanthi Saito, 1990

(Fig. 58)

Schizotetranychus miscanthi Saito, 1990: 389, figs 1-10, 21; Saito 1993: 80, fig. 43.

[Type loc.: Tsuyazaki, Fukuoka Pref.; type host: Miscanthus sinensis]

This species is distinctive in that setae P2 are approximately as long as the distance between their bases and the distance between setae $\mathrm{C} 1$ is about twice as long as the distance between setae P1.

Host. Miscanthus sinensis.

Distribution. Oshima-ōhshima Island (Hokkaido), Honshu, Shikoku, Kyushu, Okinawa I.

\section{Schizotetranychus longus Saito, 1990}

(Fig. 59)

Schizotetranychus longus Saito, 1990: 392, figs 11-20, 22; Saito 1993: 82, fig. 44. [Type loc.: Oyafuru, Ishikari, Hokkaido; type host: Sasa senanensis]

Schizotetranychus longus is distinguished by setae P2 being approximately as long as the distance between them, and by the distance between setae $\mathrm{C} 1$ being about 1.5 times as long as the distance between P1.

Hosts. Bamboo grass (Sasa senanensis, S. kurilensis, etc.) and bamboo.

Distribution. Hokkaido, Honshu, Shikoku, Kyushu. 


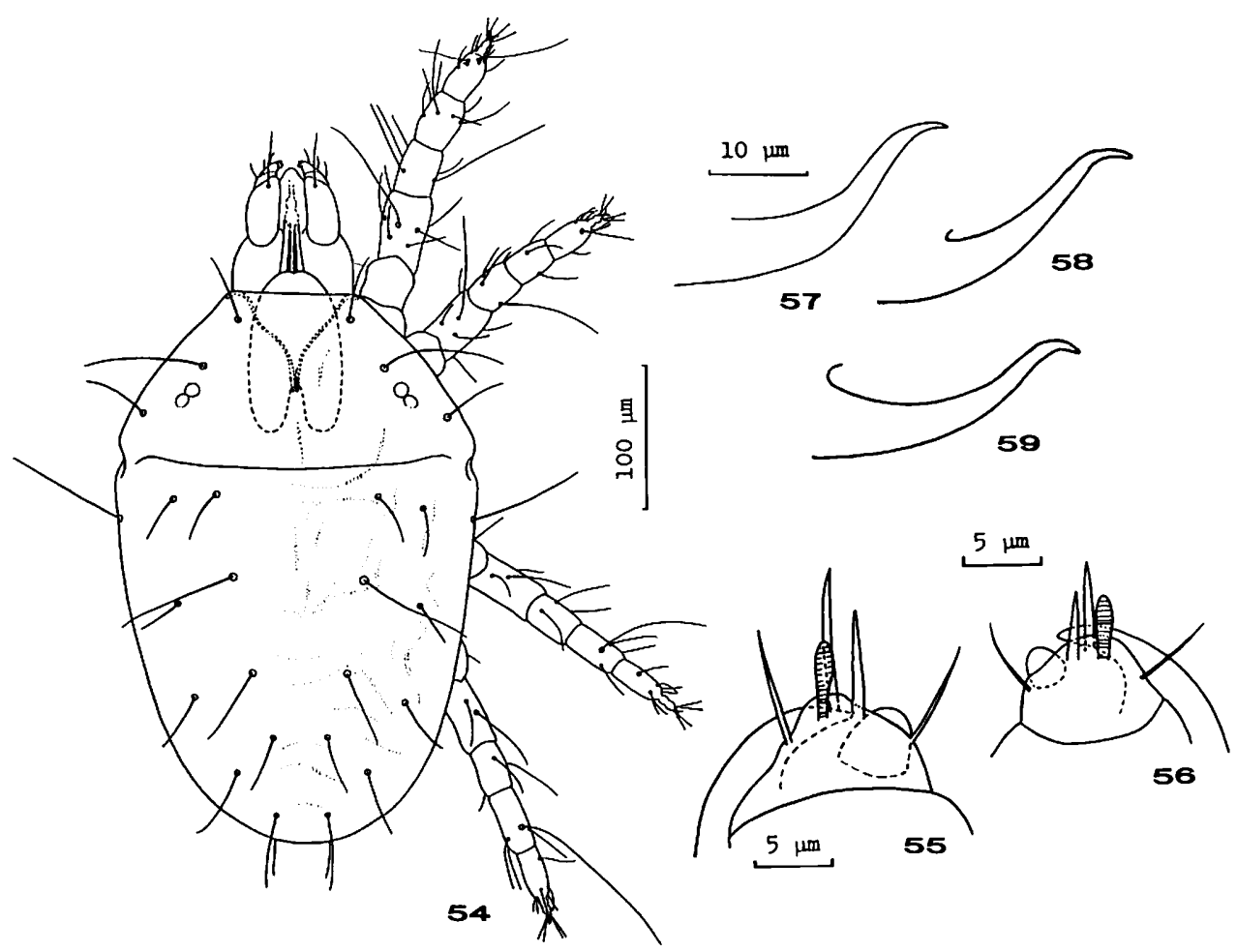

Figs 54-57. Schizotetranychus celarius. 54, dorsum (ㅇ ); 55, distal segment of palpus (ㅇ ); 56, ditto

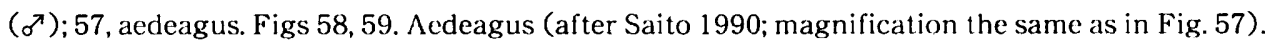
58 , Schizotetranychus miscanthi; 59, S. longus.

\section{Genus Yezonychus Ehara, 1978}

Yezonychus Ehara, 1978: 90.

Type species: Yezonychus sapporensis Ehara, 1978, by original designation.

Opisthosoma bearing 9 pairs of dorsal setae; setae L4 absent. Dorsocentral area of opisthosoma with transverse striae. Two pairs of para-anal setae. Empodium clawlike, bifid, without proximoventral hairs. Duplex setae on tarsus I distal, adjacent. Tibia II with 6 tactile setae.

This genus is known only from the type species.

\section{Yezonychus sapporensis Ehara, 1978}

(Figs 60-66)

Yezonychus sapporensis Ehara, 1978: 90, figs 12-23; Ehara and Saito 1993: 88, fig. 47.

[Type loc.: Hokkaido Univ. campus, Sapporo, Hokkaido; type host: Sasa senanensis] 


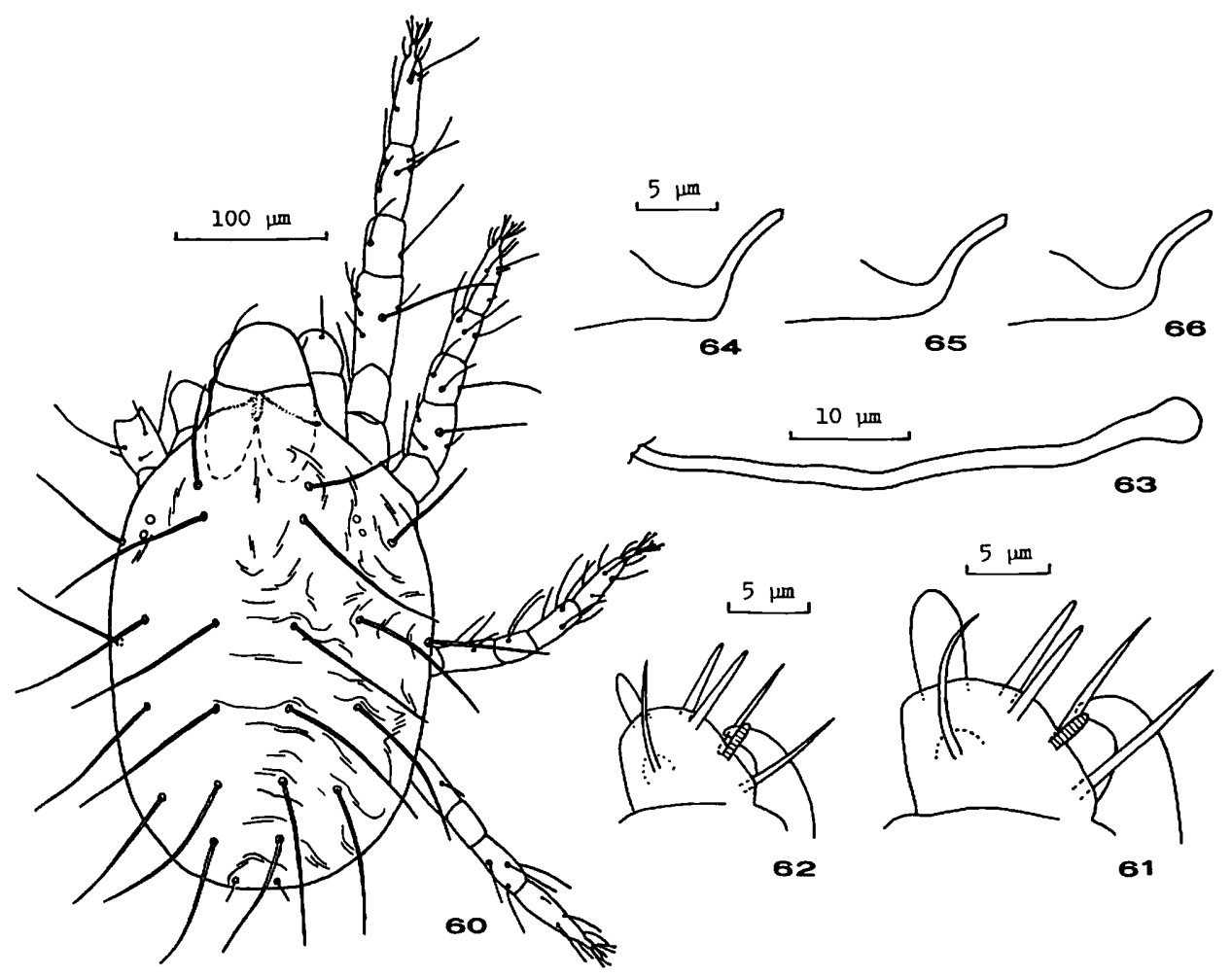

Figs 60-66. Yezonychus sapporensis. 60, dorsum ( + ); 61, distal segment of palpus ( + ) ; 62, ditto $\left(\sigma^{7}\right) ; 63$, peritreme ( +9$) ; 64-66$, aedeagi (the same magnification).

The female is pale yellow to pale greenish yellow (bright red in overwintering female). The aedeagus turns dorsad to form a slender, sigmoid distal portion.

Hosts. Bamboo grass (Sasa senanensis, S. apoiensis, Sasamorpha borealis), Shibataea kumasaca.

Distribution. Hokkaido, Honshu.

Genus Eotetranychus 0udemans, 1931

Eotetranychus Oudemans, 1931b: 224.

Type species: Trombidium tiliarium Hermann, 1804, by original designation.

Opisthosoma with transverse striae on dorsocentral area. Two pairs of para-anal setae. Empodium split into 3 pairs of ventrally directed hairs. Tarsus I with duplex setae distal and adjacent. Summer females of most species pale green or yellowish green, but rarely reddish.

Twenty-one species from Japan are now assigned to six species groups. 


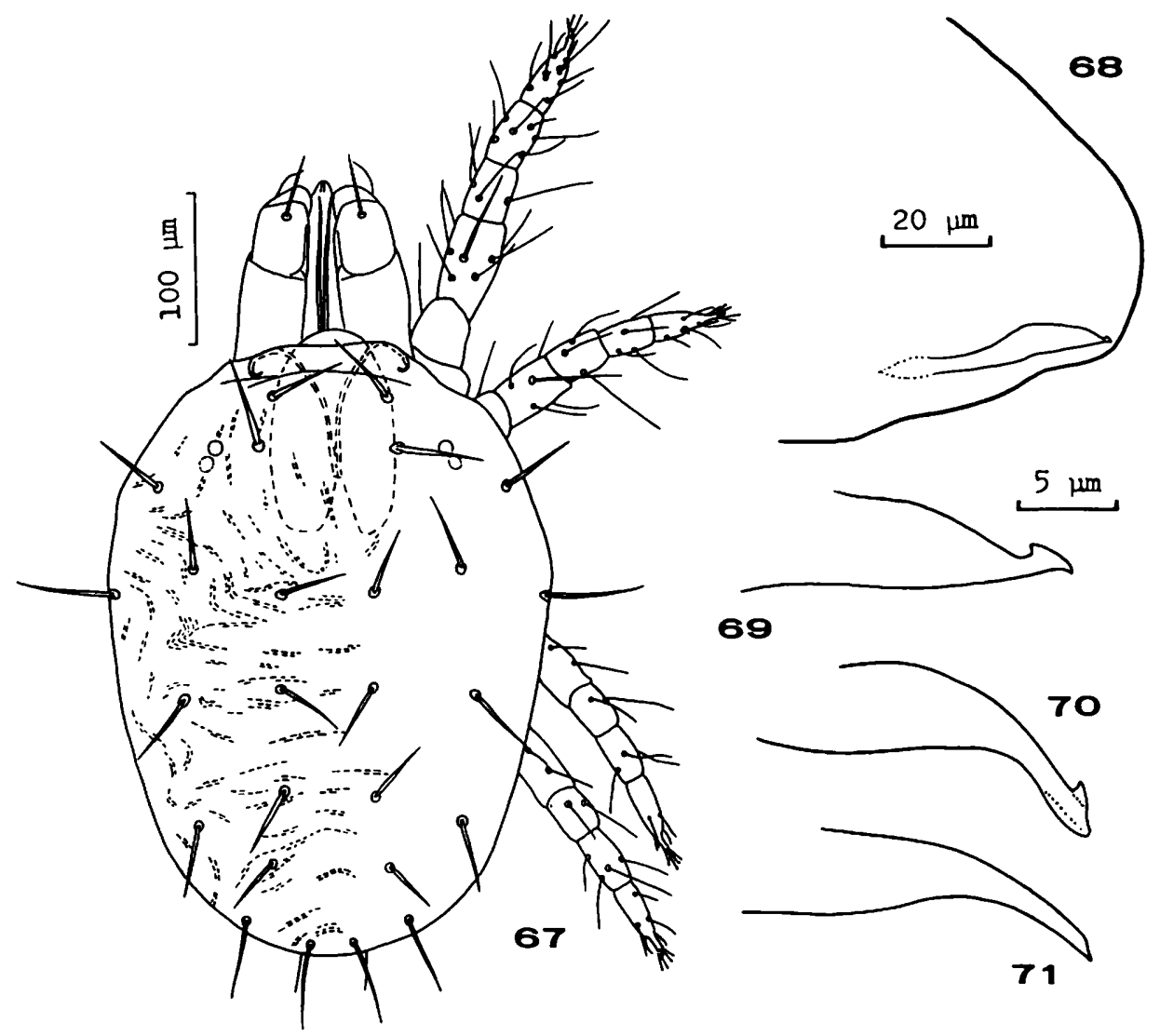

Figs 67-69. Eotetranychus shii. 67, dorsum ( + ); 68, 69, aedeagus. Figs 70, 71. Aedeagus (magnification the same as in Fig. 69). 70, Eotetranychus uchidai; 71, E. boreus.

Key to the Species Groups of Eotetranychus in Japan (Females)

1. Tibia II with 6 tactile setae clitus species group Tibia II with 7-8 tactile setae 2

2. Tibia II with 7 tactile setae uchidai species group Tibia II with 8 tactile setae ...3

3. Striae anterior to genital flap transverse …..............willamettei species group

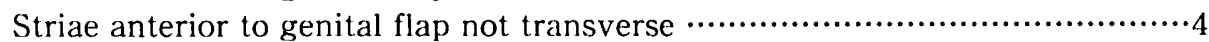

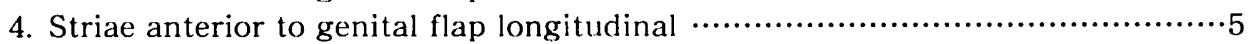
Striae anterior to genital flap irregular ….....................pallidus species group

5. Striae of genital flap transverse ….............................hicoriae species group Striae of genital flap longitudinal on anterior portion and transverse on posterior -sexmaculatus species group 
clitus species group

Clitus Group Pritchard and Baker, 1955: 169.

Exemplar species: Eotetranychus clitus Pritchard and Baker, 1955.

Tibia II with 6 tactile setae.

\section{Eotetranychus shii Ehara, 1965}

(Figs 67-69)

Eotetranychus shii Ehara, 1965: 618, figs 1-14; Ehara and Gotoh 1993b: 68, fig. 36. [Type loc.: Matsuyama, Ehime Prel.; type host: Castanopsis cuspidata (=Shiia sieboldii)]

The female of this species is distinct in that the body is dorsoventrally depressed and most of the dorsal idiosomal setac are shorter than the distances between their bases. The aedeagus gradually narrows posteriorly to form a terminal knob which bears a very short neck; the termination of the knob is caudoventrally directed, and the ventral margin of the shaft and knob is nearly straight.

Host. Castanopsis cuspidata.

Distribution. Honshu, Shikoku.

\section{uchidai species group}

Exemplar species: Eotetranychus uchidai Ehara, 1956.

Tibia II with 7 tactile setae.

Key to the Species of the uchidai Species Group in Japan (Females)

1. Peritreme nearly straight

uchidai

Peritreme hooked distally boreus

\section{Eotetranychus uchidai Ehara, 1956}

(Figs 5,70$)$

Eotetranychus uchidai Ehara, 1956b: 139, figs 1-10. [Type loc.: Sapporo, Hokkaido; type host: Ulmus japonica (=Ulmus davidiana var. japonica)]

This species is characterized by the nearly straight peritremes and the shape of the aedeagus. The aedeagus downcurves posteriorly to form a nearly straight distal portion which ends in a dorsally angulate knob.

Hosts. Japanese elm (Ulmus japonica), Zelkova serrata.

Distribution. Hokkaido, Honshu; Korea, China, Russia. 
33. Eotetranychus boreus Ehara, 1969

(Fig. 71)

Eotetranychus boreus Ehara, 1969a, 16, figs 1-17; Wang 1981: 68, fig. 54; Ma et al. 1984:

133, fig. 8 (44) (copies of figures from Ehara 1969a) [Type loc.: Sapporo, Hokkaido; type host: apricot]

This species differs from E. uchidai in the distally hooked peritremes and the shape of the aedeagus. The aedeagus gently downcurves posteriorly to form a slender, nearly straight distal portion. The spinneret on the male palpus is subconical, but considerably variable in shape.

Hosts. In Japan: apricot, Japanese apricot, plum.

Distribution. Hokkaido, Honshu; China.

\section{willamettei species group}

Willamettei Group Tuttle, Baker and Abbatiello, 1976: 37 (in part), fig. 71.

Exemplar species: Tetranychus willamettei McGregor, 1917.

Tibia II with 8 tactile setae. Genital flap in female with transverse striae; area anterior to genital flap with transverse striae.

Key to the Species of willamettei Species Group in Japan

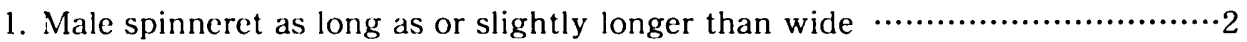

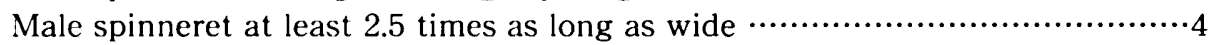

2. Aedeagus downcurved posteriorly, without terminal knob …........................

Aedeagus downcurved posteriorly, with terminal knob …..............geniculatus

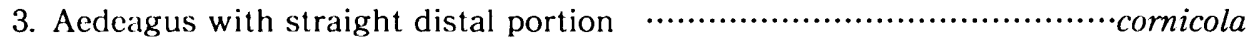

Aedeagus with sigmoid distal portion …......................................... lewisi

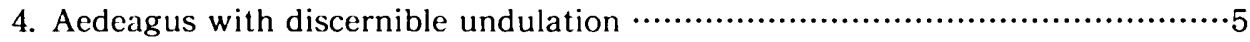

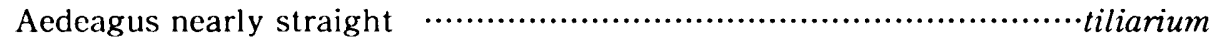

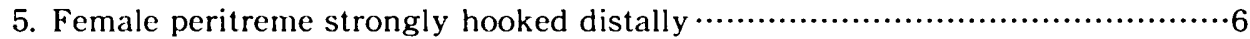

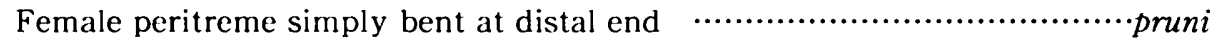

6. Aedeagus weakly undulate ….......................................................querci

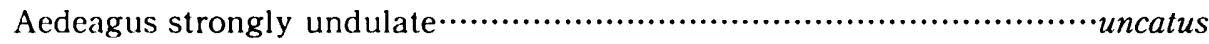

34. Eoletranychus geniculatus Ehara, 1969

(Figs 72, 74)

Eotetranychus geniculatus Ehara, 1969a: 19, figs 30-42; Wang 1981: 75, fig. 64; Ma et al. 1984: 140, fig. 8 (54) (copies of figures from Ehara 1969a). [Ty pe loc.: Morioka, Iwate Pref.; type host: strawberry]

The aedeagus is distinctive in that the shaft gradually bends ventrad to form a 


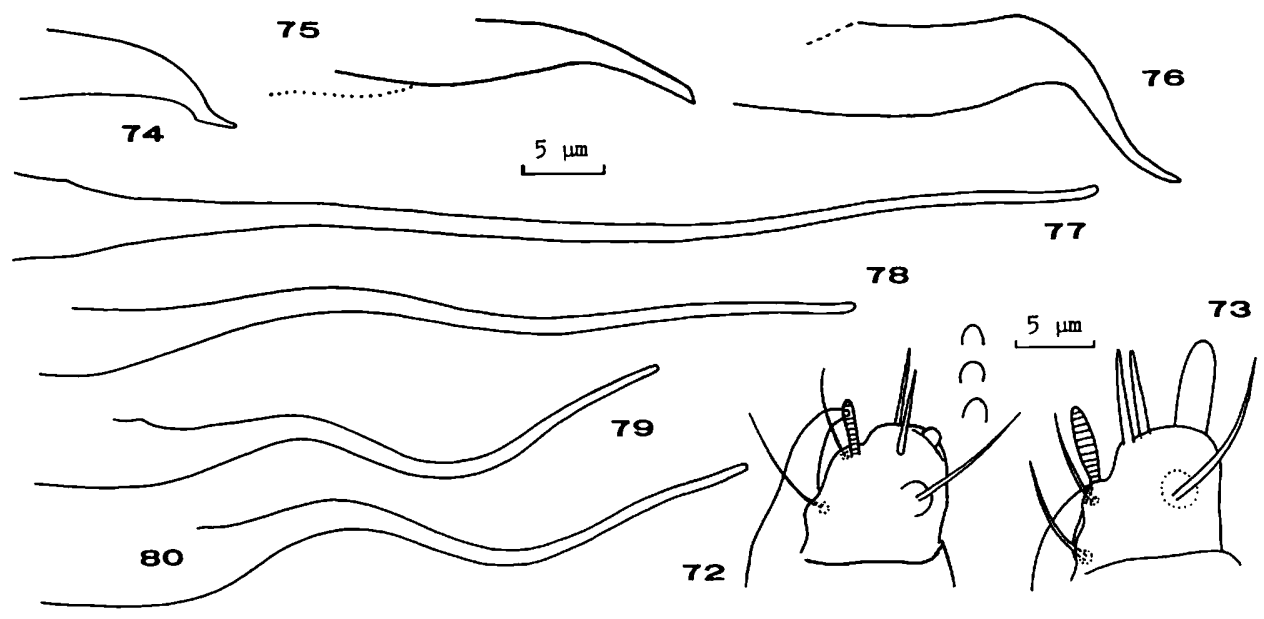

Fig. 72. Eotetranychus geniculatus $\left(\sigma^{7}\right)$, distal segment of palpus, showing variation of spinneret (magnification the same as in Fig. 73). Fig. 73. Eoletranychus tiliarium $\left(\sigma^{7}\right)$, distal segment of palpus. Figs 74-80. Aedeagi (all at same magnification). 74, Eotetranychus geniculatus; 75, E. cornicola; 76, E. lewisi; 77, E. tiliarium; 78, E. querci; 79, E. pruni; 80, E. uncatus.

slender terminal knob which bears an inconspicuous anterior angulation and a longer, blunt-ended posterior projection. The peritreme of female is more or less tobacco-pipe-shaped distally.

Hosts. In Japan: strawberry, grape.

Distribution. Honshu; China, Hainan Island.

35. Eotetranychus cornicola Ehara, 1989

(Fig. 75)

Eotetranychus cornicola Ehara, 1989a: 31, figs 13-23. [Type loc.: Kuriyagawa, Morioka, Iwate Pref.; type host: Cornus controversa]

The aedeagus is characterized by the shaft bending downward at a slight angle to form a slender, caudally directed distal portion which ends in an acute tip. The peritreme of female is straight distally and ends in a dilated portion.

Host. Cornus controversa.

Distribution. Hokkaido, Honshu.

36. Eotetranychus lewisi (McGregor, 1943)

(Japanese name: Ruisu-hadani)

(Figs 76, 81-91)

Tetranychus lewisi McGregor, 1943: 127, pl. 13; McGregor 1950: 288, pl. 6, fig. 11.

[Type loc.: Corona, California; type host: fruits of navel orange] 

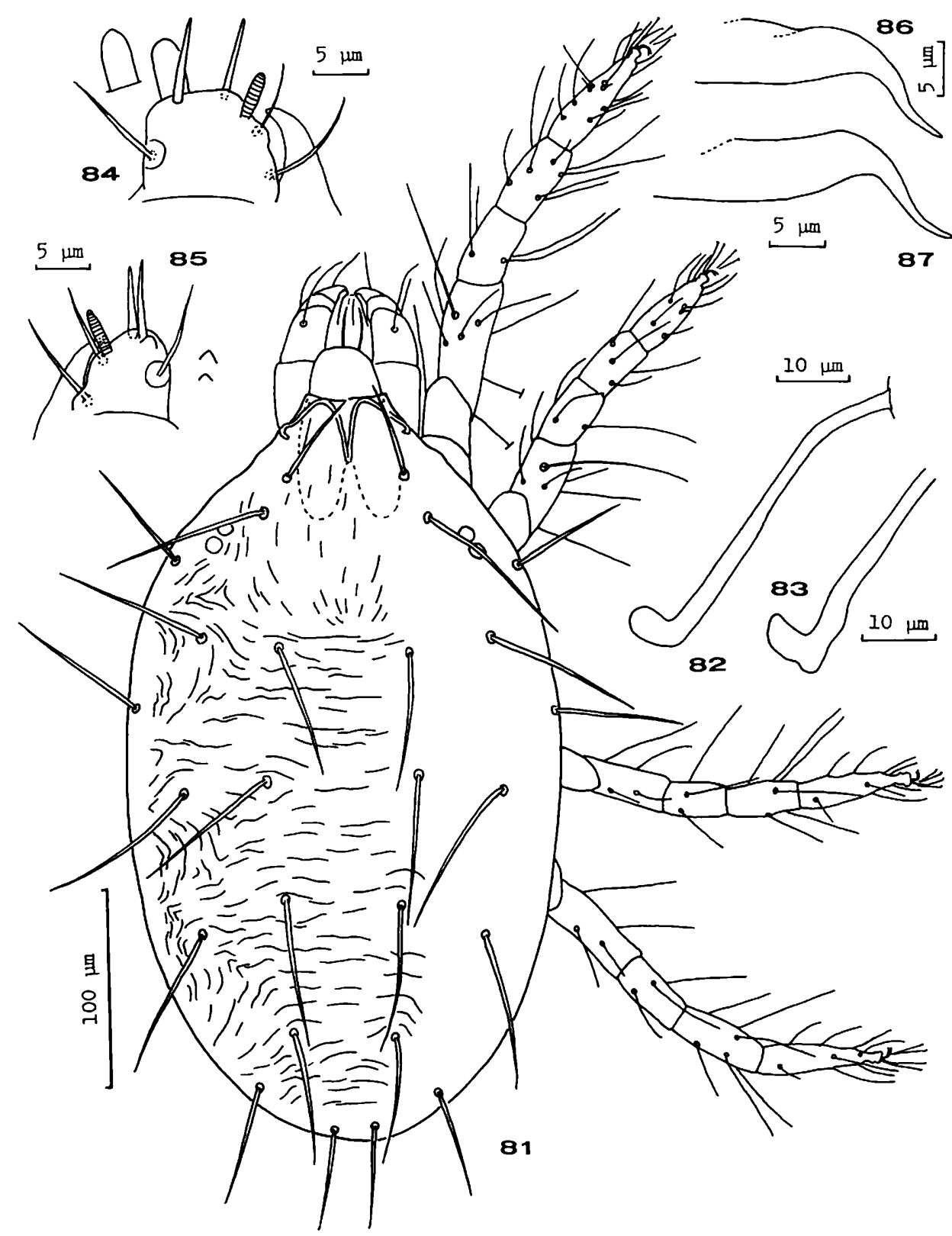

Figs 81-87. Eotetranychus lewisi. 81, dorsum (ㅇ ); 82, 83, peritreme (ㅇ ); 84, distal segment of palpus (우), with another spinneret; 85 , ditto $\left(\sigma^{7}\right)$, showing variation of spinneret; 86,87 . aedeagus. 


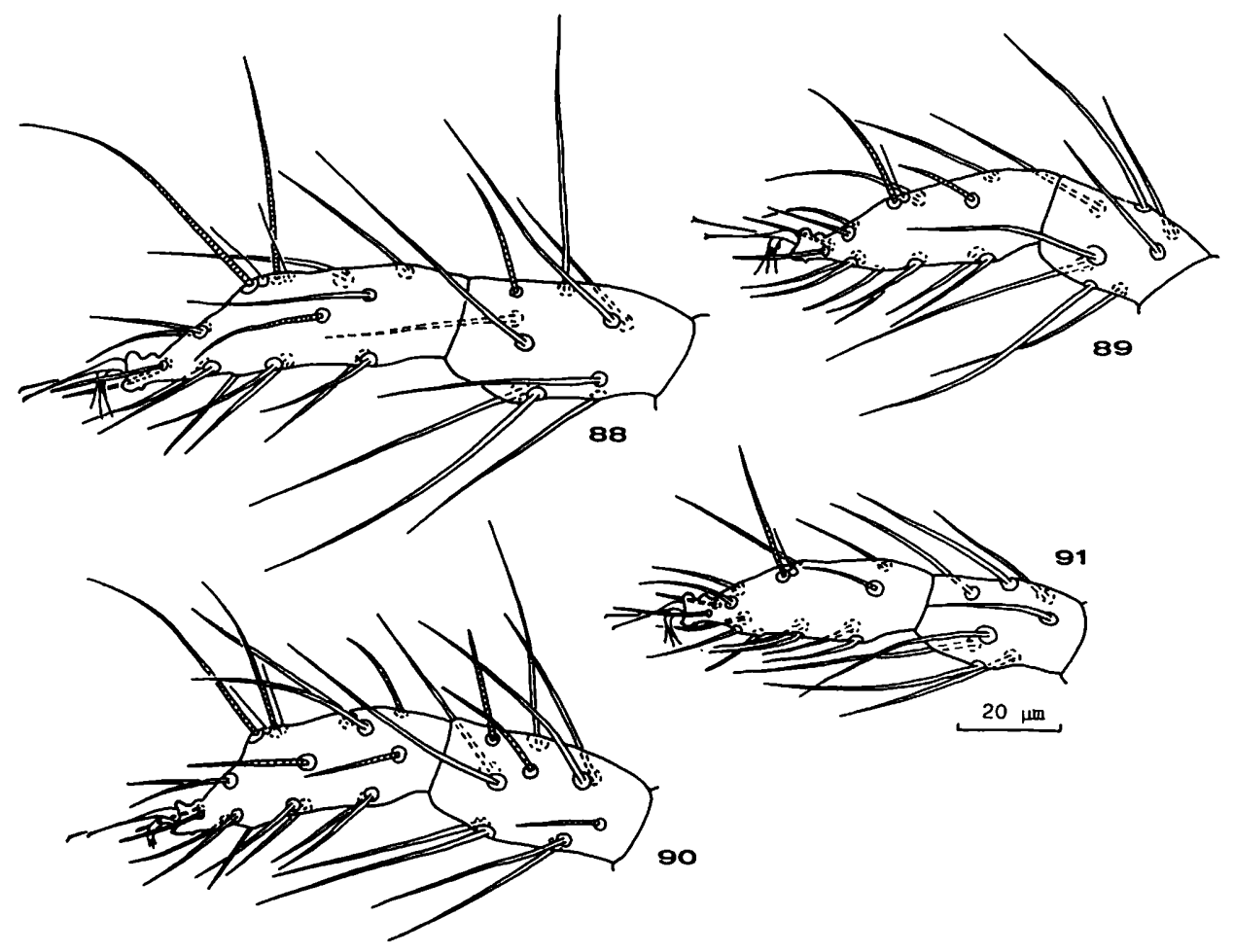

Figs 88-91. Eotetranychus lewisi. 88, tarsus and tibia I (우); 89, tarsus and tibia II (우); 90, tarsus and tibia I $\left(\sigma^{7}\right)$; 91 , tarsus and tibia II $\left(\sigma^{7}\right)$.

Eotetranychus lewisi: Pritchard and Baker 1955: 205, figs 157-159; Baker and Pritchard 1962: 318, figs 57-61; Meyer 1974: 203, figs 851-856; Baker and Tuttle 1994: 171, fig. 112; Ehara et al. 1998: 228, figs 1, 2.

Female. Body, including rostrum, 470 long, 243 wide, pale yellowish green or pale yellow, with dark lateral spots. Idiosoma with dorsal setae slender, pubescent, longer than distances between bases of setae next behind. Striae of opisthosoma transverse on dorsocentral area; lobes on dorsal opisthosomal striae broader than tall. Peritreme L-shaped distally. Genital flap with transverse striae; area immediately anterior to it with transverse striae. Palpus with spinneret about twice as long as broad; dorsal sensillum fusiform, slightly shorter than spinneret. Numbers of setae and solenidia (in parentheses) on leg segments: femora 10-7-4-4, genua 5-5-4-4, tibiae 9(1)-8-6-7, tarsi 14(1) +2 dupl.-13(1) +1 dupl.-10(1)-10(1). Tarsus I with 5 tactile setae and 1 solenidion proximal to proximal set of duplex setae; tarsus II with 3 tactile setae and 1 solenidion proximal to duplex setae, and 1 tactile seta near duplex setae. Empodium split into 3 pairs of hairs as usual.

Male. Body, including rostrum, 336 long, 165 wide. Aedeagus downcurved in middle at nearly $45^{\circ}$ to form the weakly sigmoid distal portion, which is gradually tapering. Spinneret minute, subconical, approximately as long as broad. Numbers of 
setae and solenidia (in parentheses) on leg segments: femora 10-7-4-4, genua 5-5-4-4, tibiae 9(3)-8-6-7, tarsi 13(3) +2 dupl.-13(1) +1 dupl.-10(1)-10(1). Tarsus I with 4 tactile setae and 3 solenidia proximal to proximal set of duplex setae; tarsus II with 3 tactile setae and 1 solenidion proximal to duplex setae, and 1 tactile seta near duplex setae. Empodium I split into 3 pairs of digits, middle pair the strongest, dorsal pair slightly shorter, ventral pair very fine, often invisible.

Collection data. Three $\sigma^{7} \delta^{7}$ and 7 우 우, Kōnan, Aichi Pref., 1-V-1998 (K. Itoh), on poinsettia in vinyl house; $3 \sigma^{7} \sigma^{7}$ and 11 ㅇ ㅇ , 6-V-1998, other data as for the above; 9 $\sigma^{7} \sigma^{7}$ and 27 \& 9 , Gose, Nara Pref., 2-IX-1997 (Y. Kunimoto), on poinsettia in vinyl house.

Host. In Japan: poinsettia (Euphorbia pulcherrima).

Distribution. Honshu; Africa, U. S. A., Mexico, Central and South America, Hawaii.

Remarks. Eotetranychus lewisi is well known to be a pest of many plants, particularly citrus, poinsettia, papaya, and castor bean. This species has very recently been recorded from Japan (Ehara et al. 1998). It is probable that it was accidentally introduced together with poinsettia imported from Mexico or elsewhere.

\section{Eotetranychus tiliarium (Hermann, 1804)}

(Figs 73, 77)

Trombidium tiliarium Hermann, 1804: 42. [Type loc.: Strasbourg, France; type host: Tilia sp.]

Eotetranychus tiliarium: Pritchard and Baker 1955: 178; Reeves 1963: 33, figs 49-57; Ehara 1970: 132, figs 1-4, 13-23.

Eotetranychus tiliarius: Rota 1962: 96, Figs XXI-XXIII.

Eotetranychus tiliarium is readily recognized by its extremely long, nearly straight aedeagus. The female is pale yellow.

Hosts. In Japan: Alnus japonica, A. hirsuta var. sibirica, Crataegus jozana.

Distribution. Hokkaido; Korea, China, Georgia, Turkey, U.K., Europe, U.S.A.

38. Eotetranychus pruni (Oudemans, 1931)

(Fig. 79)

Tetranychus pruni Oudemans, 1931a: 195. [Type loc.: Germany; type host: Prunus domestica]

Eotetranychus pruni: Geijskes 1939: 31, fig. 20; Reeves 1963: 37, figs 72-75; Ehara 1970: 137, figs 8-10,33-42; Wang 1981:79, fig. 67; Ma et al. 1984: 135, fig. 8 (47) (copies of figures from Ehara 1970).

Schizotetranychus (Eotetranychus) pruni: Wainstein 1960: 182, figs 29, 30, 222-230.

Eotetranychus pomi Sepasgosarian 1955: 21, figs 1-10; Rota 1962: 102, figs XXIVXXVI.

The aedeagus of Eotetranychus pruni, as well as those of E. querci and E. uncatus, is very long, flagellate, and undulate near the middle. These three species are assigned to the carpini complex (Ehara 1970). The female of E. pruni is pale yellow, 
with the peritreme not $\mathrm{U}$-shaped distally but simply bent near the tip. The aedeagus is provided with a strong undulation.

Ilosts. In Japan: Quercus dentata and chestnut.

Distribution. Hokkaido, Honshu; China, Iran, Georgia, Turkey, U.K., Europe, Africa, U.S.A.

\section{Eotetranychus querci Reeves, 1963}

(Fig. 78)

Eotetranychus querci Reeves, 1963: 40, figs 88-97; Ehara 1970: 135, figs 5-7, 24-32;

Baker and Tuttle 1994: 184, fig. 122 (copies of figures from Reeves 1963). [Type loc.: Letchworth State Park, Mt. Morris, Wyoming County, New York; type host: Quercus palustris]

Eotetranychus querci belongs to the carpini complex bacause of the flagellate and undulate aedeagus (cf. E. pruni). This species is distinguishable from the other members of the complex by the strongly hooked peritreme of the female and by the weakly undulate aedeagus. The female is pale greenish yellow.

Host. In Japan: Tilia japonica.

Distribution. Honshu; U.S.A.

\section{Eotetranychus uncatus Garman, 1952}

(Fig. 80)

Eotetranychus uncatus Garman in Pritchard and Baker 1952: 263, pls 5, 6; Reeves 1963: 39, figs 76-80; Ehara 1970: 139, figs 11, 12, 43-50. [Type loc.: Amherst, Massachusetts; type host: apple leaves]

This species, being provided with a flagellate and sinuate aedeagus, is a member of the carpini complex. The species differs from the other members of the complex in the U-shaped peritreme of the female and the strongly undulate aedeagus. The female is pale greenish yellow.

Host. In Japan: Juglans ailanthifolia.

Distribution. Hokkaido, Honshu; China, India, Kazakhstan, Europe, U.S.A., Mexico, South America.

\section{pallidus species group}

Pallidus Group Tuttle, Baker and Abbatiello, 1976: 48, fig. 70.

Exemplar species: Tetranychus pallidus Garman, 1940.

Tibia II with 8 tactile setae. Genital flap in female with transverse striae; area anterior to flap with irregular striae.

Males of the three Japanese species attributed to this group are similar to each other in having the palpus devoid of a spinneret and in the shape of the aedeagus. 
Key to the Species of the pallidus Species Group in Japan

1. Female opisthosoma with dorsocentral setae noticeably longer than distances to

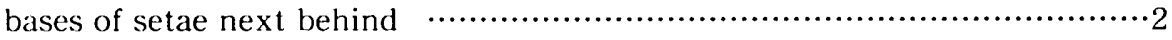

Female opisthosoma with dorsocentral setae approximately as long as distances

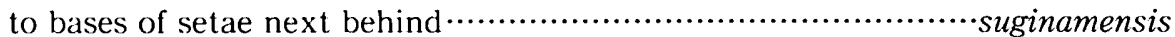

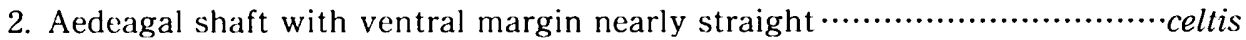

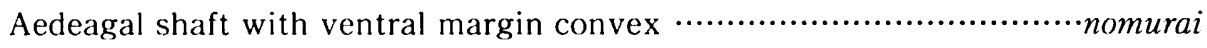

\section{Eotetranychus suginamensis (Yokoyama, 1932)}

(Fig. 93)

Tetranychus suginamensis Yokoyama, 1932: 231, pls 23, 24. [Type loc.: Suginami, Tokyo; type host: mulberry]

Eotetranychus suginamensis: Pritchard and Baker 1955: 200; Ehara 1956c: 501, figs 1-14; Wang 1981: 87, fig. 74; Ehara and Gotoh 1993b: 70, fig. 37.

Female of this species is characterized by the opisthosomal dorsocentral setae being approximately as long as the distances between the consecutive setae. The aedeagal shaft is provided with a concave dorsal margin and convex ventral margin; the distal portion of the aedeagus is sigmoid, tapering, and directed ventrocaudally. There is no spinneret on the male palpus.

Host. In Japan: mulberry.

Distribution. Hokkaido, Honshu, Okinawa Island; China, Taiwan, India.

\section{Eotetranychus celtis Ehara, 1965}

(Figs 92, 94)

Eotetranychus celtis Ehara, 1965: 620, figs 15-25; Ehara and Gotoh 1993b: 72, fig. 38.

[Type loc.: Kōchi, Kōchi Pref.: type host: Celtis sinensis var. japonica]

The dorsal idiosomal setae of the female are much longer than the distances between their bases. The aedeagus abruptly narrows to the middle and nearly perpendicularly bends ventrad to form a L-shaped, slender distal portion; the ventral margin of the shaft is nearly straight. The male palpus lacks a spinneret on the distal segment.

Hosts. In Japan: Celtis sinensis var. japonica, C. jessoensis, Aphananthe aspera.

Distribution. Honshu, Shikoku; China.

It is probable that a mite formerly recorded as $E$. celtis from Thailand (Ehara and Wongsiri 1975) does not belong to this species.

\section{Eotetranychus nomurai Ehara, 1989}

(Fig. 95)

Eotetranychus nomurai Ehara, 1989a: 35, figs 36-46. [Type loc.: Matsudo, Chiba Pref.; 


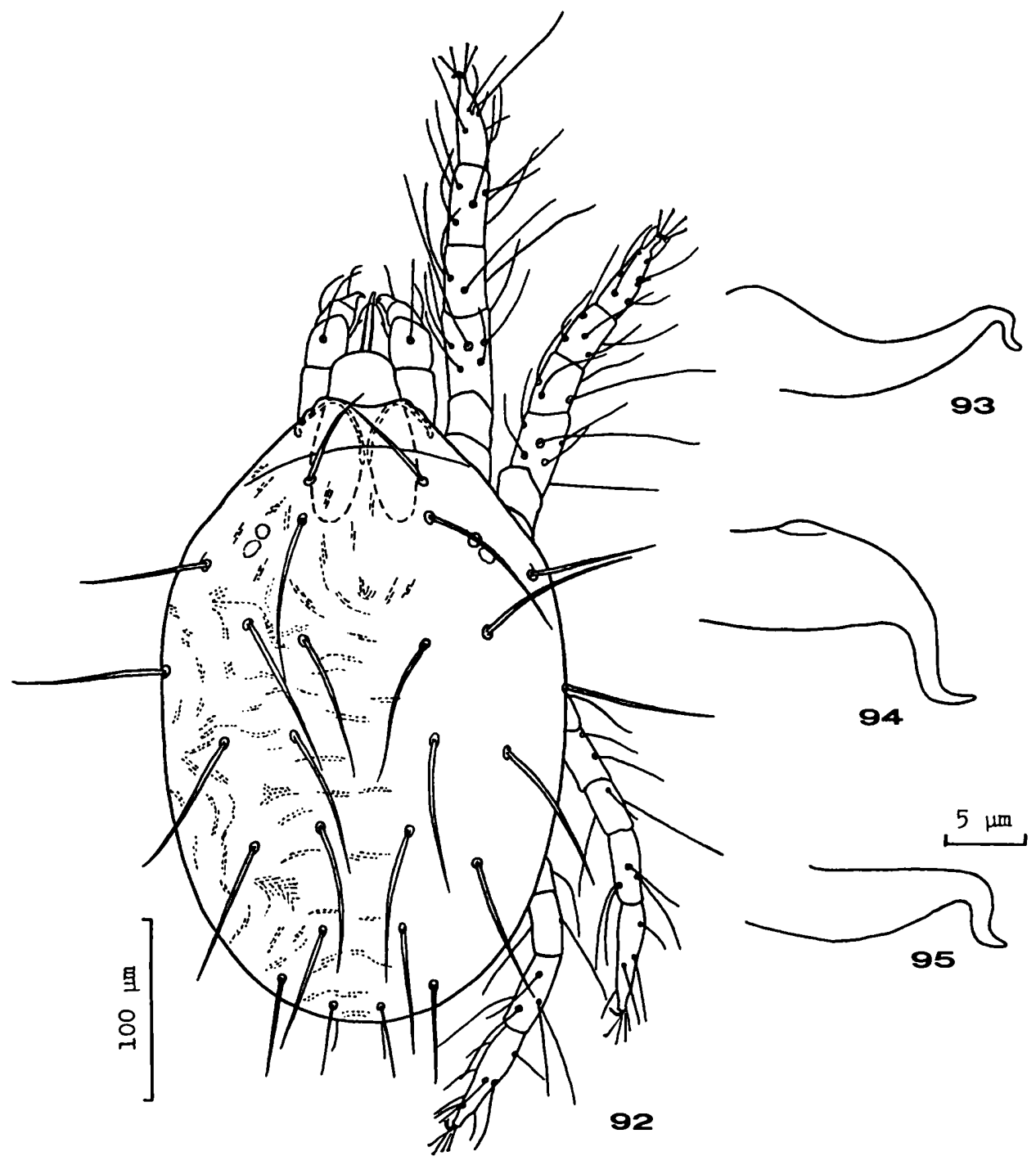

Fig. 92. Eotetranychus celtis ( + ), dorsum. Figs 93-95. Aedeagi (all at same magnification). 93, Eotetranychus suginamensis; 94, E. celtis; 95, E. nomurai.

type host: Aphananthe aspera]

The dorsal idiosomal setae of the female are much longer than the intervals between their bases. The aedeagus strongly downcurves posteriorly to form a slender, sigmoid distal portion; the dorsal margin of the shaft is nearly straight and the ventral margin is convex. The male palpus is devoid of a spinneret on the distal segment. 
Host. Aphananthe aspera.

Distribution. Ilonshu.

\section{hicoriae species group}

Hicoriae Group Tuttle, Baker and Abbatiello, 1976: 46 (in part), fig. 72.

Exemplar species: Tetranychus hicoriae McGregor, 1950.

Tibia II with 8 tactile setae. Genital flap in female with transverse striae; area anterior to flap with longitudinal striae.

Key to the Species of the hicoriae Species Group in Japan

1. Female palpus with spinneret approximately twice as long as wide $\cdots \cdots \cdots \cdots \cdots \cdot \cdots \cdot \cdots$ Female palpus with spinneret about 1.5 times as long as wide $\cdots \cdots \cdots \cdots \cdot \cdots \cdot$.....smithi

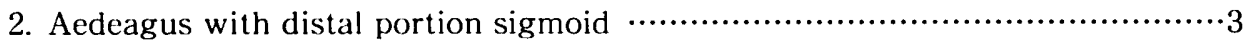

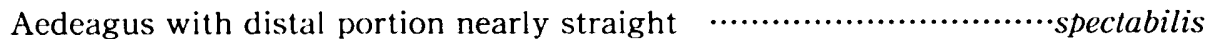

3. Aedeagal shaft with dorsal margin undulate, ventral margin strongly convex $\cdots$ tsugaruensis

Aedeagal shaft with dorsal margin practically straight, ventral margin gently

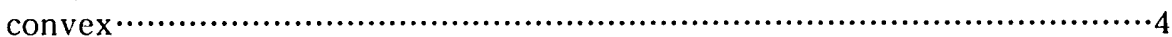

4. Empodium with distict mediodorsal spur …................................. rubricans

Empodium without mediodorsal spur …................................quercifoliae

44. Eotetranychus smithi Pritchard and Baker, 1955

(Figs 96, 97, 99)

Eotetranychus smithi Pritchard and Baker, 1955: 192, figs 149, 150; Ehara 1960: 234, figs 1-15; Wang 1981: 84, fig. 72; Ehara and Ashihara 1993: 74, fig. 39. [Type loc:: College Park, Maryland; type host: rambler rose]

The female of this species is red in color, in contrast to those of most members of Eotetranychus, which are pale greenish yellow or pale yellow. The female is also characterized by having the palpal spinneret about 1.5 times as long as wide. The aedeagus is distinctive in that the proximal portion is upturned and the distal portion is abruptly narrowed to form an undulate, caudally directed flagellum.

Collection data. Five $\sigma^{7} \sigma^{7}$ and 8 o +9 , Tsukuba, Ibaraki Pref., 7-VIII-1997 (K. Gomi), on Salix bakko.

Hosts. In Japan: grape, pear, strawberry, Rubus parvifolius, Salix bakko.

Distribution. Honshu, Kyushu; Korea, China, Taiwan, Philippines, Seychelles, Madagascar, U.S.A.

45. Eotetranychus spectabilis Ehara, 1987

(Fig. 100) 


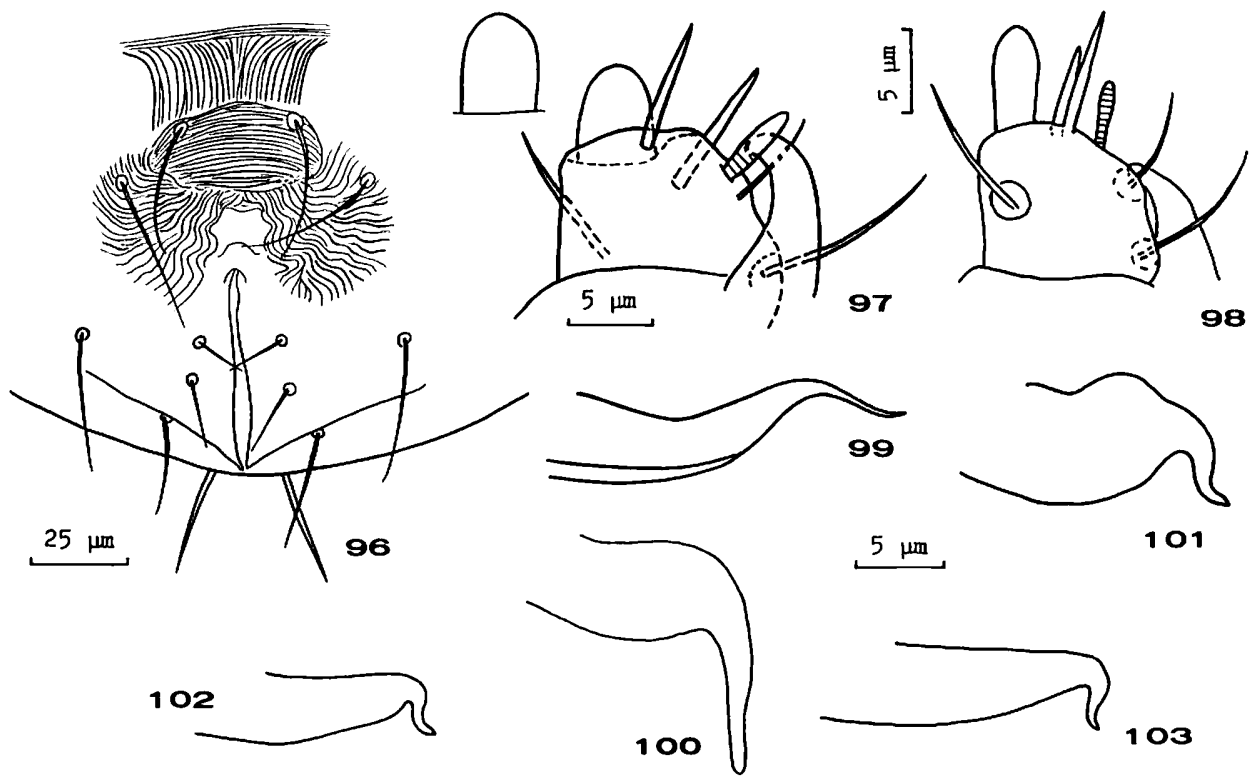

Figs 96, 97. Eotetranychus smithi ( + ). 96, venter of caudal portion of opisthosoma; 97, distal segment of palpus. Fig. 98. Eotetranychus quercifoliae ( 9 ), distal segment of palpus. Figs. 99-103. Aedeagi (all at same magnification). 99, Eotetranychus smithi; 100, E. speclabilis; 101, E. tsugaruensis; 102, E. quercifoliae; 103, E. rubricans sp. nov.

Eotetranychus spectabilis Ehara, 1987: 624, figs 1-13. [Type loc:: Botanical Garden,

Hokkaido Univ., Sapporo; type host: Acer platanoides]

The female is characterized by the dark red body color, differing from those of most species of Eotetranychus, which are pale greenish yellow or pale yellow. The aedeagus is downcurved posteriorly at a nearly right angle, forming a slender, almost straight distal portion. The chaetotaxic formulae of the legs in the original description are corrected as follows: female, femora 10-7-4-4, genua 5-5-4-4, tibiae 9(1)-8-6-7, tarsi 14(1)+2 dupl.-13(1)+1 dupl.-10(1)-10(1); male, femora 10-7-4-4, genua 5-5-4-4, tibiae 9(4)-8-6-7, tarsi 13(3)+2 dupl.-13(1)+ 1 dupl.-10(1)-10(1).

Hosts. Acer.

Distribution. Hokkaido, Honshu.

46. Eotetranychus tsugaruensis Ehara, 1989

(Fig. 101)

Eotetranychus tsugaruensis Ehara, 1989a: 33, figs 24-35. [Type loc.: Ochiai, Kuroishi, Aomori Pref.; type host: Cercidiphyllum japonicum]

The aedeagus of this species is distinctive in that the shaft is short and very broad and strongly downcurves posteriorly to form a sigmoid distal portion, the 
dorsal margin of the shaft is concave near the base, and the ventral margin is strongly convex. The spinneret on the male palpus is nipple-shaped, about as long as broad.

Host. Cercidiphyllum japonicum.

Distribution. Honshu.

47. Eoletranychus rubricans Ehara, sp. nov.

(Japanese name: Inushide-hadani)

(Figs 103-114)

Female. Body, including rostrum, 423 long, 260 wide, red in color. Dorsal setae of idiosoma pubescent, much longer than distance between their bases; lengths of setae $(\mathrm{n}=10): \mathrm{P} 168.5 \pm 0.7, \mathrm{P} 2108.7 \pm 0.9, \mathrm{P} 3$ 80.2 $\pm 0.6, \mathrm{H} 88.5 \pm 0.9, \mathrm{Cl} 95.6 \pm 0.5, \mathrm{C} 294.0$

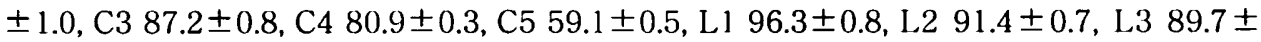
$0.7, \mathrm{~L} 471.1 \pm 0.6$. Opisthosoma with transverse striae on dorsocentral area; dorsal opisthosomal striae with lobes very variable in shape. Peritreme U-shaped distally. Genital flap with transverse striae; area immediately anterior to flap with longitudinal striae. Palpus with spinneret about twice as long as broad; dorsal sensillum fusiform, long and slender. Numbers of setae and solenidia (in parentheses) on leg segments: femora 10-7-4-4, genua 5-5-4-4, tibiae 9(1)-8-6-7, tarsi $14(1)+2$ dupl.$13(1)+1$ dupl.-10(1)-10(1). Tarsus I with 5 tactile setae and 1 solenidion proximal to proximal set of duplex setae; tarsus II with 3 tactile setae and 1 solenidion proximal to duplex setae, and 1 tactile seta near duplex setae. Empodia with distinct mediodorsal spur.

Male. Body, including rostrum, 329 long, 145 wide, pale yellowish green. Lengths of setae $(n=10)$ : PI 51.4 \pm 0.6 (49.9), P2 81.8 \pm 0.5 (82.8), P3 61.1 \pm 0.7 (61.0), H 68.4

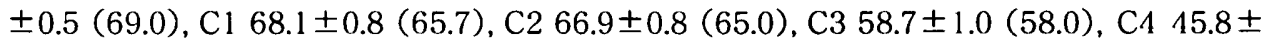

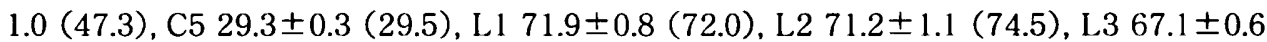
(67.5), L4 35.0 \pm 1.2 (35.4). Aedeagus very strongly downcurved posteriorly to form slender, sigmoid distal portion approximately $1 / 3$ as long as dorsal margin of shaft; bend in aedeagus acutely emarginate ventrally; dorsal and ventral margins of shaft nearly straight. Palpus lacking spinneret; dorsal sensillum well developed. Numbers of setae and solenidia (in parentheses) on leg segments: femora 10-7-4-4, genua 5-5-4-4, tibiae 9(4)-8-6-7, tarsi 13(3) + 2 dupl.-13(1) +1 dupl-10(1)-10(1). Tarsus 1 with 4 tactile setae and 3 solenidia proximal to proximal set of duplex setae; tarsus Il with 3 tactile setae and 1 solenidion proximal to duplex setae, and 1 tactile seta near duplex setae. Empodia with distinct mediodorsal spur.

Type series. Holotype: $\sigma^{7}$, Midori-ku, Chiba, Chiba Pref., 6-VII-1997 (T. Gotoh), on Carpinus tschonoskii. Paratypes: $9 \sigma \sigma$ and 17 우 9 , with the above data.

Remarks. Eotetranychus rubricans is near E. spinifer Wang, 1980 (China) in the presence of a distinct mediodorsal spur on each empodium. However, the aedeagus of the former is characterized by a nearly straight to slightly concave dorsal margin, whilst that of the latter has a strongly concave dorsal margin.

A Japanese species, E. quercifoliae (see below), is somewhat similar to $E$. rubricans in the shape of the aedeagus, but the empodia of quercifoliae are devoid of a mediodorsal spur. Females of E. rubricans are red in color, and its males are pale yellowish green (according to Gotoh, personal communication), while both sexes of 


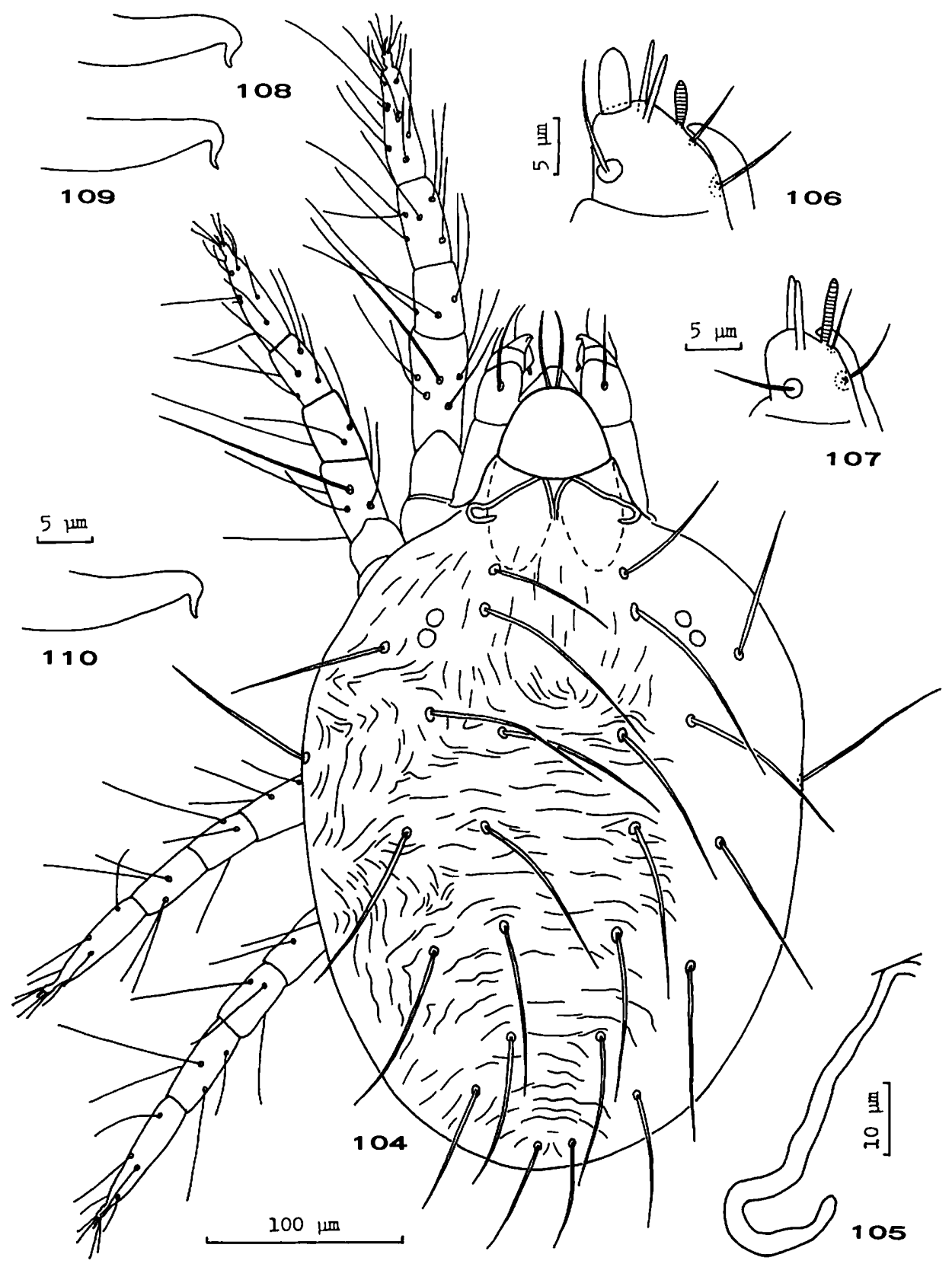

Figs 104-110. Eotetranychus rubricans sp. nov. 104, dorsum ( + ); 105, peritreme ( + ); 106, distal segment of palpus ( + ); 107, ditto ( $\sigma^{\top}$, holotype); 108-110, aedeagi (all at same magnification; 109, holotype). 


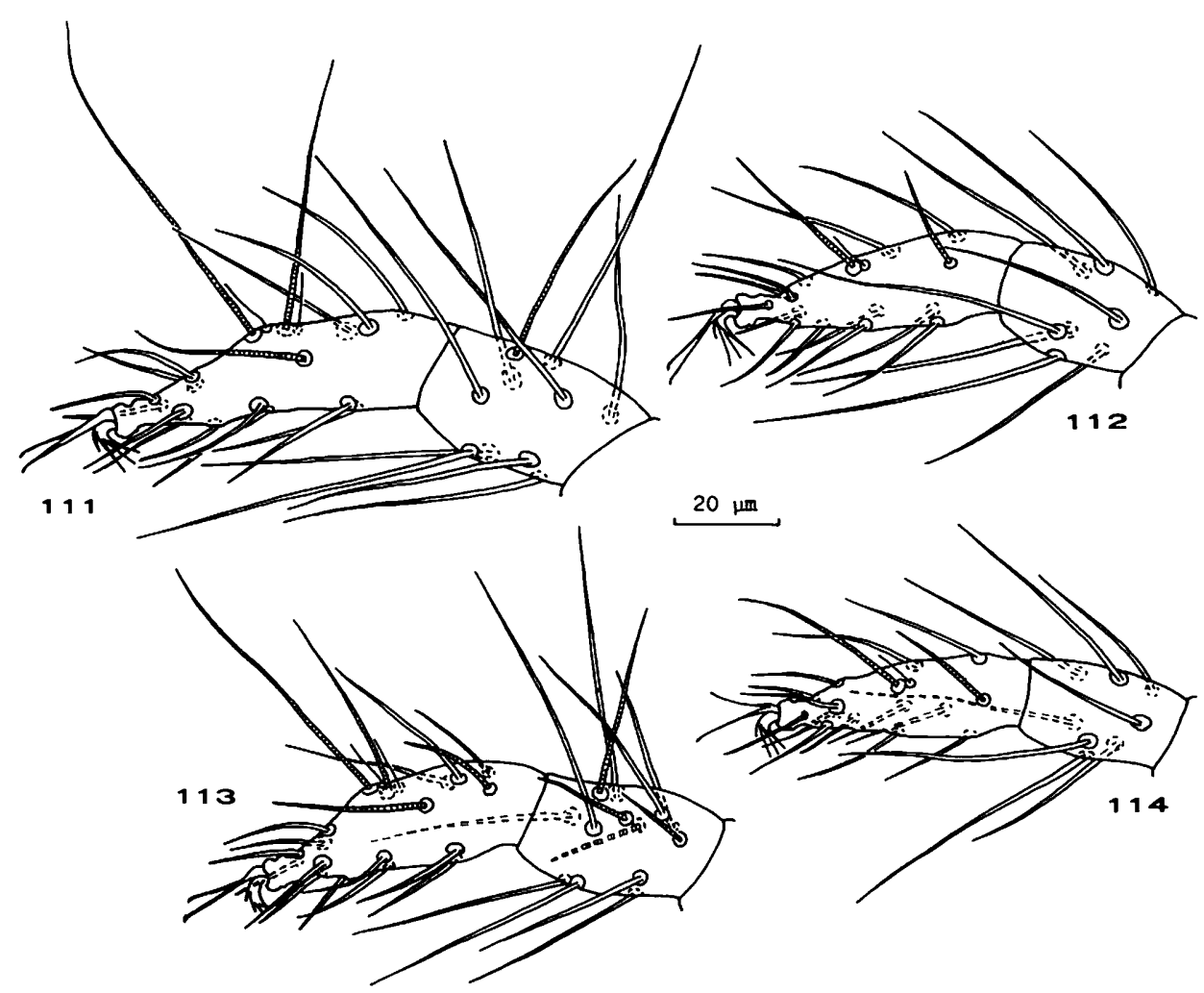

Figs 111-114. Eotetranychus rubricans sp. nov. 111, tarsus and tibia I ( ( + ); 113 , tarsus and tibia I ( $\sigma^{7}$, holotype); 114 , tarsus and tibia II ( $\sigma^{7}$, holotype).

quercifoliae are pale yellowish green.

Etymology. Referring to the red color of female body.

\section{Eotetranychus quercifoliae Ehara and Gotoh, 1997}

(Figs 98, 102)

Eotetranychus quercifoliae Ehara and Gotoh, 1997: 219, figs 1-10, 14-17. [Type loc.:

Tsukuba, Ibaraki Pref.; type host: Quercus serrata]

The aedeagus of Eotetranychus quercifoliae is distinct in that the sigmoid distal portion is approximately one third the length of the dorsal margin of the shaft. The spinneret on the male palpus is rudimentary or absent.

Host. Quercus serrata.

Distribution. Honshu. 


\section{sexmaculatus species group}

Sexmaculatus Group Tuttle, Baker and Abbatiello, 1976: 49, fig. 73.

Exemplar species: Tetranychus 6-maculatus [sic] Riley, 1890.

Tibia II with 8 tactile setae. Genital flap in female with longitudinal striae on anterior portion and transverse striae on posterior portion; area anterior to flap with longitudinal striae.

Key to the Species of the sexmaculatus Species Group in Japan

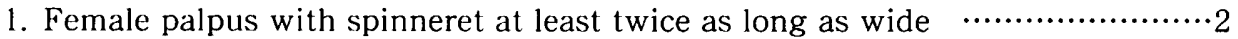

Female palpus with spinneret approximately as long as wide $\cdots . . . . . . .$. dissectus

2. Male palpus with subconical spinneret; aedeagus with posterior tip ventrally

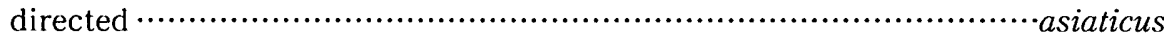

Male palpus with subcylindric spinneret; aedeagus with posterior tip slightly upcurved …....................................................................kankitus

49. Eotetranychus dissectus Ehara, 1987

(Figs 117-119)

Eotetranychus dissectus Ehara, 1987: 627, figs 14-27. [Type loc.: Botanical Garden, Hokkaido University, Sapporo; type host.: Acer mono]

The female is characterized by the dark red body color and by having the spinneret approximately as long as wide. The aedeagus is elongately triangular with its ventral margin practically straight and the dorsal margin nearly straight except for the basal portion, which is slightly curved. The chaetotaxic formulae in the original description are corrected as follows: female, femora 10-7-4-4, genua 5-5-4-4, tibiae 9(1)-8-6-7, tarsi 14(1) + 2 dupl.-13(1) + 1 dupl.-10(1)-10(1); male, femora $10-7-4$ or $5-4$ or 5 , genua $5-5-4-4$, tibiae $9(4)-8-6-7$, tarsi $13(3)+2$ dupl.-13(1) +1 dupl.-10(1)-10(1).

Hosts. Acer.

Distribution. Hokkaido, Honshu.

\section{Eotetranychus asiaticus Ehara, 1966}

(Figs 115, 116, 121)

Eotetranychus asiaticus Ehara, 1966b: 8, figs 5-13; Ehara 1969a: 18, figs 19-29; Tseng 1990: 56, figs 133-143; Ehara and Ashihara 1993: 76, fig. 40. [Type loc.: Tomigusuku, Okinawa Island; type host: Ficus erecta]

Eotetranychus sexmaculatus (nec Riley): Ehara 1956b: 142, figs 11-21; Wang 1981: 83, fig. 71; Ma et al. 1984: 133, fig. 8 (45) (copies of figures from Ehara 1966b, 1969a); Lee and Lee 1992: 47, fig. $1 \mathrm{G}$. 


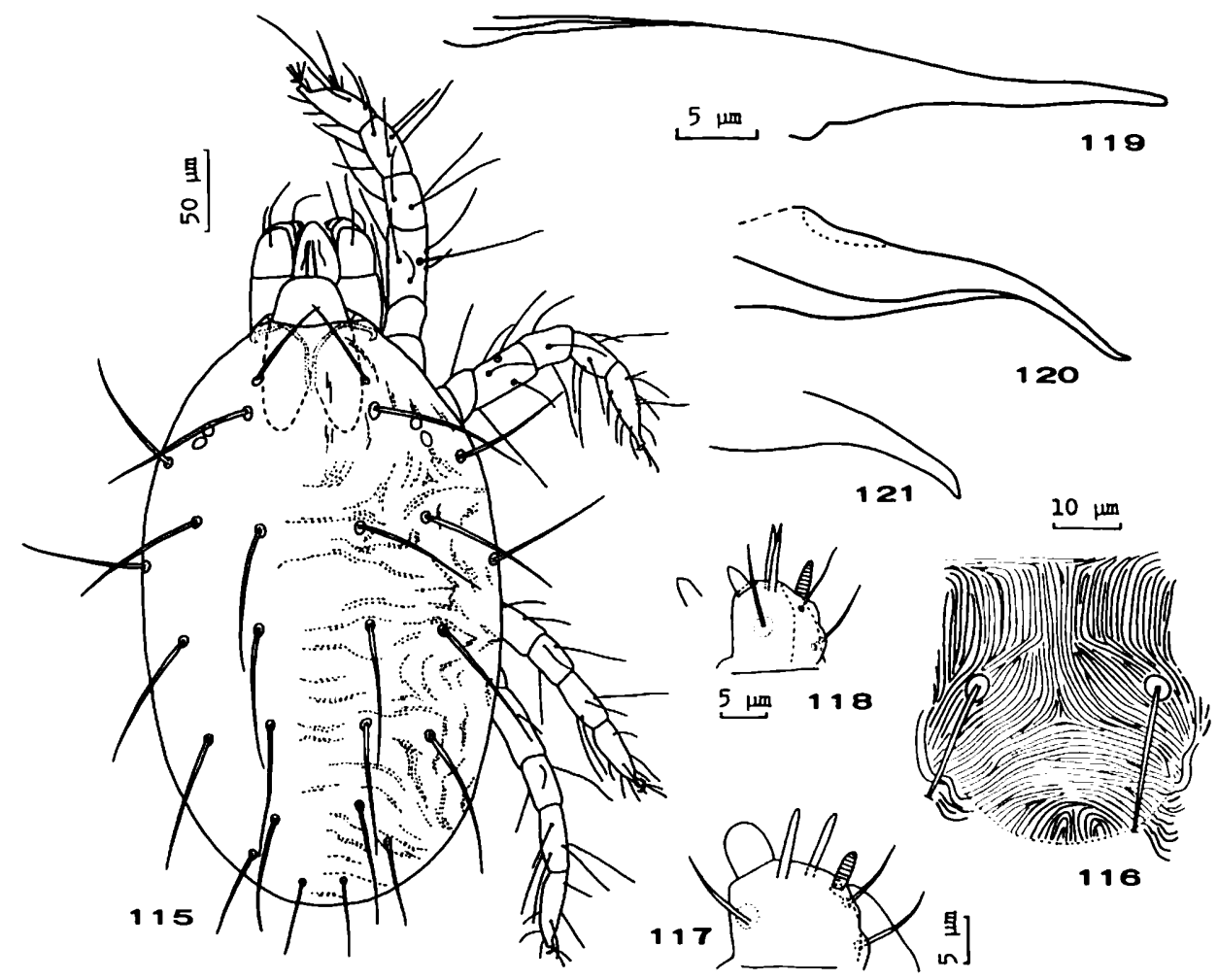

Figs 115, 116. Eotetranychus asiaticus ( + ). 115, dorsum; 116, pregenital and genital area. Figs 117-119. Eotetranychus dissectus. 117, distal segment of palpus ( + ); 118, distal segment of palpus $\left(\sigma^{7}\right)$, with another spinneret; 119, aedeagus. Figs 120,121 . Aedeagus (magnification the same as in Fig. 119). 120, Eotetranychus kankitus; 121, E. asiaticus.

The female is pale greenish yellow, with three (or irregular) dark spots along each side of the body. The spinneret on the female palpus is about twice as long as wide. The male spinneret is subconical but variable in shape, of ten approximately as long as wide. This species is somewhat similar to Eotetranychus sexmaculatus (Riley, 1890), a pest of citrus in California and Florida, in the shape of the acdeagus. However, the aedeagus of E. asiaticus is distinctive in that the middle portion is gently curved caudoventrally to form a very slender, practically straight distal portion, and the termination is more or less angulate and ventrally directed.

IIosts. In Japan: citrus, tea, persimmon, Ficus erecta, azalea (Rhododendron), camphor tree (Cinnamomum camphora), Lindera citriodora, spraque (Ternstroemia gymnanthera), Mallotus japonica.

Distribution. Honshu, Kyushu, Okinawa Island; Korea, China, Taiwan.

51. Eotetranychus kankitus Ehara, 1955

(Fig. 120) 
Eotetranychus kankitus Ehara, 1955: 178, figs 1-8; Ehara 1965: 623, figs 26-29; Wang 1981: 81, fig. 70; Ehara and Ashihara 1993: 76, fig. 41. [Type loc.: Hisatomo-mura, Ōsaki-shimojima Island, Hiroshima Pref.; type host: citrus]

The female is similar in color to that of Eotetranychus asiaticus, but differs from the latter in the two dark spots along each side of the body. The spinneret on the female palpus is about 2.5 times as long as wide. The male spinneret is about twice as long as wide. The aedeagus is distinctively downcurved near the middle at about $45^{\circ}$ to form a very slender, nearly straight distal portion, and the termination ends in a slightly upturned tip.

Hosts. In Japan: citrus.

Distribution. Honshu, Ōsaki-shimojima Island, Shikoku; China, Malaysia, India, Nepal.

\section{Genus Oligonychus Berlese, 1886}

Oligonychus Berlese, 1886: 24.

Paratetranychus Zacher, 1913: 39.

Type species: Heteronychus brevipodus Targioni Tozzetti, 1878, by original designation.

Female opisthosomal striae transverse on anterior portion of dorsocentral area and various in pattern on posterior portion. One pair of para-anal setae. Empodium claw-like, with pairs of proximoventral setae. Duplex setae on tarsus I distal and adjacent.

Fifteen species now known from Japan are referred to three species groups.

Key to the Species Groups of Oligonychus in Japan

1. Tibia I with 6-7 tactile setae; aedeagus curved ventrad

Tibia I with 9 tactile setae; aedeagus curved dorsad …..pratensis species group

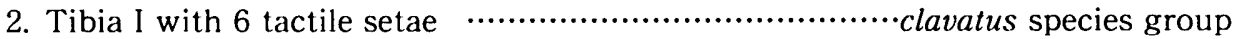

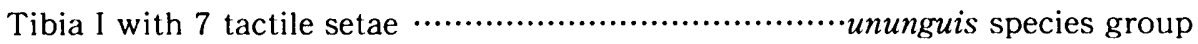

\section{clavatus species group}

Exemplar spccies: Paratetranychus clavatus Ehara, 1959

Tibia I with 6 tactile setae. Aedeagus downcurved posteriorly. Female reddish brown in color.

Key to the Species of the clavatus Species Group in Japan (Females)

1. Dorsal idiosomal setae set on tubercles, longer than intervals between their bases .pustulosus 
Dorsal idiosomal setae not set on tubercles, mostly shorter than intervals

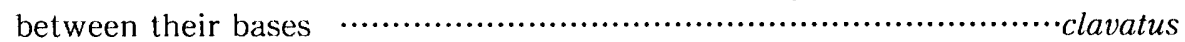

\section{Oligonychus clavatus (Ehara, 1959)}

(Fig. 131)

Paratetranychus clavatus Ehara, 1959a: 97, figs 1-13. [Type loc.: Hoshida, Katano, Osaka Pref.; type host: Pinus densiflora or P. thunbergii]

Oligonychus clavatus: Ehara 1962b: 157; Wang 1981: 93, fig. 80; Ma et al. 1984: 146, fig. 8 (60); Lee et al. 1989: 16, fig. 2.

The female is easily recognized by having the dorsal idiosomal setae shorter than the intervals between their bases. Seta L4 is often the longest among them.

Hosts. In Japan: Pinus densiflora, P. thunbergii.

Distribution. Honshu, Kyushu; Korea, China.

53. Oligonychus pustulosus Ehara, 1962

(Figs 122, 123, 132)

Oligonychus pustulosus Ehara, 1962b: 158, figs 1-7; Wang 1981: 100, fig. 87; Lee et al. 1989: 18, fig. 4; Ehara and Gotoh 1993b: 90, fig. 48. [Type loc.: Sapporo, Hokkaido; type host: Cryptomeria japonica]

This species is distinctive in that the dorsal idiosomal setae are set on tubercles and are much longer than the intervals between their bases. The pregenital setae are often much stouter than the other ventral idiosomal setae (Ehara 1964).

Host. Cryptomeria japonica.

Distribution. Hokkaido, Honshu, Kyushu; Korea, China.

ununguis species group

Ununguis Group Pritchard and Baker, 1955: 278 (in part).

Exemplar species: Tetranychus ununguis Jacobi, 1905.

Tibia I with 7 tactile setae. Aedeagus downcurved posteriorly. Female reddish brown or dark red.

Key to the Species of the ununguis Species Group in Japan (Females)

1. Dorsocentral opisthosomal setae shorter than distances between their bases $\cdots 2$ Dorsocentral opisthosomal setae about as long as, or longer than, distances between their bases …....................................................................

2. Dorsal idiosomal setae similar in length ................................karamatus Setae P1 and P2 (and seta H) longer than the other dorsal idiosomal setae ...... 
hondoensis

3. Dorsocentral opisthosomal setae noticeably longer than distances to bases of

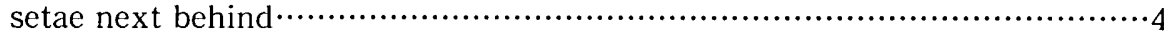

Dorsocentral opisthosomal setae approximately as long as distances to bases of

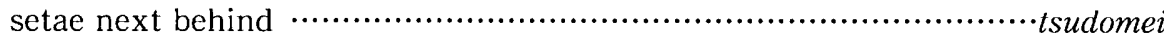

4. Seta L4 subequal in length to $\mathrm{C} 4$

Seta L4 much shorter than C4 …................................................... ilicis

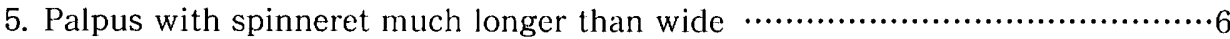

Palpus with spinneret about as long as wide …......................................

6. Tibiae I and II each with 2 tactile setae ventrad of duplex setae …........perdilus

Tibiae I and II each with 1 tactile seta ventrad of duplex setae $\cdots \cdots \cdots \cdot \cdots \cdot \cdots$....unguis

7. Tarsus II with 2 tactile setae and 1 solenidion proximal to duplex setae $\cdots$ gotohi

Tarsus II with 3 tactile setae and 1 solonidion proximal to duplex setae …......

coffeae

54. Oligonychus karamatus (Ehara, 1956)

(Fig. 133)

Paratetranychus karamatus Ehara, 1956a: 247, figs 5-10; Reck 1959: 68. [Type loc:

Nanaé, in the vicinity of Hakodate, Hokkaido; type host: larch (Larix leptolepis]

Oligonychus (Oligonychus) karamatus: Wainstein 1960: 207, figs 252, 253.

Oligonychus karamatus: Ehara 1962b: 161, figs 12-15; Mitrofanov 1967: 113, figs 3 (in

part), 13, 14; Ehara and Gotoh 1993b: 92, fig. 49.

Oligonychus laricis (nec Reeves): Boczek 1964: 368, fig. 8.

The female is distinctive in that the dorsal idiosomal setae are more or less similar in length to each other and generally shorter than the distances between their bases.

Host. In Japan: larch.

Distribution. Hokkaido, Honshu; Korea, China, Russia, Europe.

55. Oligonychus hondoensis (Ehara, 1954)

(Figs 124, 134)

Paratetranychus hondoensis Ehara, 1954: 102, figs 1-5; Reck 1959: 67. [Type loc: Shibusawa, Kanagawa Pref.; type host.: Cryptomeria japonica]

Oligonychus hondoensis: Pritchard and Baker 1955: 284; Ehara 1962b: 164, figs 16-21;

Ehara 1966b: 13; Wang 1981: 90, figs 77, 78; Ma et al. 1984: 148, fig. 8 (63); Lee et al. 1989: 17, fig. 3; Ehara and Gotoh 1993b: 94, fig. 50; Baker and Tuttle 1994: 255, fig. 175.

Oligonychus (Oligonychus) hondoensis: Wainstein 1960: 207; Jeppson et al. 1975: 195, fig. 35 .

Oligonychus weidhaasi Reeves, 1963: 58, figs 146-153.

The female is distinctive in that most of the dorsal idiosomal setae are much shorter than the distances between their bases, and setae P1, P2, and $\mathrm{H}$ are longer 

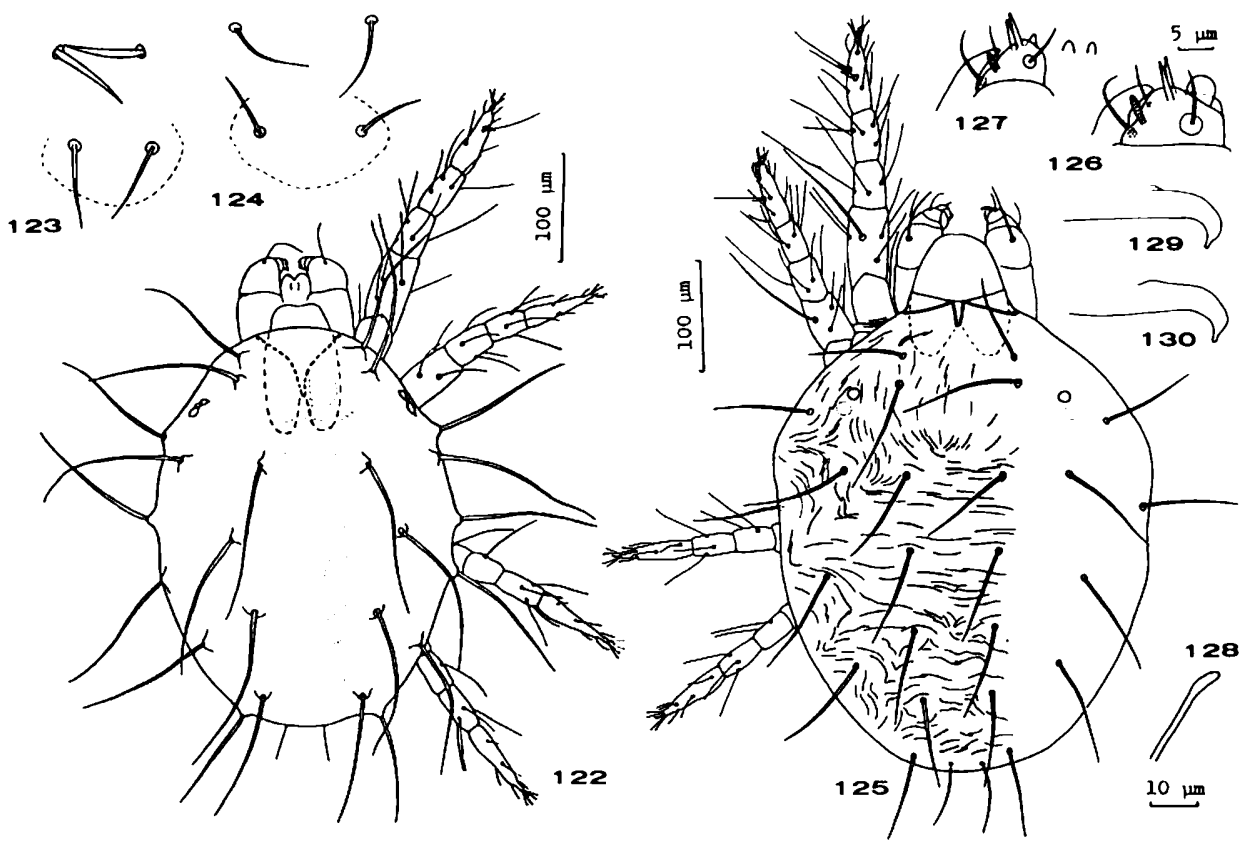

Figs 122, 123. Oligonychus pustulosus ( + ). 122, dorsum; 123, pregenital and first genital setae. Fig. 124. Oligonychus hondoensis ( + ), pregenital and first genital setae (magnification the same as in Fig. 123). Figs 125-130. Oligonychus coffeae. 125, dorsum ( + ); 126, distal segment of palpus ( + ); 127 , ditto $\left(\sigma^{7}\right)$, showing variation of spinneret; 128 , peritreme ( + ); 129,130 , aedeagus (126, 127, 129, 130 all at same magnification).

than the other dorsal idiosomals.

Host. Japanese cedar (Cryptomeria japonica).

Distribution. Hokkaido, Honshu, Shikoku, Kyushu, Okinawa Island; Korea, China, U.S.A., Hawaii, New Zealand.

\section{Oligonychus tsudomei Ehara, 1966}

(Fig. 135)

Oligonychus tsudomei Ehara, 1966b: 11, figs 14-21. [Type loc.: Haneji, Okinawa Island; type host: Pinus luchensis]

The female may be separated from those of the other species by the dorsocentral opisthosomal setae being approximately as long as the distances between consecutive setae.

Host. Pinus luchensis.

Distribution. Okinawa Island. 


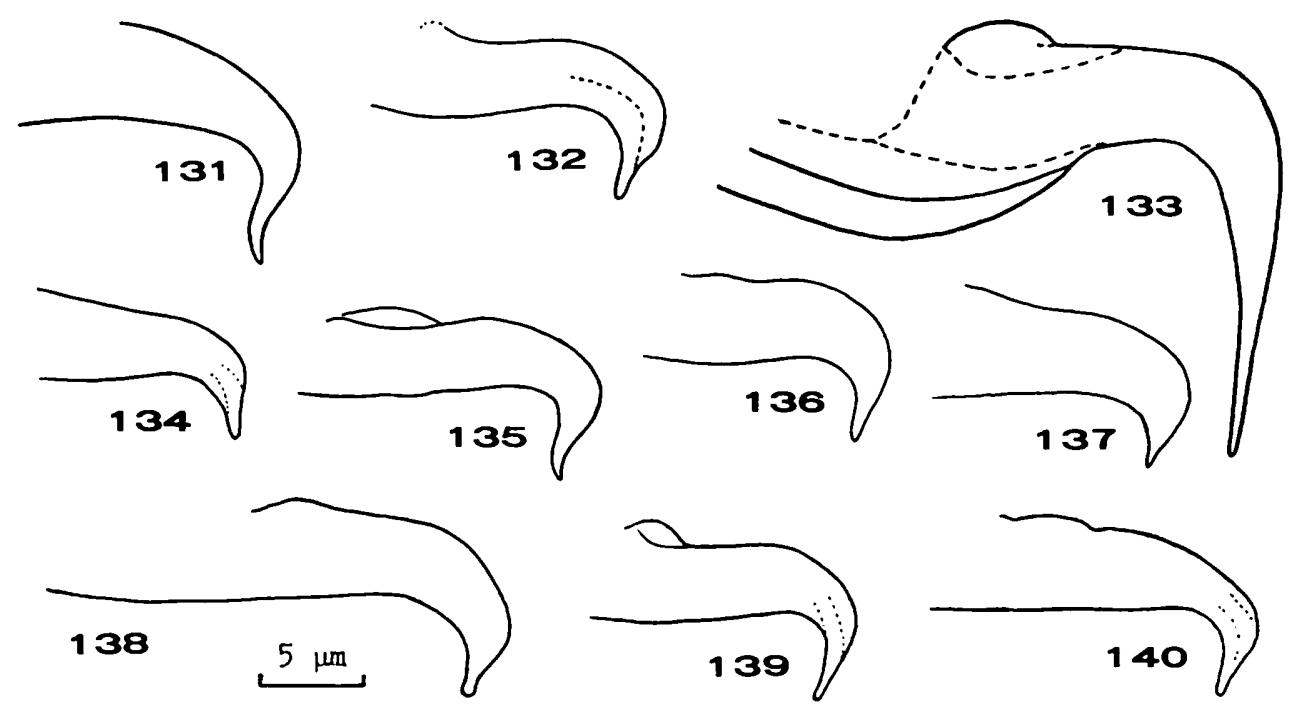

Figs 131-140. Aedeagi (all at same magnification). 131, Oligonychus clavatus; 132, O. pustulosus; 133, O. karamatus; 134, O. hondoensis; 135, O. tsudomei; 136, O. ilicis; 137 , O. gotohi sp. nov.; 138 , O. coffeae; 139, O. ununguis; 140, O. perditus.

57. Oligonychus ilicis (McGregor, 1917)

(Fig. 136)

Tetranychus ilicis McGregor, 1917: 686, pl. 106, figs 1-7. [Type loc.: Batesburg, South Carolina; type host: American holly]

Paratetranychus ilicis: McGregor 1919: 673, fig. 10, pl. 79, fig. 17; McGregor 1950: 340, pl. 38, fig. 14; Ehara 1960: 236, figs 16-27.

Oligonychus ilicis: Pritchard and Baker 1955: 305, figs 257-259; Ehara 1962b: 157;

Ehara 1963b: 230; Ehara and Gotoh 1993b: 96, fig. 51.

The female differs from those of the other members of the ununguis species group in having the dorsal idiosomal setae set on weak tubercles and in that seta L4 is much shorter than $\mathrm{C} 4$.

Hosts. In Japan: azalea (Rhododendron), tea, box tree (Buxus microphylla var. japonica, Eurya emarginata.

Distribution. Honshu, Shikoku, Kyushu, Okinawa Island; Korea, Europe, U.S.A., South America.

58. Oligonychus gotohi sp. nov.

(Japanese name: Bunaka-hadani)

(Figs 137, 141-151)

Oligonychus ununguis (nec Jacobi): Ehara 1962: 168 (in part); Ehara and Gotoh 
1993b: 98 (in part), fig. 52, B-E.

Female. Body, including rostrum, 480 long, 309 wide, red in color. Dorsal setae of idiosoma slender, pubescent, longer than distances between consecutive setae; lengths of setae $(\mathrm{n}=10)$ : P1 80.0 1.5 , P2 108.2 \pm 1.5, P3 90.1 $\pm 1.2, \mathrm{H} 93.2 \pm 1.6, \mathrm{C} 1$

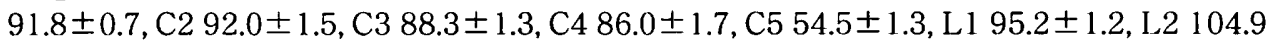
\pm 1.1 , L3 99.3 \pm 1.6, L4 76.1 \pm 1.5 . Opisthosoma with transverse striae on dorsocentral region. Peritremes dilated at distal end. Genital flap with transverse striae; area immediately anterior to flap with longitudinal striae. Palpus with spinneret approximately as long as wide; dorsal sensillum fusiform, tiny. Numbers of setae and solenidia (in parentheses) on leg segments: femora 8-6-2-1, genua 5-5-2-2, tibiae $7(1)-5-5-5$, tarsi 11(1) +2 dupl.-11(1) +1 dupl.-7(rarely 8)(1)-7(1). Tarsus I with 3 tactile setae and 1 solenidion proximal to duplex setae; tarsus II with 2 tactile setae and 1 solenidion proximal to duplex setae, and 1 tactile seta near duplex setae. Empodial claws I and II each with 5-6 pairs of proximoventral hairs; empodial claws III and IV each with 6 pairs of proximoventral hairs.

Male. Body, including rostrum, 361 long, 165 wide. Lengths of setae $(n=10): P 1$

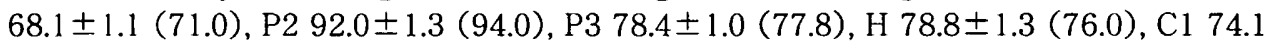

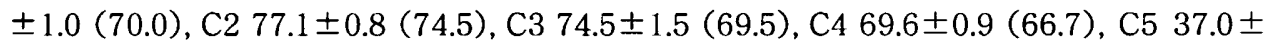

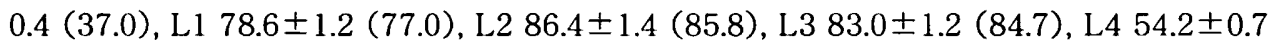
(54.4). Aedeagus with shaft bent ventrad at right angle to its axis, to form abruptly tapering distal portion with slender truncate tip. Palpus with spinneret much longer than broad, subeqaul in length to dorsal sensillum. Numbers of setae and solenidia (in parentheses) on podomeres: femora 8-6-2-1, genua 5-5-2-2, tibiae 7(4)-5-5-5, tarsi $11(3)+2$ dupl.-11(1) +1 dupl.-7(1)-7(1). Tarsus I with 3 tactile setae and 3 solenidia proximal to duplex setae; tarsus II with 2 tactile setae and 1 solenidion proximal to duplex setae, and 1 tactile seta near duplex setae. Empodia with 4-5 pairs of proximoventral hairs.

Type series. Holotype: $\sigma$. Tomiura, Chiba Pref., 13-VIII-1997 (T. Gotoh), on Pasania edulis. Paratypes: $6 \sigma^{\pi} \sigma^{\pi}$ and 10 우우, with the above data; $4 \sigma^{\pi}$ and 12 우우, Ohwashi, Tsukuba, Ibaraki Pref., 2-VI-1997 (T. Gotoh), on Pasania edulis.

In addition to Japanese specimens including the type series, a few Chinese specimens from chestnut (2 $\sigma^{7} \sigma^{7}$ and 2 우우, Shan xi sheng, 17-VII-1975, N. Shinkaji) were examined.

Hosts. Pasania edulis, chestnut, Quercus dentata, Q. serrata, Q. mongolica var. grosseserrata.

Distribution. Hokkaido, Honshu, Shikoku, Kyushu; China.

Remarks. Oligonychus gotohi closely resembles $O$. coffeae (see below) in the shape of the aedeagus and female spinneret, but is distinguished by the chaetotaxy of tarsi II to IV. Moreover, the new species is similar to O. buschi Reck, 1956 in the chactotaxy of tarsi I and II, but differs in having the female palpus about as long as wide, as opposed to the palpus being much longer than wide in O. buschi (Reck 1956; Bagdasarian 1957).

This species lives on fagaceous trees. It has so far been misidentified with Oligonychus ununguis from conifers, but differs from the latter in the shape of the female spinneret and the chaetotaxy of the leg tarsi. In addition, the number of proximal tactile setae on tarsus I may vary: The author has examined a few female specimens that bear 4 tactile setac and 1 solenidion on one leg and 3 tactile setae and 


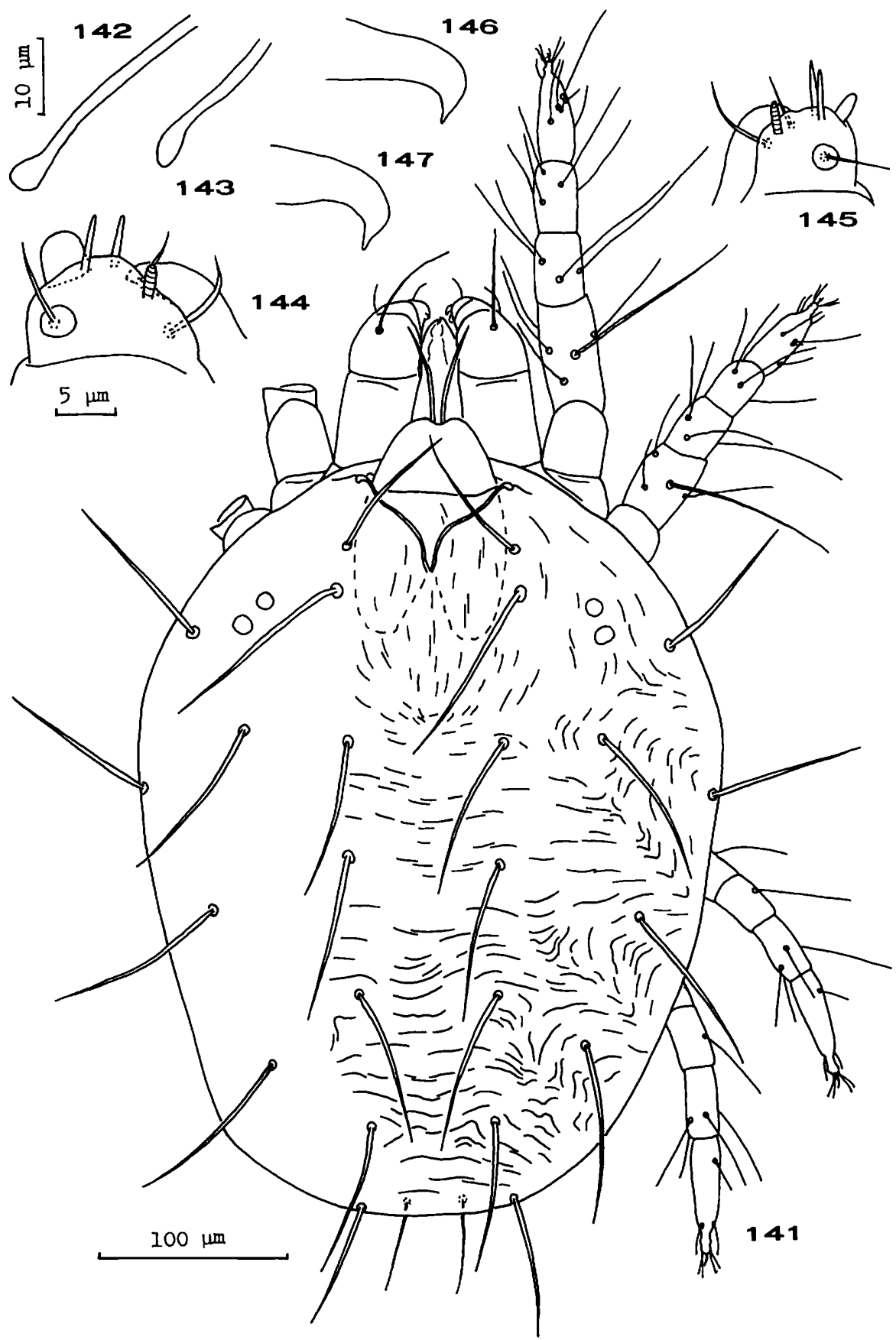

Figs 141-147. Oligonychus gotohi sp. nov. 141, dorsum ( + ); 142, 143, peritreme ( o , the same magnification); 144, distal segment of palpus ( + ); 145, ditto ( $\left.\sigma^{7}\right) ; 146,147$, aedeagus (146, holotype; 144-147 all at same magnification). 


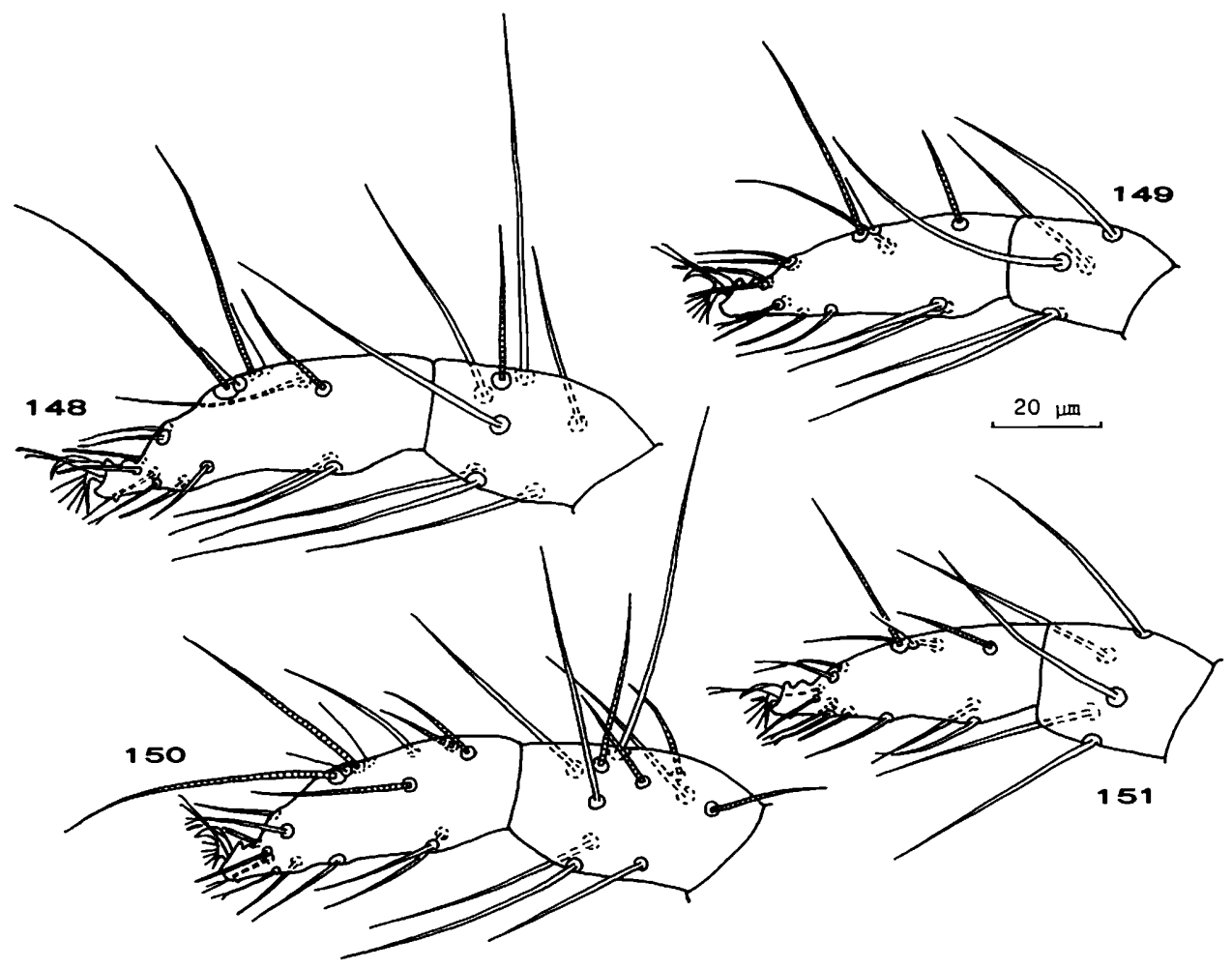

Figs 148-151. Oligonychus gotohi sp. nov. 148, tarsus and tibia I ( + ); 149, tarsus and tibia II ( 9 ); 150, tarsus and tibia I $\left(\sigma^{7}\right) ; 151$, tarsus and tibia II $\left(\sigma^{7}\right)$.

1 solenidion proximal to the duplex setae on the other leg.

Etymology. This new species is named in honor of Dr. T. Gotoh, Ibaraki University.

\section{Oligonychus coffeae (Nietner, 1861)}

(Figs 125-130, 138)

Acarus coffeae Nictner, 1861: 31. [Type loc:: Ceylon; type host: coffee trees]

Oligonychus coffeae: Pritchard and Baker 1955: 315, figs 268, 269; Ehara 1969c: 92,

figs 29-37; Meyer 1974: 251, figs 1015-1019; Ehara and Wongsiri 1975: 177, figs

94-96; Wang 1981: 102, fig. 90; Ehara and Tho 1988: 12; Baker and Tuttle 1994:

248, fig. 169 (c, f, g: copies of figures from Ehara 1969c); Ehara et al. 1997: 25, figs $1-4$.

Oligonychus (Oligonychus) coffeae: Lo and Ho 1989: 61, figs 1A, 7D.

The female is dark red. The spinneret on the female palpus is about as long as wide. The male spinneret varies: longer than wide or as long as wide. Chaetotaxic 
formula of legs: female, femora 8-6-2-1, genua 5-5-2-2, tibiae 7(1)-5-5-5, tarsi 11(1) + 2 dupl.-12(1) + 1 dupl.-8(1)-8(1); male, femora 8-6-2-1, genua 5-5-2-2, tibiae 7(4)-5-55 , tarsi $11(3)+2$ dupl. $-12(1)+1$ dupl.-8(1)-8(1).

This species is discriminated from the closely related species $O$. mangiferus (Rahman and Sapra, 1940) in the leg chaetotaxy and the shape of the aedeagus.

Collection data. Seven $\sigma^{\top} \sigma^{\pi}$ and 17 우 ㅇ. Uragami, Naze, Amami-öshima Island, 16-IV-1997 (T. Yamaguchi), on mango; $3 \delta^{\pi} \sigma^{\pi}$ and 5 우우, Onotsu, Kikai I., 16-III-1998 (T. Yamaguchi), on mango; 13 우우, Isen, Tokunoshima I., 4-III-1998 (T.Yamaguchi), on mango; $19 \sigma^{\pi} \sigma^{\top}$ and 25 우 오. Shuri-sakiyama-cho, Naha, Okinawa I., 14-V-1996 (M. Nagamine), on mango; $8 \sigma^{7} \sigma^{7}$ and 15 우우, Arashiyama, Nago, Okinawa I., 1-V-1997 (Y. Sato), on tea; $5 \sigma^{\top}$ and 13 우, Iriomote I., 10-VII-1997(H. Soemori), on mango.

Hosts. In Japan: mango, tea.

Distribution. Amami-ōshima Island, Kikai I., Tokunoshima I., Okinawa I., Iriomote I.; China, Hainan Island, Taiwan, Thailand, Malaysia, Philippines, Indonesia, Bangladesh, India, Sri Lanka, Transcaucasus, Mauritius, Réunion, Madagascar, Africa, U.S.A. (Florida), Central and South America, Australia, Tasmania, Hawaii, etc.

60. Oligonychus perditus Pritchard and Baker, 1955

(Figs 140,152,153)

Oligonychus perditus Pritchard and Baker, 1955: 316, figs 270-273; Ehara 1962b: 165, figs 22-29; Ehara 1963b: 230, fig. 11; Wang 1981: 101, figs 88, 89; Ma et al. 1984: 147, fig. 8 (62). [Type loc.: Japan, at Seattle, Washington quarantine; type host: juniper]

Oligonychus (Oligonychus) perditus: Tseng 1990: 122, figs 329-337.

Oligonychus perditus is closely allied to O. ununguis, but differs in having two tactile setae ventrad of the duplex setae on tarsi I and II of both sexes, and in lacking an unpaired ventral eupathidium slightly distal to the level of the duplex setae on these segments.

Host. In Japan: Juniperus.

Distribution. Hokkaido, Honshu; Korea, China, Taiwan, Holland.

61. Oligonychus ununguis (Jacobi, 1905)

(Figs 139, 154, 155)

Tetranychus ununguis Jacobi, 1905: 239. [Type loc:: Dahlem, Germany; type host: spruce]

Paratetranychus ununguis: Zacher 1913: 39.

Oligonychus ununguis: Hirst 1920: 59, figs 1k, 5d, 5h; Pritchard and Baker 1955: 319, figs 274-277; Ehara 1962b: 168 (in part), figs 30-36; Ehara 1966a: 142, figs 49-51; Wang 1981: 105 (in part), fig. 92; Ma et al. 1984: 152, fig. 8 (67) (copies of figures from Ehara 1962b); Ehara and Gotoh 1993b: 98 (in part), fig. 52.

Paratetranychus inouei Ehara, 1954: 104, figs 6-10.

This species can be separated from Oligonychus perditus by the single tactile seta 

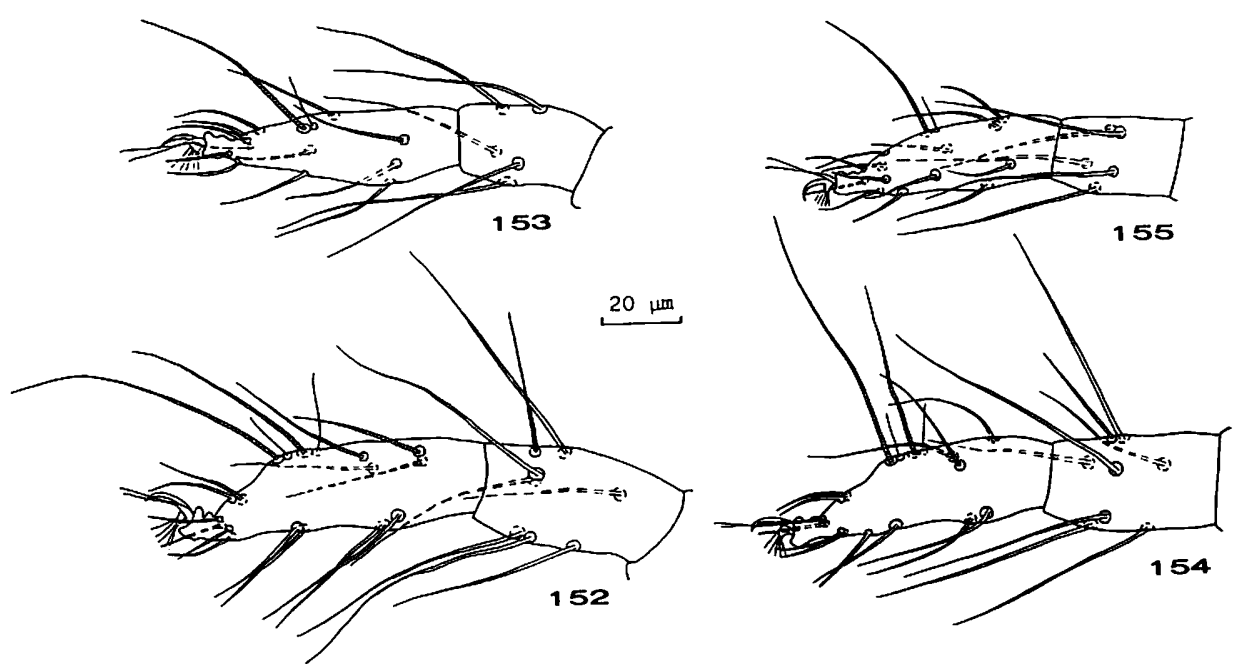

Figs 152, 153. Oligonychus perditus (ㅇ) ). 152, tarsus and tibia I; 153, tarsus and tibia II. Figs 154, 155, Oligonychus ununguis ( ㅇ ). 154, tarsus and tibia I; 155, tarsus and tibia II.

ventral to the duplex setae on tarsi I and II, and by having one ventral eupathidium slightly distal to the level of the duplex setae on these podomeres.

Hosts. In Japan: Pinus thunbergii, P. densiflora, Chamaecyparis obtusa, Picea jezoensis, $P$. jezoensis var. hondoensis, Abies sachalinensis, $A$. firma.

Distribution. Hokkaido, Honshu, Shikoku, Kyushu; Korea, China, Taiwan, Kazakhstan, Georgia, U.K., Europe, South Africa, North and South America, Cuba, Hawaii, Australia, New Zealand.

\section{pratensis species group}

Pratensis Group Pritchard and Baker, 1955: 343.

Pritchardi Group Pritchard and Baker, 1955: 362.

McGregori Group Pritchard and Baker, 1955: 358.

Exemplar species: Tetranychus pratensis Banks, 1912

Tibia I with 9 tactile setae. Aedeagus upturned posteriorly. Female pale greenish yellow or red.

Key to the Species of the pratensis Species Group in Japan

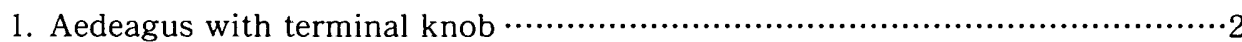

Aedeagus without terminal knob …..........................................orthius

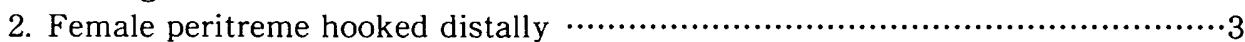

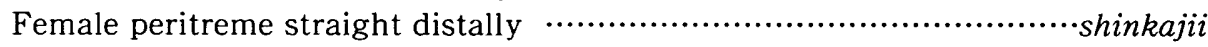


3. Terminal knob of aedeagus with posterior projection very small $\cdots \cdots \cdots \cdots \cdots \cdots \cdots$ Terminal knob of aedeagus with posterior projection very long, slender …......

biharensis

4. Terminal knob of aedeagus forming strong angle with axis of shaft ….uruma Terminal knob of aedeagus tiny, forming weak angle with axis of shaft

. formosanus

62. Oligonychus orthius Rimando, 1962

(Figs 156-158, 160)

Oligonychus orthius Rimando, 1962: 22, fig. 11 (in part); Ehara 1966b: 13, figs 22-30; Ehara 1969b: 21, figs 1-3, 13. [Type loc.: Victorias, Negros Occidental, Philippines; type host: Saccharum officinarum ]

Oligonychus (Reckiella) orthius: Lo and Ho 1989: 68, 7H: Tseng 1990: 132, figs 364-371.

The female is straw-colored and its peritreme is more or less bent at the distal end, but not U-shaped. The aedeagus is distinctive in having the upturned distal portion slender and sigmoid.

Hosts. In Japan: sugar cane, para grass.

Distribution. Okinawa Island; Korea, Taiwan, Thailand, Philippines.

63. Oligonychus shinkajii Ehara, 1963

(Figs 159, 161)

Oligonychus shinkajii Ehara, 1963b: 228, figs 1-6; Ehara 1969b: 22, figs 7-11, 14; Wang 1981: 98, fig. 85; Ma et al. 1984: 145, fig. 8 (59) (copies of figures from Ehara 1963b); Ehara and Shinkaji 1993: 100, fig. 53. [Type loc.: Hiratsuka, Kanagawa Pref.; type host: corn]

Oligonychus (Reckiella) shinkajii: Lo and Ho 1989: 69, figs 1E, F, 7J; Tseng 1990: 133, figs 372-385.

Oligonychus trachycarpus Lo, 1969: 67, fig. 31.

This species is distinctive in that the female peritreme is nearly straight distally, the terminal knob of the aedeagus is moderate in size, and the axis of the knob is parallel to the axis of the shaft. The female is pale grecnish ycllow.

Hosts. In Japan: sugar cane, rice, corn, and gramincous wild plants.

Distribution. Honshu, Kyushu, Tanegashima Island, Amami-ōshima I., Okinawa I.; Korea, China, Taiwan.

64. Oligonychus biharensis (Hirst, 1925)

(Fig. 163)

Paratetranychus biharensis Hirst, 1925: 69, fig. 15. [Type loc.: Pusa, India; type host: rose] 


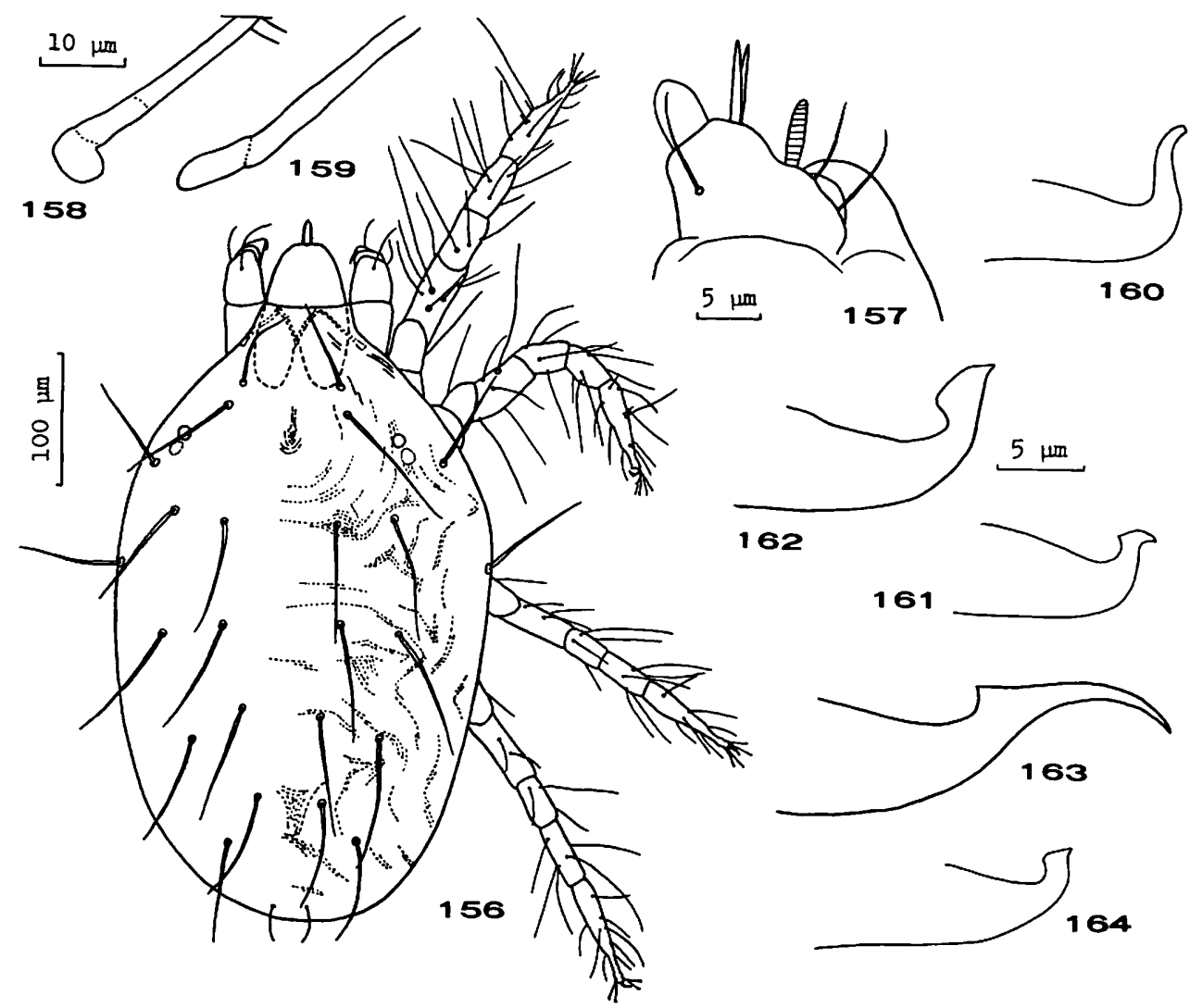

Figs 156-158. Oligonychus orlhius (우). 156, dorsum; 157, distal segment of palpus; 158, peritreme. Fig. 159. Oligonychus shinkajii (우), peritreme (magnification the same as in Fig. 158). Figs 160-164. Aedeagi (all at same magnification). 160, Oligonychus orthius; 161, O. shinkajii; 162 , O. uruma; 163, O. biharensis; 164, O. formosanus.

Oligonychus biharensis: Pritchard and Baker 1955: 364, figs 316-318; Ehara 1966b: 17, figs 40-47; Ehara 1969c: 95, fig. 41; Ehara and Wongsiri 1975: 177, fig. 97; Wang 1981: 95, fig. 83; Ehara and Tho 1988: 17, fig. 68; Gotoh et al. 1996: 91.

The female is dark red. The aedeagus is distinct in having the terminal knob convex dorsally, with a very long, downward-bending posterior projection.

Collection data. Ten 우우, Nagamine, Kikai Island, 16-III-1998 (T. Yamaguchi), on mango; $2 \sigma^{\top} \sigma^{\top}$ and 11 우우, Amagi, Tokunoshima I., 4-III-1998 (T. Yamaguchi), on mango; $3 \delta^{7} \sigma^{7}$ and 7 우 ㅇ. Shimajiri, Hirara, Miyako I., 5-VI-1997 (C. Shinjo), on mango; $3 \sigma^{7} \sigma^{7}$ and 7 우, 24-VI-1997, other data the same as for the preceding.

Hosts. In Japan: mango, Diospyros maritima, Pueraria montana.

Distribution. Kikai Island, Tokunoshima I., Okinawa I., Miyako I.; China, Hainan Island, Taiwan, Thailand, Malaysia, Philippines, Bangladesh, India, South Africa, Mauritius, Mexico, Antigua, South America, Hawaii, New Caledonia, Australia, etc. 
65. Oligonychus uruma Ehara, 1966

(Fig. 162)

Oligonychus uruma Ehara, 1966b: 15, figs 31-39. [Type loc.: Tomigusuku, Okinawa Island]

Oligonychus (Neonychus) uruma: Lo and Ho 1989: 74, figs 1I, J, 6, 7K.

Oligonychus (Pritchardinychus) uruma: Tseng 1990: 128, figs 343-352.

The female is pale yellowish and its peritreme is hooked distally. The aedeagus is distinctive in that the terminal knob forms a strong angle with the axis of the shaft and the dorsal margin of the knob is weakly angulate.

Hosts. In Japan: bamboo.

Distribution. Okinawa Island; Taiwan.

66. Oligonychus formosanus Lo, 1969

(Fig. 164)

Oligonychus formosanus Lo, 1969: 66, figs 24-30. ['Type loc.: Taipei, Taiwan; type host: sugar cane]

Oligonychus (Reckiella) formosanus: Lo and Ho 1989: 69, figs 4, 7 I.

Oligonychus rubicundus Ehara, 1971: 7, figs 1-8, 11-14; Wang 1981: 97, fig. 84.

The female is reddish in color. The peritreme of the female is hooked distally. The terminal knob of the aedeagus is very small, about one-fourth to one third as long as the dorsal margin of the shaft, and slightly wider than the stem of the knob, with the axis forming a weak angle with that of the shaft; the dorsal margin of the knob is barely undulate; the anterior projection of the knob is weakly developed, while the posterior projection is acute.

Hosts. In Japan: Miscanthus sinensis.

Distribution. Honshu; China, Taiwan.

\section{Genus Amphitetranychus Oudemans, 1931}

Amphitetranychus Oudemans, 1931b: 224; Geijskes 1939: 32; Navajas et al. 1997: 283. Viennensis Group Pritchard and Baker, 1955: 382.

Type species: Tetranychus (Epitetranychus) viennensis Zacher, 1915, by original designation.

Dorsocentral area of opisthosoma with transverse striae. One pair of para-anal setae. Peritreme anastomosing distally. Empodium usually consisting of 3 pairs of ventrally directed hairs, empodial spur minute or absent. Duplex setae on tarsus I widely separated. Tibia II with 6 tactile setae. Summer females red and overwintering females bright red. 
Key to the Species of Amphitetranychus in Japan (Males)

1. Aedeagus with distal, dorsally directed portion approximately as long as dorsal

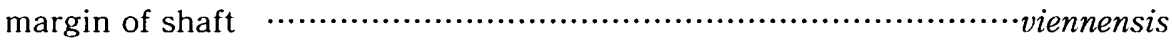

Aedeagus with distal, dorsally directed portion much shorter than dorsal margin

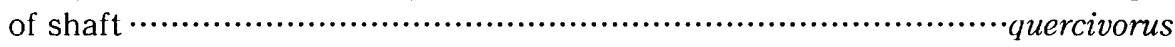

\section{Amphitetranychus viennensis (Zacher, 1915)}

(Figs 14, 165-168)

Tetranychus (Epitetranychus) viennensis Zacher, 1915: 186, figs 7-10; Zacher 1920: 1. [Type loc: Wien, Austria; hosts of syntypes: apple, pear, sour cherry, sweet cherry]

Tetranychus crataegi Hirst, 1920: 51, figs 1g, 3a, 4a.

Amphitetranychus viennensis: Oudemans 1931 b: 224; Geijskes 1939: 41, fig. 37; Ehara 1956a: 252, figs 16-19; Navajas et al. 1997: 288.

Tetranychus viennensis: Pritchard and Baker 1955: 384, figs 335, 336; Ehara 1964: 41 1; Ehara and Gotoh 1993b: 102, fig. 54.

Tetranychus (Amphitetranychus) viennensis: Wainstein 1960: 164, figs 189-193.

Tetranychus pacificus (nec McGregor): Nishio 1954: 31, figs.

This species may be recognized by the distal portion of the peritreme, which anastomoses to end in a mazy globe measuring $30-40 \mu \mathrm{m}$ in diameter in the female. The aedeagus turns up posteriorly to form a very slender distal portion that is approximately equal in length to the dorsal margin of the shaft and bears a very small proximal projection. The males are red in color as well as the summer females.

Hosts. In Japan: apple, pear, sweet cherry, sour cherry, Japanese apricot, peach.

Distribution. Hokkaido, Honshu, Shikoku, Kyushu; Korea, China, Taiwan, Iran, Central Asia, Armenia, Lebanon, Turkey, U.K., Europe.

68. Amphitetranychus quercivorus (Ehara and Gotoh, 1990)

(Figs 169-178)

Tetranychus quercivorus Ehara and Gotoh, 1990: 55, figs 1-10, 15-19; Ehara and Gotoh 1993b: 104, fig. 55. [Type loc.: Sapporo, Hokkaido; type host: Quercus mongolica var. grosseserrata]

Amphitetranychus quercivorus: Navajas et al. 1997: 288.

This species differs from $A$. viennensis in that the distal anastomosing portion of the peritreme is smaller, measuring $20-30 \mu \mathrm{m}$ in diameter in the female, and that the distal, dorsally directed portion of the aedeagus is much shorter than the dorsal margin of the shaft. Males of this species are pale greenish yellow, while those of $A$. viennensis are red like the summer females of both species.

Host. Quercus mongolica var. grosseserrata.

Distribution. Hokkaido, Honshu. 


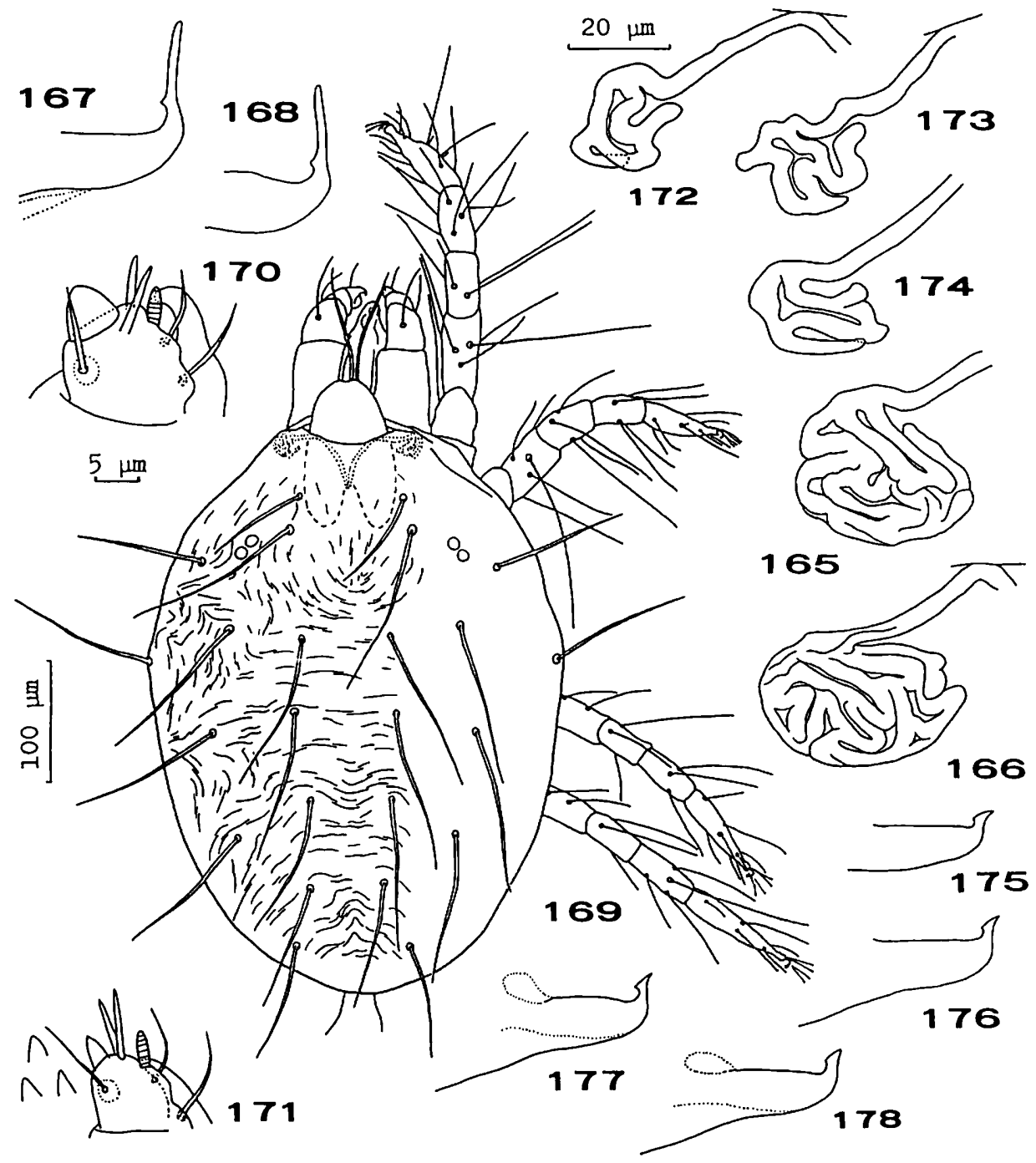

Figs 165-168. Amphitetranychus viennensis. 165, 166, peritreme ( \& ); 167, 168, aedeagus. Figs 169-178. Amphitetranychus quercivorus. 169, dorsum ( + ); 170, distal segment of palpus ( + ); 171 , ditto $\left(\sigma^{7}\right) ; 172-174$, peritremes ( 9 , magnification the same as in Figs 165,166$) ; 175-178$, aedeagi (magnification the same as in Figs 167, 168, 170, 171).

\section{Genus Tetranychus Dufour, 1832}

Tetranychus Dufour, 1832: 276.

Type species: Tetranychus lintearius Dufour, 1832, by original designation. Dorsocentral area of opisthosoma with striae entirely or mostly transverse. One pair 
of para-anal setae. Peritreme with distal portion hooked. Empodia usually consisting of 3 pairs of ventrally directed hairs, mediodorsal spur present or absent; male empodium I usually composed of pair of short, tridigitatc, claw-like divisions with or without mediodorsal spur. Duplex setae on tarsus I widely separated. Tibia II with 7 tactile setae. Aedeagus bent dorsad.

The genus Tetranychus was divided into three species groups by Baker and Tuttle (1994) on the basis of the dorsocentral striation pattern of the females: pacificus group, canadensis group, and urticae group. All known Japanese species of Tetranychus are referred to the urticae species group, which includes the species with the dorsal opisthosomal striae of the female forming a diamond-shaped pattern between the third and fourth pairs of dorsocentral setae.

\section{Key to the Species of Tetranychus in Japan}

1. Tarsus I of female with proximal pair of duplex setae distal to other proximal tactile setae

Tarsus I of female with proximal pair of duplex setae in line with most other

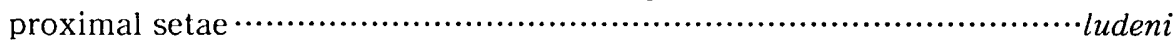

2. Female empodium with mediodorsal spur rather inconspicuous or absent; female spinneret approximately twice as long as wide …….....urticae complex $\cdots \cdots \cdot 3$

Female empodium with strong mediodorsal spur; female spinneret slightly

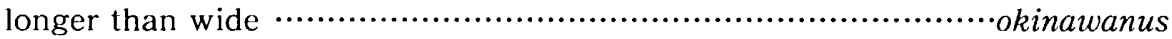

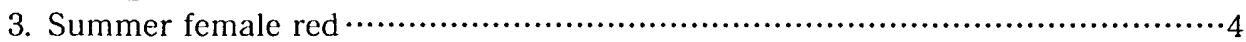

Summer female pale green to straw-colored; aedeagus with terminal knob 2.5-2.6 $\mu \mathrm{m}$ in diameter; diapausing female yellowish orange $\cdots \cdots \cdot$ urticae, green form

4. Aedeagus with distal termination more or less dilated to form definite terminal

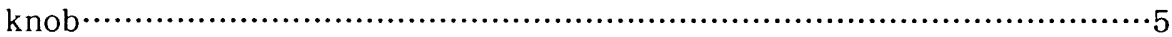

Aedeagus with distal termination scarcely dilated …...........................piercei

5. Terminal knob of aedeagus much shorter than dorsal margin of shaft $\cdots \cdots \cdots \cdots \cdots$

Terminal knob of aedeagus very long, approximately as long as dorsal margin of

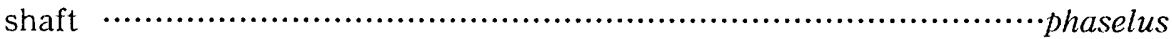

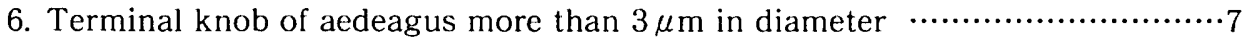

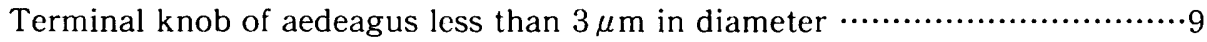

7. Terminal knob of aedeagus ca. $4 \mu \mathrm{m}$ in diameter …........................kanzawai

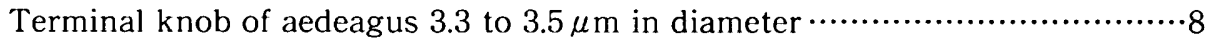

8. Terminal knob of aedeagus with dorsal margin nearly semicircular or inconspicuously angulate .....................................................parakanzawai

Terminal knob of aedeagus with dorsal margin conspicuously angulate; on conifer (Taxus) ..................................................................ezoensis

9. Terminal knob of aedeagus conspicuous (more than $2 \mu \mathrm{m}$ in diameter) $\cdots \cdots \cdot 10$

Terminal knob of aedeagus inconspicuous (ca. $1.5 \mu \mathrm{m}$ in diameter) $\cdots$ truncatus

10. Terminal knob of aedeagus $2.5-2.6 \mu \mathrm{m}$ in diameter; non-diapausing...............

urticae, red form

Terminal knob of aedeagus ca. $2.1 \mu \mathrm{m}$ in diameter; diapausing females present $\cdots$ pueraricola 
69. Tetranychus ludeni Zacher, 1913

(Figs $6-8,15,179,180,187$ )

Tetranychus ludeni Zacher, 1913: 40, fig. 3; Pritchard and Baker 1955: figs 355-358; Meyer 1974: 245, figs 1007, 1210-1212; Wang 1981: 112, fig. 99a; Ehara and Masaki 1989: 49, figs 1-13; Ehara and Masaki 1993: 106, fig. 56. [Type loc.: St. Cloud, near Paris, France; hosts of syntypes: Salvia splendens, Solanum melongena, Cucurbila sp.]

Tetranychus (Pseudonychus) ludeni: Wainstein 1960: 162.

Tetranychus desertorum (nec Banks): Ehara 1956b: 144, figs 22-30; Ehara 1960: 238;

Ehara 1962a: 106.

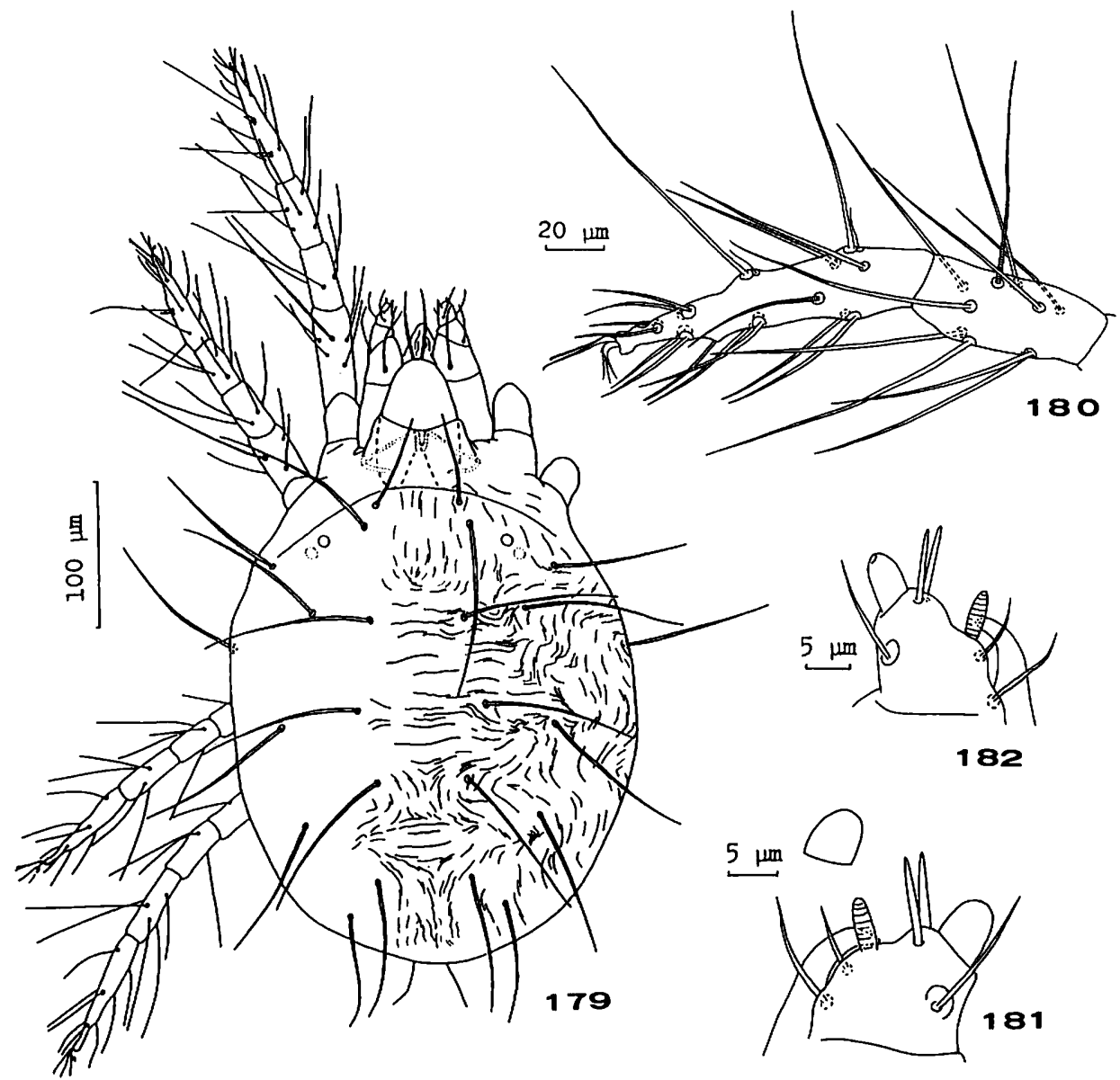

Fig. 179, 180. Tetranychus ludeni ( + ). 179, dorsum; 180, tarsus and tibia I. Fig. 181. Tetranychus okinawanus ( + ), distal segment of palpus. Fig. 182. Tetranychus pueraricola ( + ), distal segment of palpus. 


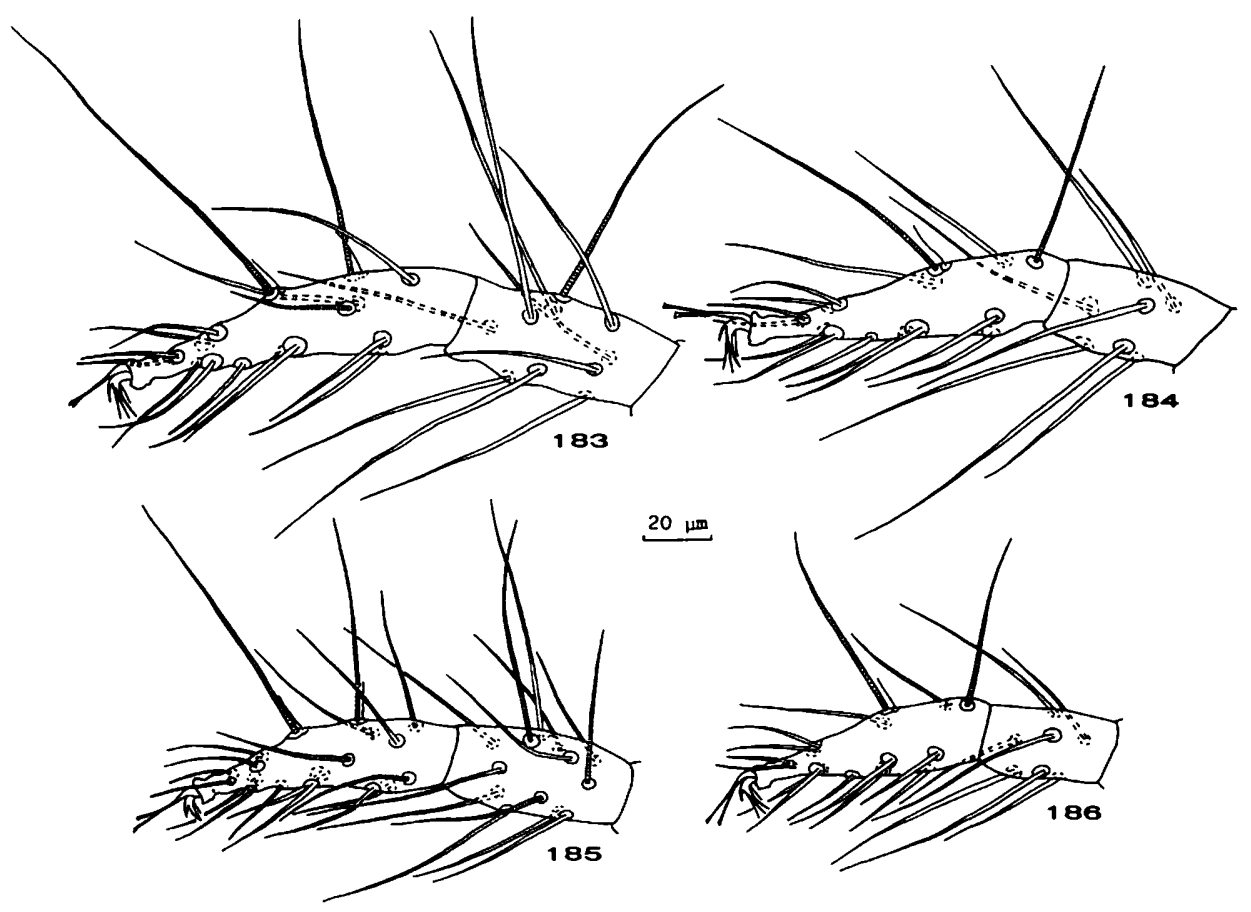

Figs 183-186. Tetranychus okinawanus. 183, tarsus and tibia I ( + ); 184, tarsus and tibia II ( + ); 185 , tarsus and tibia I $\left(\sigma^{7}\right) ; 186$, tarsus and tibia II $\left(\sigma^{7}\right)$.

This species is distinctive in that the proximal pair of duplex setae on tarsus I in the female are in line with most of the other proximal setae. The spinneret on the female palpus is about one and half times as long as wide. The upturned distal portion of the aedeagus recurves to end in a very small terminal knob which is pointed anteriorly and rounded posteriorly.

Hosts. In Japan: Phaseolus vulgaris, soybean, eggplant, cucumber, melon, Brassica campestris var. perviridis, potato, perilla, mulberry, marigold, Gerbera, Cardiospermum halicacabum, Cosmos, Bidens biternata, white clover, Solidago altissima.

Distribution. Hokkaido (in greenhouse), Honshu, Shikoku, Kyushu, Okinawa Island; China, Taiwan, Thailand, India, Europe, U.S.A., Mexico, Central and South America, Africa, Madagascar, Hawaii, Cook Is., Fiji, New Caledonia, Australia, Tasmania, New Zealand.

70. Tetranychus okinawanus Ehara, 1995

(Figs 181, 183-186, 188)

Tetranychus okinawanus Ehara, 1995: 229, figs 1-13. [Type loc.: Shuri, Naha, Okinawa Island; type host: Pueraria montana (misidentified as $P$. lobata in the original description)] 
Tetranychus okinawanus may be easily recognized by the slightly longer than broad female spinneret and the strong mediodorsal spur on the empodium. The terminal knob of the aedeagus is $3.5 \mu \mathrm{m}$ in diameter, much longer than the width of the neck, and approximately one half the length of the dorsal margin of the shaft; the axis of the knob is subparallel with the dorsal margin of the shaft; the anterior projection of the knob is broadly rounded, and the posterior projection is very small and acute.

IIosls. Pueraria montana, sweet potato, Solanum nigrum, Phaseolus vulgaris, Bidens pilosa var. minor, Sonchus.

Distribution. Okinawa Island, Oujima I., Ishigaki 1.

\section{Tetranychus phaselus Ehara, 1960}

(Fig. 189)

Tetranychus phaselus Ehara, 1960: 238, figs 28-39; Ehara 1969c: 97, figs 48, 49, 52-55,

63, 64; Wang 1981: 116, fig. 102; Ehara and Masaki 1993: 108, fig. 57. [Type loc:

Ninomiya, Kanagawa Pref.; type host: Phaseolus vulgaris]

This species has a distinctive aedeagus with a very long terminal knob (ca. 10 $\mu \mathrm{m})$.
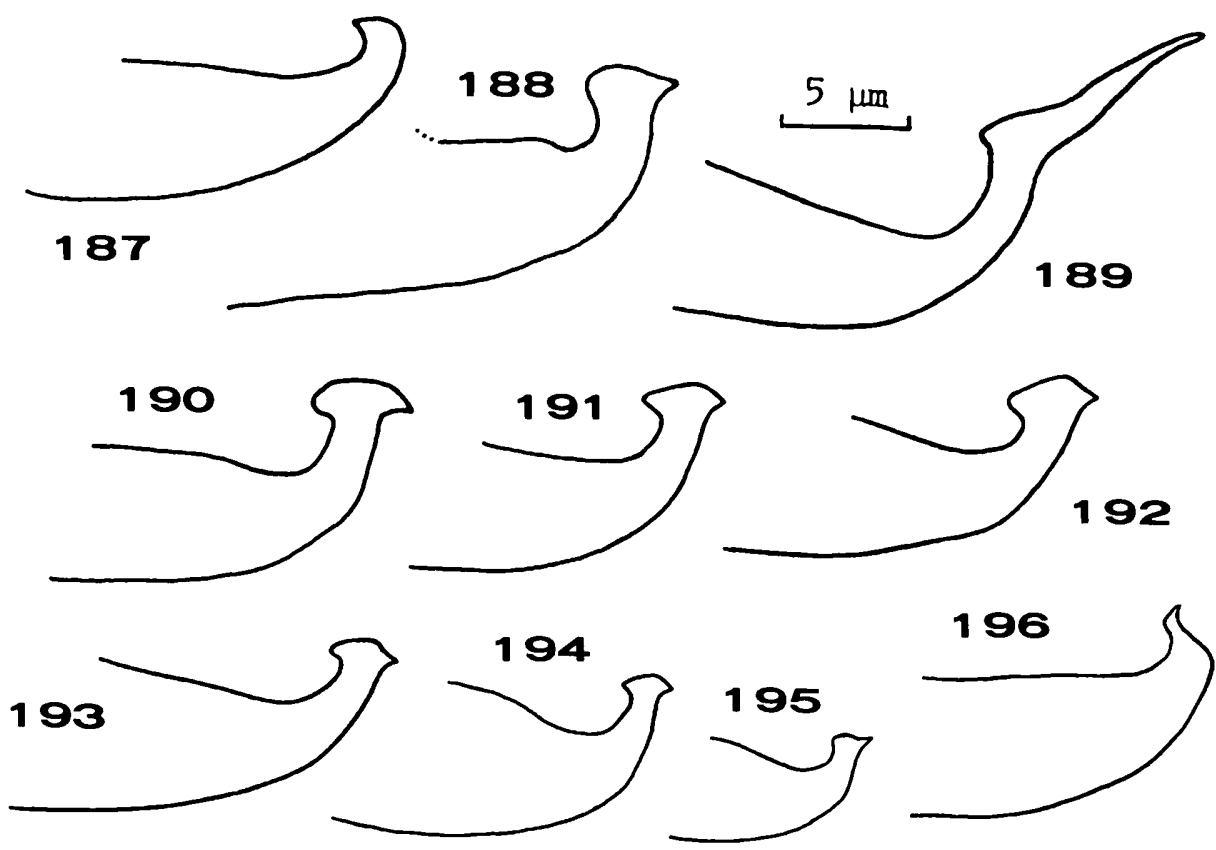

Figs 187-196. Aedeagi (all at same magnification). 187, Tetranychus ludeni; 188, T. okinawanus; 189, T. phaselus; 190, T. kanzawai; 191, T. parakanzawai sp. nov.; 192, T. ezoensis; 193, T. urticae; 194, T. pueraricola; 195, T. truncatus; 196, T. piercei. 
Hosts. In Japan: Phaseolus vulgaris, Boehmeria nivea, Fatoua villosa.

Distribution. Honshu, Kyushu; Korea, China, Taiwan.

72. Tetranychus kanzawai Kishida, 1927

(Fig. 190)

Tetranychus kanzawai Kishida, 1927: 105; Ehara 1956c: 504, figs 15-25; Ehara 1960: 240; Ehara 1963b: 230, figs 12-15; Ehara 1969c: 98, figs 65-67; Ehara and Tho 1988: 23, fig. 70; Ehara and Masaki 1989: 52, fig. 14; Ehara and Hamamura 1993: 110, fig. 58. [Type loc.: Yamanashi Pref.; type host: mulberry]

Tetranychus japonicus Hotta, 1928: 10.

The aedeagus is characterized by a large terminal knob which is about $4 \mu \mathrm{m}$ in diameter and with a nearly semicircular dorsal margin.

Hosts. In Japan: tea, pear, peach, apple, sweet cherry, citrus, persimmon, grape, mulberry, hops, eggplant, soybean, Phaseolus vulgaris, Colocasia esculenta, sweet potato, strawberry, corn, rice, cucurbitaceous plants, hydrangea, etc.

Distribution. Hokkaido, Honshu, Shikoku, Kyushu, Okinawa Island; Korea, China, Taiwan, Thailand, Malaysia, Philippines, Australia.

73. Tetranychus parakanzawai sp. nov.

(Japanese name: nise-kanzawa-hadani)

(Figs 191, 197-201)

Female. Body, including rostrum, 571 long, 373 wide, red in color. Dorsal idiosomal setae longer than intervals between their bases; lengths of setae $(n=10)$ :

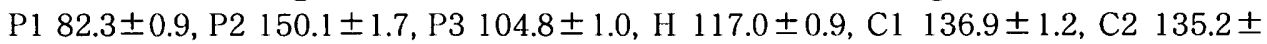

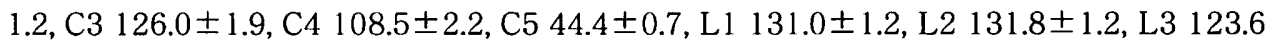
\pm 1.8, L4 93.9 \pm 0.9 . Striae of opisthosomal dorsum forming diamond pattern as usual; lobes of striae very variable in shape, generally rounded distally. Peritreme strongly hooked distally. Spinneret approximately twice as long as broad. Chaetotaxic formula of legs: femora 10-6-4-4, genua 5-5-4-4, tibiae 9(1)-7-6-7, tarsi 13(1)+2 dupl.-13(1) + 1 dupl.-9(1)-10(1). Tarsus I with 4 tactile setae proximal to proximal set of duplex setae, with 1 solenidion at level of posterior duplex setae; tarsus II with 3 tactile setae and 1 solenidion proximal to duplex setae, and 1 tactile seta near duplex setae. Empodium with mediodorsal spur minute or absent.

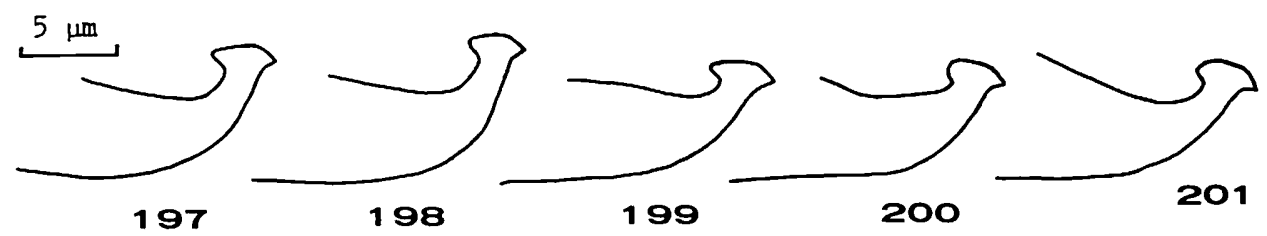

Figs 197-201. Tetranychus parakanzawai sp. nov., aedeagi (197, holotype). 
Male. Body, including rostrum, 449 long. Lengths of setae: P1 60.1 \pm 1.4 (58.0), P2

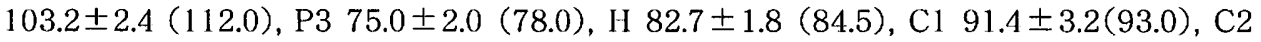

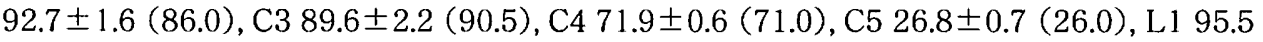

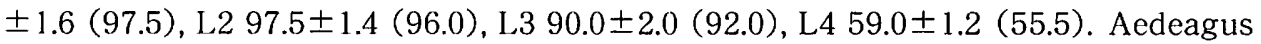
bent dorsad distally; terminal knob 3.3 long, much longer than width of neck, approximately $1 / 3$ to $1 / 2$ as long as dorsal margin of shaft, axis of knob subparallel with dorsal margin of shaft; anterior projection of knob rounded, posterior projection acute. Spinneret very slender. Chaetotaxic formula of legs: femora 10-6-4-4, genua 5-5-4-4, tibiae 9(4)-7-6-7, tarsi 13(3)+2 dupl.-13(1)+1 dupl.-9(1)-10(1). Tarsus I with 4 tactile setae and 2 solenidia proximal to proximal set of duplex setae, and 1 solenidion at level of proximal duplex set; tarsus II with 3 tactile setae and 1 solenidion proximal to duplex setae, and 1 tactile seta near duplex setae. Empodia I and II with strong mediodorsal spur; empodia III and IV with minute mediodorsal spur.

Type series. Holotype: $\sigma^{\top}$, Ami, Ibaraki Pref., 5-VI-1993 (T. Gotoh), on Puelaria lobata. Paratypes: $5 \sigma^{\top} \sigma$ and 10 우, with the above data.

Remarks. The aedeagus of this new species closely resembles that of Tetranychus kanzawai, but differs from the latter in that the terminal knob is around $3.3 \mu \mathrm{m}$ in length instead of $4 \mu \mathrm{m}$. This species has so far been referred to as the kudzu population of T.kanzawai, and female mites of the population were recently confirmed to be reproductively incompatible with males of the other populations of kanzawai (Gomi and Gotoh 1996).

Etymology. Referring to the morphological similarities between the new species and T. kanzawai.

\section{Tetranychus ezoensis Ehara, 1962}

(Fig. 192)

Tetranychus ezoensis Ehara, 1962b: 171, figs 37-42. [Type loc.: Sapporo; type host: Taxus cuspidata]

The aedeagus is distinctive in having its terminal knob $3.5 \mu \mathrm{m}$ in diameter and an obtusely angulate dorsal margin. The female is pale red.

Host. Taxus cuspidata.

Distribution. Hokkaido.

\section{Tetranychus urticae Koch, 1836}

(Fig. 193)

Tetranychus urticae Koch, 1836: 10; Geijskes 1939: 36, figs 25, 26; Boudreaux and Dosse 1963: 359; Ehara 1966a: 143, figs 47, 48; Tuttle and Baker 1968: 129; Dupont 1979: 297; Ehara and Shinkaji 1993: 112, fig. 59. [Type loc.: Regensburg, Germany; type host: nettle]

Tetranychus telarius (Linnaeus): Pritchard and Baker 1955: 432, figs 386-391, pl. 1; Ehara 1956a: 249, figs 11-15.

Tetranychus cinnabarinus (Boisduval): Boudreaux 1956: 46, figs 2, 4, 6, 9, 11, 12; 
Ehara 1956b: 146, figs 31-37; Ehara 1962a: 107.

The two-spotted spider mite, Tetranychus urticae, has been regarded as including a green form and red form (carmine form) by many authors, on the basis of Dupont's work (1979) on the incomplete reproductive isolation between the two forms.

Tetranychus urticae is distinguished from related species by the shape and size of the aedeagus: the terminal knob is about $2.5-2.6 \mu \mathrm{m}$ in diameter, approximately as long as $1 / 4$ the length of the dorsal margin of the shaft.

Hosts. Numerous plant species including fruit trees, vegetables, and ornamental plants and flowers.

Distribution. Hokkaido, Honshu, Shikoku, Kyushu, Okinawa Island; cosmopolitan.

76. Tetranychus pueraricola Ehara and Gotoh, 1996

(Figs 182, 194)

Tetranychus pueraricola Ehara and Gotoh, 1996: 21, figs 36-44, 48-51; Goloh et al. 1996: 91. [Type loc.: Hitachi-Ohta, Ibaraki Pref.; type host: Pueraria lobala]

The aedeagus differs from that of Tetranychus urticae in having the terminal knob smaller, about $2.1 \mu \mathrm{m}$ in diameter. The summer females are red, and the diapausing females are bright red.

Hosts. Pueraria lobata, P. montana.

Distribution. Honshu, Okinawa Island.

77. Tetranychus truncatus Ehara, 1956

(Fig. 195)

Tetranychus truncatus Ehara, 1956c: 507, figs 28-31; Rimando 1962: 31, fig. 12 (in part); Ehara 1963b: 231, figs 16-19; Ehara 1969c: 99, fig. 70; Ehara and Wongsiri 1975: 182, figs 117-119; Wang 1981: 118, fig. 99e, 101g, h, pl. I, fig. 6. [Type loc: Suginami, Tokyo; type host: mulberry]

The aedeagus is distinctive in having a tiny terminal knob (ca. $1.5 \mu \mathrm{m}$ in diameter) which is apparently truncate with a slight notch on the dorsal margin.

Hosts. In Japan: mulberry, beet, eggplant, melon.

Distribution. Honshu, Kyushu; Korea, China, Hainan Island, Taiwan, Thailand, Philippines, Indonesia, Mariana Islands.

78. Tetranychus piercei McGregor, 1950

(Fig. 196)

Tetranychus piercei McGregor, 1950: 299, fig. 7, pl. 6, fig. 13; Pritchard and Baker 1955: 431, fig. 385; Rimando 1962: 28, fig. 12 (in part); Ehara 1966b: 20, figs 50-52; Ehara 1969c: 100, figs 71, 72; Wang 1981: 117, figs 99d, 101e; Gotoh et al. 1996: 91. [Type loc.: Victorias Occ. Negros, Philippine Islands; type host: Clitoria 
ternatea]

The aedeagus is distinctive in that the terminal knob is diminutive and scarcely discernible, forming a definite angle with the axis of the shaft, and that the anterior angulation of the knob is inconspicuous and obtuse and the posterior projection is acute.

Collection data. Six $\sigma^{\nearrow} \sigma^{\nearrow}$ and 6 우우, Hachinohe, Aomori Pref., 16-IX-1996 (Y. Kimura), on Pharbitis nil; $8 \sigma^{\top} \sigma^{\top}$ and 6 우우, Taito, Wakayama Pref., 17-VII-1996 (M. Morishita), on Viola grypoceras.

Hosts. In Japan: sweet potato, a palm, Pueraria montana, Pharbitis nil, Viola grypoceras.

Distribution. Honshu, Okinawa Island; China, Hainan Island, Taiwan, Vietnam, Thailand, Malaysia, Philippines, Indonesia, Papua New Guinea, Surinam.

\section{Taxa Erroneously Assigned to Tetranychidae}

Genus Tacebia Yokoyama, 1929

Tacebia Kishida: Yokoyama, 1929: 536; Ehara 1956c: 504.

Type of genus: Tacebia parva Yokoyama, 1929, by monotypy.

Although Yokoyama (1929) did not give the description of the genus Tacebia, this genus was validated by his description of T. parva. Pritchard and Baker (1955) considered the genus Tacebia a junior synonym of Oligonychus. However, the present author is of the opinion that Tacebia is probably a senior synonym of the genus Agistemus Summers, 1960, belonging to the family Stigmaeidae. The reason is mentioned below.

Tacebia parva Yokoyama, 1929

Tacebia parva Kishida: Yokoyama, 1929: 536; Ehara 1956c: 504; Ehara 1977b: 247.

[Type loc.: Suginami (?), Tokyo; type host: mulberry]

Oligonychus parva: Pritchard and Baker 1955: 341.

Though Tacebia parva was credited to Kishida, no description by Kishida had been published. Therefore, T. parva was validated by Yokoyama (1929), who really published the description of this species for the first time.

The type series of T. parva was lost, unfortunately. According to Yokoyama's description, the females are bright red and their legs bear two strong claws. Judging from these characteristics, it is almost certain that $T$. parva does not belong to the Tetranychidae but to the genus Agistemus Summers, 1960 (Stigmaeidae), and it may probably be referred to either A. terminalis (Quayle, 1912) or A. exsertus González, 1963. These two stigmaeid species are common on a wide variety of plants in Honshu, and are found preying on eggs of spider mites, as well as other thing (Ehara 1977a). 


\section{Acknowledgements}

The author is very grateful to Dr. T. Gotoh for his kind and extensive help, particularly in furnishing some of the material for this work, and to Dr. U. Gerson for supplying him with Palestine articles. The author is also intebted to the following gentlemen for gifts of parts of the present material: K. Goka, J. Iwamoto, Y. Kunimoto, Y. Kunugi, M. Mochizuki, M. Nagamine, N. Shinkaji, T. Tsuchiya, T. Yamaguchi, and K. Yogi. Finally, he extends his thanks to anonymous reviewers who made valuable suggestions.

\section{References}

Alberti, G. and Storch, V. 1974. Über Bau und Funktion der Prosoma-Drüsen von Spinnmilben (Tetranychidae, Trombidiformes). Zeitschrift für Morphologie und Ökologie der Tiere 79: 133-153.

Bagdasarian, A. T. 1957. Fauna Armianskoi S.S.R. Tetranychid Mites (Superfamily Tetranychoidea). Akademija Nauk Armianskoi S.S.R., Zoologicheskii Institut, Erevan, Armenia, 163pp. [In Russian]

Baker, E. W. and Pritchard, A. E. 1953. A guide to the spider mites of cotton. Hilgardia 22: 203-234.

Baker, E. W. and Pritchard, A. E. 1960. The tetranychoid mites of Africa. Hilgardia 29: 455-574.

Baker, E. W. and Pritchard, A. E. 1962. Arañas rojas de America Central (Acarina: Tetranychidae). Revista de la Sociedad Mexicana de Historia Natural 23: 309-340, 8 pls.

Baker, E. W. and Tuttle, D. M. 1994. A Guide to the Spider Mites (Tetranychidae) of the United States. Indira Publishing llouse, West Bloomfield, Michigan, $347 \mathrm{pp}$.

Baker, E. W. and Wharton, G. W. 1952. An Introduction to Acarology. The Macmillan Company, New York, xiii +465 pp. +1 pl.

Banks, N. 1900. The red spiders of the United States (Tetranychus and Stigmaeus). U. S. Department of Agriclture, Division of Entomology, Technical Series 8: 65-77.

Banks, N. 1912. New American mites. Proceedings of the Entomological Society of Washington 14: $96-99$.

Banks, N. 1917. New mites, mostly economic (Arach., Acar.). Entomological News 28: 193-199, pls. 14-15.

Berlese, A. 1886. Acari Dannosi alle Piante Coltivati. Padova, 31 pp.

Berlese, A. 1913. Acarotheca Italica. Firenze, $221 \mathrm{pp}$.

Boczek, J. 1964. Studies on mites (Acarina) living on plants in Poland. IV. Bulletin de l'Académie Polonaise des Sciences, Cl. 2 12: 365-369, 4 pls.

Bolland, II. R., Gutierrez, J. and Flechtmann, C. H. W. 1998. World Catalogue of the Spider Mite Family (Acari: Tetranychidae). Brill, Leiden, 392pp.

Boudreaux, H. B. 1956. Revision of the two-spotted spider mite (Acarina, Tetranychidae) complex, Tetranychus telarius (Linnaeus). Annals of the Entomological Society of America 49: $43-48$.

Boudreaux, H. B. and Dosse, G. 1963. Concerning the names of some common spider mites. Pp. 350-364. In: Naegele, J. A. (Ed.) Advances in Acarology, Vol. I. Comstock Publishing Associates, Ithaca, New York, 480pp.

Canestrini, G. 1889. Prospetto dell'acarofauna Italiana, Famiglia dei Tetranychini. Atti del Reale Instituto Veneto di Scienze (serie 6) 7: 491-537. 
Canestrini, G. and Fanzago, F. 1876. Nuovi acari Italiani (seconda serie). Atti della Socictà Veneto-Trentina di Scienze Naturali 5: 130-142.

Donnadieu, A. L. 1875. Recherches pour Servir à l'Histoire des Tétranyques. Société Linnéenne de Lyon, Lyon, 135pp., 12pls.

Dufour, L. 1832. Description et figure du Tetranychus lintearicus, Arachnide nouvelle de la tribu des Acarides. Annales des Sciences Naturelles 25: 276.

Dupont, L. M. 1979. On gene flow between Tetranychus urticae Koch, 1836 and Tetranychus cinnabarinus (Boisduval) Boudreaux, 1956 (Acari: Tetranychidae): synonymy between the two species. Entomologia lexperimentalis et Applicata 25: 297-303.

Düzgünes, Z. 1965.The variation in the peritreme of the genus Eotetranychus Oud. Bollettino di Zoologia Agraria e di Bachicoltura (2) 7: 15-18.

Ehara, S. 1954. Two new spider mites parasitic on Japanese conifers. Annotationes Zoologicae Japonenses 27: 102-106.

Ehara, S. 1955. On two spider mites parasitic on Japanese citrus. Annotationes Zoologicae Japonenses 28: 178-182.

Ehara, S. 1956a. Some spider mites from northern Japan. Journal of the Faculty of Science, Iokkaido University, Series 6 Zoology 12: 244-258.

Ehara, S. 1956b. Notes on some tetranychid mites of Japan. Japanese Journal of Applied Zoology 21: 139-147.

Ehara, S. 1956c. Tetranychoid mites of mulberry in Japan. Journal of the Faculty of Science, Hokkaido University, Series 6 Zoology 12: 499-510.

Ehara, S. 1957. On three spider mites of Schizotetranychus from Japan. Journal of the Faculty of Science, Hokkaido University, Series 6 Zoology 13: 15-23.

Ehara, S. 1959a. Description of a new spider mite attacking Japanese pines. Annotationes Zoologicae Japonenses 32: 97-100.

Ehara, S. 1959b. Mites of the subfamily Bryobiinae from Japan (Tetranychidae). Journal of the Faculty of Science, Hokkaido University, Series 6 Zoology 14: 185-195.

Ehara, S. 1960a. On some Japanese tetranychid mites of economic importance. Japanese Journal of Applied Entomology and Zoology 4: 234-241.

Ehara, S. 1960b. Comparative studies on the internal anatomy of three Japanese trombidiform acarinids. Journal of the Faculty of Science, Hokkaido University, Series 6 Zoology 14: $410-434$, pl. 7.

Ehara, S. 1962a. Mites of greenhouse plants in Hokkaido, with a new species of Cheyletidae. Annotationes Zoologicae Japonenses 35: 106-111.

Ehara, S. 1962b. Tetranychoid mites of conifers in Hokkaido. Journal of the Faculty of Science, Hokkaido Univiversity, Series 6 Zoology 15: 157-175.

Ehara, S. 1963a. Notes on spider mites in the collection of the Zoological Survey of India, Calcutta (Acarina: Tetranychidae). Records of the Indian Museum 59: 142-148.

Ehara, S. 1963b. A new mite of Oligonychus from rice, with notes on some Japanese spider mites (Acarina: Tetranychidae). Japanese Journal of Applied Entomology and Zoology 7: 228-231.

Ehara, S. 1964. The tetranychoid mites of Japan. Acarologia 6 (fasc. h.s.): 409-414.

Ehara, S. 1965. Two new species of Eotetranychus from Shikoku, with notes on E. kankitus Ehara (Acarina: Tetranychidae). Journal of the Faculty of Science, Hokkaido University, Series 6 Zoology 15: 618-624.

Ehara, S. 1966a. Some mites associated with plants in the State of São Paulo, Brazil, with a list of plant mites of South America. Japanese Journal of Zoology 15: 129-149.

Ehara, S. 1966b. The tetranychoid mites of Okinawa Island (Acarina: Prostigmata). Journal of the Faculty of Science, Iokkaido University, Series 6 Zoology 16: 1-22. 
Ehara, S. 1969a. Three spider mites of the genus Eotetranychus infesting fruit trees in Japan (Acarina: Tetranychidac). Applied Entomology and Zoology 4: 16-22.

Ehara, S. 1969b. Spider mites of sugar cane in eastern Asia. Journal of the Faculty of Education, Tottori University (Natural Science) 20: 19-25.

Ehara, S. 1969c. The tetranychoid mites of Taiwan (Acarina: Prostigmata). Journal of the Faculty of Education, Tottori University (Natural Science) 20: 79-103.

Ehara, S. 1970. Four species of the carpini complex of Eotetranychus in Japan (Acarina: Tetranychidae). Journal of the Faculty of Education, Tottori University (Natural Science) 21: 132-141.

Ehara, S. 1971. Description of a new species of Oligonychus, with notes on Bryobia pritchardi Rimando and Tetranycopsis borealis Ehara and Mori (Acarina: Tetranychidae). Journal of the Faculty of Education, Tottori University (Natural Science) 22: 7-11.

Ehara, S. 1973. Three species of the genus Schizotetranychus (Acarina: Tetranychidae). Annotationes Zoologicae Japonenses 46: 224-232.

Ehara, S. 1977a. A review of taxonomic studies on natural enemies of spider mites in Japan. Review of Plant Protection Research 10: 29-48. [In Japanese]

Ehara, S. 1977b. Remarks on the studies of tetranychoid mites in Japan before World War II. Pp. 241-249. In: Sasa, M. and Aoki, J. (Eds.) Contributions to Acarology in Japan. Zukan-noHokuryukan, Tokyo, xii $+602 \mathrm{pp}$. [In Japanese]

Ehara, S. 1978. A new genus and a new subgenus of spider mites from northern Japan (Acarina: Tetranychidae). Journal of the Faculty of Education, Tottori University (Natural Science) 28: 87-93.

Ehara, S. 1980. Two species of spider mites from Japan (Acarina, Tetranychidae). Annotationes Zoologicae Japonenses 53: 202-209.

Ehara, S. 1987. Two new spider mites of Eotetranychus injurious to maple in northern Japan (Acarina: Tetranychidae). Applied Entomology and Zoology 22: 624-629.

Ehara, S. 1989a. Four new species of spider mites (Acarina: Tetranychidae) from Japan. Proceedings of the Japanese Society of Systematic Zoology (40): 28-38.

Ehara, S. 1989b. Recent advances in taxonomy of Japanese tetranychoid mites. Plant Protection (Tokyo) 43: 357-361. [In Japanese]

Ehara, S. 1995. A new species of Tetranychus (Acari, Tetranychidae) from the Ryukyu Islands. Japanese Journal of Entomology 63: 229-233.

Ehara, S. 1996. Tetranychoid mites: Morphology and taxonomy. Pp. 21-81. In: Ehara, S. and Shinkaji, N. (Eds.) Principles of Plant Acarology. Zenkoku Nōson Kyōiku Kyōkai, Tokyo, viii +419 pp. [In Japanese]

Ehara, S. and Ashihara, W. 1993. Tetranychidae. Pp. 60-61, 74-77. In: Ehara, S.(Ed.) Plant Mites of Japan in Colors. Zenkoku Nōson Kyōiku Kyōkai, Tokyo, 298pp. [In Japanese]

Ehara, S. and Gotoh, T. 1987. Notes on the genus Sasanychus Ehara, new status, with description of a new species from Hokkaido (Acarina, Tetranychidae). Zoological Science 4: 375-378.

Ehara, S. and Gotoh, T. 1990. A new Tetranychus closely related to T. viennensis Zacher (Acari: Tetranychidae). International Journal of Acarology 16: 55-58.

Ehara, S. and Gotoh, T. 1991. A new species of Panonychus from dwarf bamboo in Japan (Acari: Tetranychidae). International Journal of Acarology 17: 9-12.

Ehara, S. and Gotoh, T. 1992. Descriptions of two Panonychus spider mites from Japan, with a key to species of the genus in the world (Acari: Tetranychidae). Applied Entomology and Zoology 27: 107-115.

Ehara, S. and Gotoh, T. 1993a. Description of the male of Panonychus thelytokus Ehara et Gotoh (Acari, Tetranychidae). Japanese Journal of Entomology 61: 157-160. 
Ehara, S. and Gotoh, T. 1993b. Tetranychidae. Pp. 58-59, 62-73, 90-95, 98-99, 102-105. In: Ehara, S. (Ed.) Plant Mites of Japan in Colors. Zenkoku Nōson Kyōiku Kyōkai, Tokyo, 298pp. [In Japanese]

Ehara, S. and Gotoh, T. 1996. Two new species of spider mites occurring in Japan (Acari, Tetranychidae). Journal of the Acarological Society of Japan 5: 17-25.

Ehara, S. and Gotoh, T. 1997. Eotetranychus quercifoliae, a new species of spider mite (Acari, Tetranychidae). Japanese Journal of Entomology 65: 219-223.

Ehara, S., Gotoh, T. and Nagamine, M. 1997. The occurrence of Oligonychus coffeae (Nietner) (Acari, Tetranychidac) in Okinawa Island. Plant Protection (Tokyo) 51: 25-28. [In Japanese]

Ehara, S. and Hamamura, T. 1993: Tetranychidae. Pp. 96-97, 110-111. In: Ehara, S. (Ed.) Plant Mites of Japan in Colors. Zenkoku Nōson Kyõiku Kyōkai, Tokyo, 298pp. [In Japanese]

Ehara, S, Kunimoto, Y. and Gotoh, T. 1998. An exotic spider mite found on poinsettia in Japan (Acari, Tetranychidae). Plant Protection (Tokyo) 52: 228-230. [In Japanese]

Ehara, S. and Lee, L. H. Y. 1971. Mites associated with plants in Hong Kong. Journal of the Faculty of Education, Tottori University (Natural Science) 22: 61-78.

Ehara, S. and Masaki, M. 1989. Notes on two Japanese species of Tetranychus (Acarina: Tetranychidae). Acta Arachnologica 38: 49-54.

Ehara, S. and Masaki, M. 1993. Tetranychidae. Pp. 106-109. In: Ehara, S. (Ed.) Plant Mites of Japan in Colors. Zenkoku Nōson Kyōiku Kyōkai, Tokyo, 298pp. [In Japanese]

Ehara, S. and Mori, H. 1969. A new species of the genus Tetranycopsis from Japan (Acarina: Tetranychidae). Annotationes Zoologicae Japonenses 42: 45-48.

Ehara, S. and Saito, Y. 1993. Tetranychidae. Pp. 56-57, 78-79, 84-89. In: Ehara, S. (Ed.) Plant Mites of Japan in Colors. Zenkoku Nōson Kyōiku Kyōkai, Tokyo, 298pp. [In Japanese]

Ehara, S. and Shinkaji, N. 1993. Tetranychidae. Pp. 52-55, 100-101, 110-113. In: Ehara, S. (Ed.) Plant Mites of Japan in Colors. Zenkoku Nōson Kyōiku Kyōkai, Tokyo, 298pp. [In Japanese]

Ehara, S. and Tho, Y. P. 1988. Spider mites of the Malay Peninsula (Acarina: Tetranychidae). Journal of the Faculty of Education, Tottori University (Natural Science) 37: 1-24.

Ehara, S. and Wongsiri, T. 1975. The spider mites of Thailand (Acarina: Tetranychidae). Mushi 48: 149-185.

Ehara, S. and Yamada, M. 1968. Description of a new species of Bryobia from Japan (Acarina: Tetranychidae). Annotationes Zoologicae Japonenses 41: 66-69.

Ehara, S. and Yogi, K. 1998. Discovery of Eutetranychus orientalis (Klein) (Acari, Tetranychidae) from Okinawa Island, Japan. Plant Protection (Tokyo) 52: 530-533. [In Japanese]

Ewing, II. E. 1909. New species of Acarina. Transactions of the American Entomological Society 35: $401-415$.

Eyndhoven, G. L. van 1955. Bryobia from Hedera, apple and pear (Acar., Tetran.). Notulae ad Tetranychidas 1. Entomologische Berichten 15: 340-347.

Eyndhoven, G. L. van 1956. Bryobia cristata (Dugès, 1834) and Bryobia rubrioculus (Scheuten, 1857) (Acar.) (Notulae ad Tetranychidas 3). Entomologische Berichten 16: 45-46.

Garman, P. 1940. Tetranychidae of Connecticut. Bulletin of the Connecticut Agricultural Experiment Station (418): 1-34.

Geijskes, D. C. 1939. Beiträge zur Kenntnis der europäischen Spinnmilben (Acari, Tetranychidae), mit besonderer Berücksichtigung der niederländischen Arten. Mededeelingen van de Landbouwhoogeschool te Wageningen 42 (4): 1-68.

Gomi, K. and Gotoh, T. 1996. Host plant preference and genetic compatibility of the Kanazawa spider mite, Tetranychus kanzawai Kishida (Acari: Tetranychidae). Applied Entomology and Zoology 31: 417-425. 
González, R. H. 1963. Four new mites of the genus Agistemus Summers. Acarologia 5: 342-350.

Gotoh, T. and Fhara, S. 1992. Notes on the Japanese species of the genus Panonychus (Acari, Tetranychidae). Plant Protection (Tokyo) 46: 342-347. [In Japanese]

Gotoh, T. and Noguchi, O. 1990. Developmentl success and reproductive incompatibility among populations of the European red mite, Panonychus ulmi (Acari: Tetranychidae). Experimental and Applied Acarology 10: 157-165.

Gotoh, T., Takafuji, A. and Gomi, K. 1996. Tetranychid mites of Okinawa Island (Acari: Tetranychidae). Journal of the Acarological Society of Japan 5: 89-94.

Grandjean, F. 1939. Les segments post-larvaires de l'hystérosoma chez les Oribates (Acariens). Bulletin de la Société Zoologique de France 64: 273-284.

Grandjean, F. 1947. Les Enarthronota (Acariens). 1 série. Annales des Sciences Naturelles, Zoologie 8: 213-248.

Gutierrez, J. 1985. Systematics. Pp. 75-90. In: Helle. W. and Sabelis, M. W. (Eds.) Spider Mites. Their Biology. Natural Enemies and Control, Vol. 1A. Elsevier, Amsterdam, xviii +405pp.

Hermann, J. F. 1804. Mémoire Apterologique. Strasbourg, 144pp.

Hirst, S. 1920. Revision of the English species of red spider (Genera Tetranychus and Oligonychus). Proceedings of the Zoological Society of London 1920: 49-60.

Hirst, S. 1925. Descriptions of new Acari, mainly parasitic on rodents. Proceedings of the Zoological Society of I.ondon 1924: 49-69.

Hotta, M. 1928-1929. [A study on a Japanese tea spider mite.] Transactions of the Shizuoka Prefectural Agricultural Association 32: 1-107, 33: 108-136. [In Japanese]

Jacobi, A. 1905. Eine Spinnmilbe (Tetranychus ununguis n. sp.) als Koniferenschädling. Naturwissenschaftliche Zeitschrift für Land- und Forstwirtschaft 3: 239-247.

Jeppson, L. R., Keifer, H. H. and Baker, E. W. 1975. Mites Injurious to Economic Plants. University of California Press, Berkeley, xxiv +614 pp. +63 pls.

Kishida, K. 1921. [A mite found in human urine.] Zoological Magazine (Tokyo) 33: 438-443. [In Japanese]

Kishida, K. 1927. Notes on Tetranychus kanzawai n. sp., a new tetranychid mite injurious to leaves of the mulberry tree in Japan. Zoological Magazine (Tokyo) 39: 105-107. [In Japanese]

Klein, H. Z. 1936. Contributions to the knowledge of the red spiders in Palestine. 1. The Oriental red spider, Anychus orientalis Zacher. Hadar 9: 107-112, 126-132.

Koch, C. L. 1836. Deutschlands Crustaceen, Myriapoden und Arachniden. Ein Beitrag zur Deutschen Fauna, Heft 1. Regensburg.

Lee, W.-K. and Lee, J.S. 1992. A check list and key to the tetranychoid mites (Acari: Chelicerata) of Korea. The Korean Journal of Systematic Zoology, Special Issue (3): 45-57 [In Korean with English summary]

Lee, W.-K., Lee, B.H. and Kim, B.-J. 1989. Taxonomic studies on spider mites (Tetranychidae: Acarina) of Korea. III. Spider mites parasitic on conifers. Korean Journal of Systematic Zoology 5: 13-23.

Lindquist, E. E. 1985. External anatomy. Pp. 3-28. In: Helle, W. and Sabelis, M. W. (Eds.) Spider Mites. Their Biology, Natural Enemies and Control, Vol. 1A. Elsevier, Amsterdam. $\mathrm{xviii}+405 \mathrm{pp}$.

Livshitz, I. Z. and Mitrofanov, V. 1. 1971. The mites of genus Bryobia C. L. Koch, 1836 (Acariformes, Bryobiidac). Proceedings of the State Nikita Botanical Gardens 51: 1-108. [In Russian]

Livshitz, l. Z. and Mitrofanov, V. I. 1972. To knowledge of the mites of the family Bryobiidae. Trudy Gosudarstvennogo Nikitskogo Botanicheskogo Sada 61: 5-12. [In Russian] 
Lo, P. K. C. 1969. Tetranychoid mites infesting special crops in Taiwan. Bulletin of the Sun Yat-sen Cultural Foundation (4): 43-82.

Lo, P. K. C. and Ho, C. C. 1989. The spider mite family Tetranychidae in Taiwan I. The genus Oligonychus. Journal of Taiwan Museum 42: 59-76.

Ma, E. and Yuan, I. 1965. A new species of the genus Eutetranychus. Acta Zootaxonomica Sinica 2: 247-250. [In Chinese with English summary]

Ma, E. and Yuan, I. 1982. A new genus and five new species of Tetranychidae from China (Acari: Tetranychidae). Entomotaxonomia 4: 109-114. [In Chinese with English summary]

Ma, E., Yuan, I. and Qian, Y. 1984. Spider mites. Pp. 88-163. In: Jiangxi University (Ed.) Agricultural Mites of China. Shanghai Science \& Technology Press, Shanghai, 406pp. [In Chinese]

Matsubara, T., Ohta, Y. and Ehara, S. 1992. Fine structure of female and male internal reproductive organs in a spider mite Tetranychina harti (Ewing) (Acari: Tetranychidae). Applied Entomology and Zoology 27: 65-78.

McGregor, E. A. 1914. Four new tetranychids. Annals of the Entomological Society of America 7: 354-364.

McGregor, E. A. 1916. The citrus mite named and described for the first time. Annals of the Entomological Society of America 9: 284-290.

McGregor, E. A. 1917. Descriptions of seven new species of red spiders. Proceedings of the U. S. National Museum 51: 581-590.

McGregor, E. A. 1919. The red spiders of America and a few European species likely to be introduced. Proceedings of the U. S. National Museum 56: 641-679.

McGregor, E. A. 1943. A new spider mite on citrus in southern California (Acarina: Tetranychidae). Proceedings of the Entomological Society of Washington 45: 127-128, pl. 13.

McGregor, E. A. 1950. Mites of the family Tetranychidae. American Midland Naturalist 44: 257-420.

Meyer, M. K. P. (Smith) 1974. A revision of the Tetranychidae of Africa (Acari) with a key to the genera of the world. Entomology Memoir, Department of Agricultural Technical Services, Republic of South Africa (36): 1-291.

Meyer, M. K. P. (Smith) 1987. African Tetranychidae (Acari: Prostigmata) -- With reference to the world genera. Entomology Memoir, Department of Agriculture and Water Supply, Repubublic of South Africa (69): i-iv + 1-175.

Meyer, M. K. P. and Ryke, P. A. J. 1959. A revision of the spider mites (Acarina: Tetranychidae) of South Africa with descriptions of a new genus and new species. Journal of the Entomological Society of South Africa 22: 330-366.

Miller, L. W. 1966. The tetranychid mites of Tasmania. Papers and Proceedings of the Royal Society of Tasmania 100: 53-66, pl. 1.

Mitrofanov, V. I. 1967. Tetranychoid mites of the fauna of the USSR damaging conifers. Trudy Gosudarstvennogo Nikitskogo Botanicheskogo Sada 39: 111-130. [In Russian with English summary]

Morgan, C. V. G. 1960. Anatomical characters distinguishing Bryobia arborea M. \& A. and B. praetiosa Koch (Acarina: Tetranychidae) from various areas of the world. The Canadian Entomologist 92: 595-604.

Morgan, C. V. G. and Anderson, N. H. 1957. Bryobia arborea n. sp. and morphological characters distinguishing it from $B$. praetiosa Koch (Acarina: Tetranychidae). Canadian Entomologist 89: 486-490.

Müller, O. F. 1776. Zoologiae Danicae Prodromus. Copenhagen, 282pp. 
Murray, A. 1877. Economic Entomology, Aptera. Chapman and Hall, London, 433pp.

Navajas, M., Gutierrez, J. and Gotoh, T. 1997. Convergence of molecular and morphological data reveals phylogenetic information on Tetranychus species and allows the restoration of the genus Amphitetranychus (Acari: Tetranychidae). Bulletin of Entomological Research 87: 283-288.

Nietner, J. 1861. Observations on the Enemies of the Coffee Tree in Ceylon. Ceylon, $31 \mathrm{pp}$.

Nishio, Y. 1954. Über die vier Spinnmilben an Apfelbäumen. Ōyō-Kontyū 10: 29-35. [In Japanese with German summary]

Oudemans, A. C. 1915. Notizen über Acari. Archiv für Naturgeschichte 81: 1-78.

Oudemans, A. C. 1931 a. Acarologische Aanteekeningen CVI. Entomologische Berichten 8: 189-204.

Oudemans, A. C. 1931b. Acarologische Aanteekeningen CVII. Entomologische Berichten 8: $221-236$.

Pritchard, A. E. and Baker, E. W. 1952. A guide to the spider mites of deciduous fruit trees. Hilgardia 21: 253-287.

Pritchard, A. E. and Baker, E. W. 1955. A revision of the spider mite family Tetranychidae. Pacific Coast Entomological Society Memoirs Series 2: 1-472.

Pritchard, A. E. and Keifer, H. H. 1958. Two new species of Bryobia with a revised key to the genus (Acarina: Tetranychidae). Annals of the Entomological Society of America 51: 503-506.

Quayle, J. H. 1912. Red spiders and mites of citrus trees. University of California, Agricultural Experiment Station Bulletin (234): 483-530.

Rahman, K. A. and Sapra, A. N. 1940. Mites of the family Tetranychidac from Lyallpur with descriptions of four new species. Proceedings of the Indian Academy of Sciences, Series B 11: 177-196.

Reck, H. F. 1941 a. Eine neue Schizotetranychus-Art (Tetranychidae, Acari). Soobshcheniya Akademii Nauk Gruzinskoi SSR 2: 449-453. [In German with Russian summary]

Reck, H. F. 1941 b. K ustanovleniju vidovoj prinadljeznosti pautinnogo kleshcha, vredjastsego $v$ Gruzii tsitrusovim. Soobshcheniya Akademii Nauk Gruzinskoi SSR 2: 831-835. [In Russian with English summary]

Reck, H. F. 1947. Novie vidi pautinnikh kleshchei iz Gruzii. Soobshcheniya Akademii Nauk Gruzinskoi SSR 8: 471-475. [In Russian]

Reck, H. F. 1948a. Rod Schizotetranychus (Tetranychidae, Acari) po materialam iz Gruzii. Soobshcheniya Akademii Nauk Gruzinskoi SSR 9: 369-376. [In Russian]

Reck, H. F. 1848b. Opisanie vidov roda Schizotetranychus (Träg.) iz Gruzii. Soobshchenniya Akademii Nauk Gruzinskoi SSR 9: 445-452. [In Russian]

Reck, H. F. 1950. Materiali k faune pautinnikh kleshchei Gruzii (Tetranychidae, Acarina). Trudy Instituta Zoologii Akademii Nauk Gruzinskoi SSR 9: 117-134. [In Russian]

Reck, H. F. 1952. O nekotorikh osnovakh klassifikatsii tetranikovikh kleshchei. Soobshcheniya Akademii Nauk Gruzinskoi SSR 13: 419-425. [In Russian]

Reck, H. F. 1956. Novie vidi tetranichovych kleshchei iz vostocnoj Gruzii. Trudy Instituta Zoologii Akademii Nauk Gruzinskoi SSR 15: 5-28. [In Russian]

Reck, H. F. 1959. Opredelitel Tetranikovikh Kleshchei. Fauna Zakaukazia. Akademii Nauk Gruzinskoi SSR., Tbilisi, 152pp. [In Russian]

Reeves, R. M. 1963. Tetranychidae infesting woody plants in New York State, and a life history study of the elm spider mite Eotetranychus matthyssei n. sp. Cornell University Agricultural Experiment Station Memoir (380): 1-99.

Riley, C. V. 1890. The six-spotted mite of the orange (Tetranychus 6-maculatus, n. sp.). Insect Life 
2: 225-226.

Rimando, L. C. 1962. The tetranychoid mites of the Philippines. University of the Philippines, College of Agriculture, Technical Bulletin 11: 1-52.

Rimando, L. C. 1966. A new subfamily of spider mites with the description of a new genus and two species (Acarina: Tetranychidae: Aponychinae). The Philippine Agriculturist 50: 105-113.

Rimando, L. C. 1968. The genus Aponychus (Tetranychidae, Acarina). The Philippine Entomologist 1: 6-10.

Rota, P. 1962. Osservazioni sugli Acari Tetranychidi dannosi alle piante coltivate ed ornamentali in Italia. Studi del Gruppo di Lavoro del C.N.R. per le Virosi: LVII. Bollettino di Zoologia Agraria e di Bachicoltura, Serie 2 4: 31-136, pls.1-5.

Ryu, M. O. and Ehara, S. 1995. Two spider mites from Korea (Acari, Tetranychidae). Journal of the Acarological Society of Japan 4: 15-20.

Saito, Y. 1990. Two new spider mite species of the Schizotetranychus celarius complex (Acari: Tetranychidae). Applied Entomology and Zoology 35: 389-396.

Saito, Y. 1993. Tetranychidae. Pp. 80-83. In: Ehara, S. (Ed.) Plant Mites of Japan in Colors. Zenkoku Nōson Kyōiku Kyōkai, Tokyo, 298pp. [In Japanese]

Scheuten, E. 1857. Einiges über Milben. Archiv für Naturgeschichte 23: 104-112, pls. 6-7.

Sepasgosarian, H. 1955. Morphologie und Biologie der gelben Apfelspinnmilbe Eotetranychus pomi n. sp. (Acar., Tetranychidae). Dissertation. Landwirtschaftlichen Ilochschule Hohenheim, Stuttgart-Hohenheim. 67pp.

Summers, F. M. 1960. Several stigmaeid mites formerly included in Mediolala redescribed in Zetzellia Ouds, and Agistemus, new genus. Proceedings of the Entomological Society of Washington 62: 233-247.

Targioni Tozzetti, A. 1878. Relazione intorno ai lavori della Stazione di lintomologia Agraria di Firenze per l'anno 1876. Acaridei. Annales Agronomiques 1: 242-275.

Trägårdh, I. 1915. Bidrag till kännedomen om spinnvalstren (Tetranychus Duf.). Meddelanden frản Centralanstalten för Försöksväsendet på Jordbruksområdet. Entomologiska Avdelningen 54: 259-310.

Tseng, Y. H. 1990. A monograph of the mite family Tetranychidae (Acarina: Trombidiformes) from Taiwan. Taiwan Museum Special Publication Series (9): 1-224.

Tuttle, D. M. and E. W. Baker 1968. Spider Mites of Southwestern United States and a Revision of the Family Tetranychidae. University of Arizona Press, Tucson, viii +143pp.

Tuttle, D. M., Baker, E. W. and Abbatiello, M. J. 1976. Spider mites of Mexico (Acari: Tetranychidae). International Journal of Acarology 2: 1-102.

Vacante, V. 1985. Prima raccolta di acari Tetranichidi in Sicilia (1). Phytophaga 1 (1983): 41-114, pls. $1-17$.

Wainstein, B. A. 1960. Tetranychoid mites of Kazakhstan (with revision of the family). Trudy Naucno-Issledovatelskogo Instituta Zashiti Rastenij 5: 1-276. [in Russian]

Wang, H. 1980. Notes on the genus Eotetranychus in China with descriptions of four new species (Acarina: Tetranychidae). Acta Entomologica Sinica 23: 216-223. [In Chinese with English summary]

Wang, H. 1981. Acariformes: Tetranychoidea. Economic Insect Fauna of China, Fasc. 23. Science Press, Beijing, v 150 pp., 4 pls. [In Chinese]

Yago, M. and Furukori, N. 1937. Studies on the pear tetranychid mite, Tetranychus sp. Bulletin of the Shizuoka-ken Agricultural Experiment Station (43): 1-30, pls. 1-3. [In Japanese]

Yokoyama, K. 1929. New Textbook of Sericultural Insect Pests. Meibundo, Tokyo, 569pp. [In Japanese] 
Yokoyama, K. 1932. New tetranychid mites attacking the mulberry leaf. Contribution I. Bionomics and external structures of the Tetranychus suginamensis n. sp. Bulletin of the Imperial Sericultural Experiment Station (Tokyo) 8: 229-287, pls. 23, 24. [In Japanese with English summary]

Yokoyama, K. and Ishii, G. 1934. Tetranychid mites attacking the mulberry leaf. Contribution II. External structures and bionomics of Panonychus mori Kishida. Bulletin of the Imperial Sericultural Experiment Station (Tokyo) 8: 425-454, pl. 32. [In Japanese with English summary]

Zacher, F. 1913. Untersuchungen über Spinnmilben. Mitteilungen aus der Kaiserlichen Biologischen Anstalt für Land. und Forstwirtschaft 14: 37-41.

Zacher, F. 1915. Neue und wenig bekannte Spinnmilben. Zeitschrift für angewandte Entomologie 2: 181-187.

Zacher, F. 1920. Vorläufige Diagnosen einem neue Spinnmilben. 1p., Berlin. [Mimeograph]

Zacher, F. 1949. Arachnoidea, Spinnentiere. Pp. 139-207. In: Sorauer, P. (Ed.) Handbuch der Pflanzenkrankheiten, Band 4. 5 Aufl., 1 Lief. Paul Parey, Berlin, viii +449pp. 
